


\section{WIKI ARCHITECTURE}

Is open source architecture possible?

Edward G. Solodukhin

A thesis submitted to the Faculty of Graduate Studies and Research in partial fulfillment of the requirements for the degree of

Master of Architecture

M.Arch (Professional)

Carleton University, Ottawa, Canada

May 22nd, 2009

(C) Edward Solodukhin 2009 
Library and Archives

Canada

Published Heritage Branch

395 Wellington Street

Ottawa ON K1A ON4

Canada
Bibliotheqque et

Archives Canada

Direction du

Patrimoine de l'édition

395 , rue Wellington

Ottawa ON K1A ON4

Canada
Your file Votre référence

ISBN: 978-0-494-60284-3

Our file Notre référence

ISBN: 978-0-494-60284-3
NOTICE:

The author has granted a nonexclusive license allowing Library and Archives Canada to reproduce, publish, archive, preserve, conserve, communicate to the public by telecommunication or on the Internet, loan, distribute and sell theses worldwide, for commercial or noncommercial purposes, in microform, paper, electronic and/or any other formats.

The author retains copyright ownership and moral rights in this thesis. Neither the thesis nor substantial extracts from it may be printed or otherwise reproduced without the author's permission.
AVIS:

L'auteur a accordé une licence non exclusive permettant à la Bibliothèque et Archives Canada de reproduire, publier, archiver, sauvegarder, conserver, transmettre au public par télécommunication ou par l'Internet, prêter, distribuer et vendre des thèses partout dans le monde, à des fins commerciales ou autres, sur support microforme, papier, électronique et/ou autres formats.

L'auteur conserve la propriété du droit d'auteur et des droits moraux qui protège cette thèse. $\mathrm{Ni}$ la thèse ni des extraits substantiels de celle-ci ne doivent être imprimés ou autrement reproduits sans son autorisation.
In compliance with the Canadian Privacy Act some supporting forms may have been removed from this thesis.

While these forms may be included in the document page count, their removal does not represent any loss of content from the thesis.
Conformément à la loi canadienne sur la protection de la vie privée, quelques formulaires secondaires ont été enlevés de cette thèse.

Bien que ces formulaires aient inclus dans la pagination, il n'y aura aucun contenu manquant. 
Friday, May 22, 2009 | Project's Internet page: http://arch1k.wikidot.com/

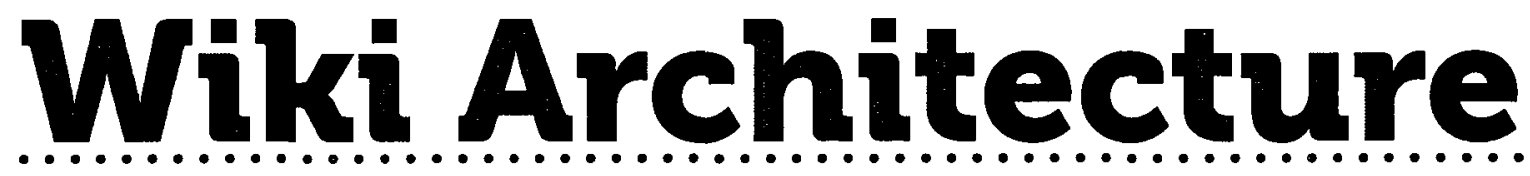

Is open source architecture possible?

» To ignore heterarchy is to avoid self-reflexivity!

ßy: Edward G. Solodukhin

Advisor: Stephen Fai • The Azrieli School of Architecture and Urbanism 


\section{$0 »$ Abstract}

The term open source was introduced in 1998 to describe a non-linear, self-organizing and heterarchical model intended specifically for the conduct of software development. Since then, it has revolutionized the private and commercial sectors of networking, and introduced many quality software alternatives.

Today this phenomenon transcends to other disciplines. Its most prominent features include abilities to encourage and sustain learning and innovation. While making knowledge accessible, it inspires large devoted and active communities. These benefits are compelling and empowering, and have attracted industries other than the realm of software development.

This project applies the open source approach to the field of architectural design. "As both a process and product(building) of open source development, this project lends support to an argument for viewing open source conceptually and concretely as a source of social innovation in learning environments."

Ultimately, the premise of this thesis is not an opinion or a critique of open source but rather a desire to explore whether the symbiosis of open source and architecture is possible, and more importantly, what consequences does it entail.

1 Doubleday, Nancy. "Adaptive Co-management and the Learning that Leads to Social Innovation", in Open Source Business Resource, is. September 2008: Social Innovation, http://www.osbr.ca/ojs/index.php/osbr/article/view/702/670 (accessed April 14 ${ }^{\text {th }}$, 2009). - Taken from an article reviewing the Wiki Architecture project. 


\section{1»Acknowledgements}

Many thanks to my advisor Stephen Fai, who helped me find direction and offered valuable feedback on the work in progress. Thanks to my dear family, friends and colleagues for advice, motivation and moral support. Thanks to Alisa Niakhai for always being near, for editorial help, and a great deal of encouragement. Thanks to Maximilian Hugh with whom I discussed and explored these topics. Last but not least, I thank the people that contributed and helped make the Wiki Architecture experiment possible. 


\section{2»Table of contents}

0» Abstract

.2

1» Acknowledgements.

3

2» Table of contents..............................................................

3» List of illustrations.............................................................

4» Introduction: note to the reader..................................9

5» Open Source ………………………………………...12

6» Authorship and architecture......................................16

6.1) Morphology and history of the authorship paradigm............................16

6.2) Shaping forces in the evolution of architectural authorship .............24

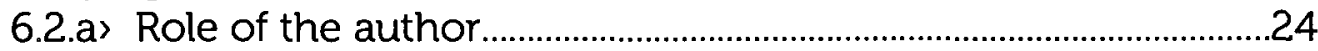

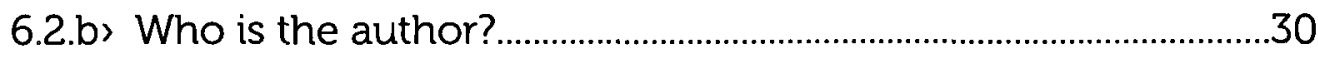

6.2.c) Technology and Generative techniques........................................33

6.2.d) Professional survivalism...................................................................38

6.2.d.1> Legitimacy of architectural profession................................39

6.2.d.2) Naming and Branding. Legitimizing? (optional)................40

6.2.d.3> Is architectural profession necessary?..................................41

6.2.d.4> Could open source preserve architectural profession?. .41

6.3) Forgetting craftsmanship. .46 


\section{7» Open source and the resurrection of}

craftsmanship.

7.1) Professional community.

7.2) Quality and evolution ....................................................................................5

7.3) Hierarchy and heterarchy ...........................................................................52

7.3.a) The problem with hierarchy ………………...................................52

7.3.b> Introducing heterarchy ………………………………………….........55

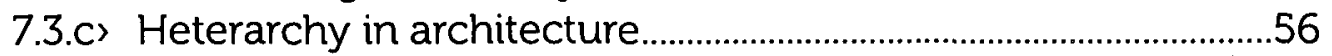

8» The Wiki Architecture experiment: applying the open source methods...................................................60

8.1) The procedural and the anatomical approaches......................................60

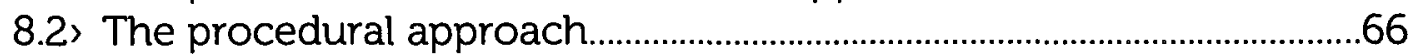

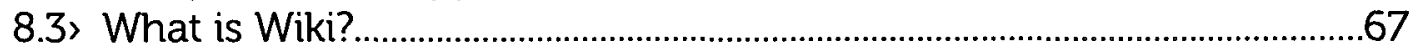

8.4) Description of the Wiki Architecture's assembly......................................69

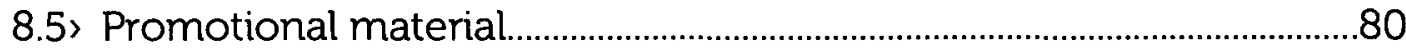

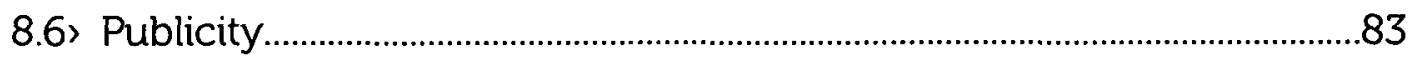

9» The White House Redux project................................86

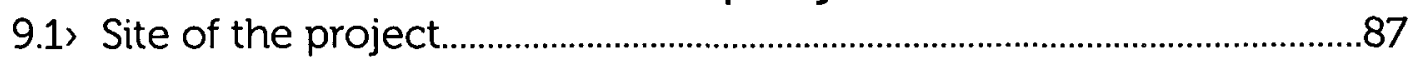

9.2) Personal submission: the anatomical approach..........................................89

9.2.a) Concept...............................................................................................93

9.2.b> Design Process.............................................................................................

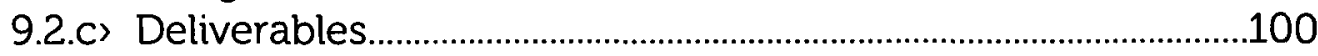

9.3. Glimpse at the output of collaborative work in progress....................107

10» Conclusion .........................................................................112

11» Bibliography $\ldots \ldots \ldots \ldots \ldots \ldots \ldots \ldots \ldots \ldots \ldots \ldots \ldots \ldots \ldots \ldots \ldots \ldots \ldots \ldots \ldots \ldots \ldots \ldots \ldots . .118$ 


\section{3»List of illustrations}

Illustration 1: Alberti's etching.

Illustration 2:Prices's Network analysis

27

Illustration 3: ShoP Architect's process: from design to buildng..............................29

Illustration 4: Unidirectional hierarchy ............................................................................54

Illustration 5: Bidirectional Heterarchy ............................................................................54

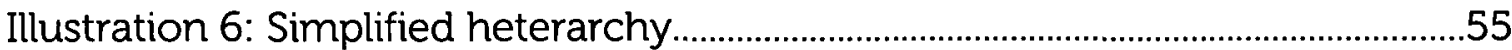

Illustration 7: Simplified anarchy diagram.......................................................................55

Illustration 8: Centre Georges Pompidou.............................................................................63

Illustration 9: Fun Palace

Illustration 10: New Babylon...........................................................................................64

Illustration 11: Buckminster Fuller standing inside modular steel framework...65

Illustration 12: Default Wiki Architecture user interface...............................................72

Illustration 13: Current Wiki Architecture user interface .............................................73

Illustration 14: Wiki Architecture "About" section (part 1 of 2)...................................74

Illustration 15: Wiki Architecture "About" section (part 2 of 2)...................................75

Illustration 16: Wiki Architecture "Playground" section (part 1 of 3)........................76

Illustration 17: Wiki Architecture "Playground" section (part 2 of 3).......................77

Illustration 18: Wiki Architecture "Playground" section (part 3 of 3).......................78

Illustration 19: Wiki Architecture "Forum" section............................................................79

Illustration 20: Wiki Architecture promotional poster (eMail version)....................81 
Illustration 21: Wiki Architecture promotional poster No.1 (version for print). . 82 Illustration 22: Wiki Architecture promotional poster No.2 (version for print)..82 Illustration 23: White House Situation. Rendering of a three dimensional model..

Illustration 24: Kit of parts designed to initialize the collaborative process at Wiki Architecture, 1 of 5 .90

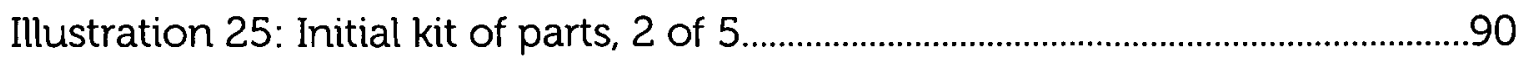

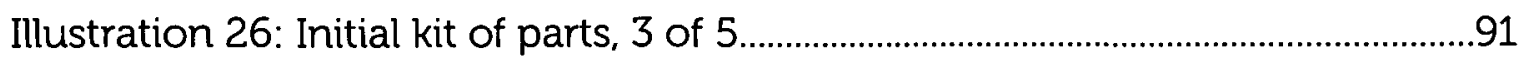

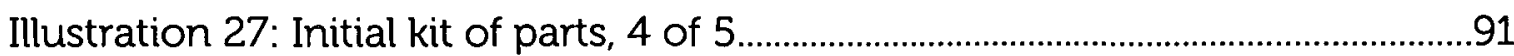

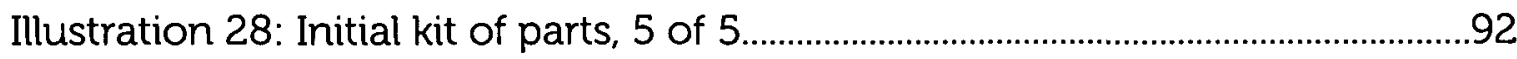

Illustration 29: Personal submission process, 1 of 10

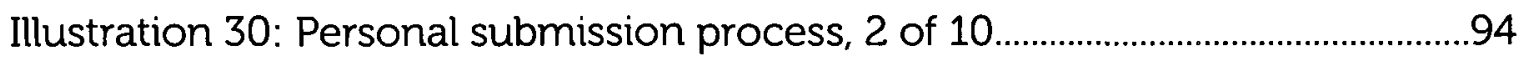

Illustration 31: Personal submission process, 3 of 10................................................95

Illustration 32: Personal submission process, 4 of 10

Illustration 33: Personal submission process, 5 of 10..................................................

Illustration 34: Personal submission process, 6 of 10

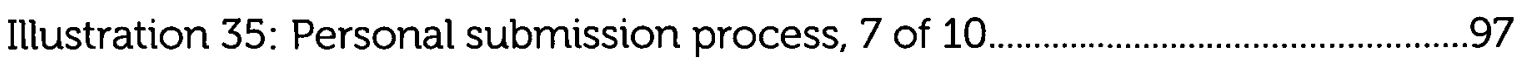

Illustration 36: Personal submission process, 8 of 10.................................................97

Illustration 37: Personal submission process, 9 of 10.................................................99

Illustration 38: Personal submission process, 10 of 10

Illustration 39: White House Redux - Personal Submission, No. 1 of 6 Accompanying Text.

Illustration 40: White House Redux - Personal Submission, No. 2 of 6 - Design Process. 102

Illustration 41: White House Redux - Personal Submission, No. 3 of 6 - Design Process. 
Illustration 42: White House Redux - Personal Submission, No. 4 of 6 Perspective View.

Illustration 43: White House Redux - Personal Submission, No. 5 of 6 South/Front Elevation

Illustration 44: White House Redux - Personal Submission, No. 6 of 6 - East, North, West Elevations. 106

Illustration 45: First addition to the kit-of-parts library, made by the wiki user "smantzer". 108

Illustration 46: Concept by the user "smantzer", 1 of 4...............................................108

Illustration 47: Concept by the user "smantzer", 2 of 4..........................................108

Illustration 48: Concept by the user "smantzer", 3 of 4 .............................................108

Illustration 49: Concept by the user "smantzer", 4 of 4.............................................108

Illustration 50: Most current concept design of the White house, last edited by "Slychimera", 1 of 2.

Illustration 51: Most current concept design of the White house, last edited by "Slychimera", 2 of 2

Illustration 52: Wiki Architecture visitors overview, from April 2nd, 2008 to May 3rd, 2009 


\section{4»Introduction: note to the reader}

$\left\{\begin{array}{l}\text { Background and reference information composed in order to render a clear context } \\ \text { in which the experiment took place }\end{array}\right.$

The term Open Source was first coined in 1998 by Eric Steven Raymond in his essay The Cathedral and the Bazaar, although in one form or another this methodology has existed even earlier. He described a nonlinear, self-organizing, and heterarchical model that was appropriate in the conduct of software development. Over the last ten to fifteen years this approach have proven to be very successful on many fronts. Thousands of open source practices sprouted earning a great deal of popularity and wide critical acclaim. It is often regarded as a superior business model in comparison to its proprietary counterparts, due to its inherent attainability, customizability, expert base, and the openness of source itself.

Open source has revolutionized the private and commercial ends of networking, and introduced quality software alternatives that loom jeopardy on the stance of many of the industry's giants. Patrons of the movement often take pride in greatly progressing the state of software technologies, while making them affordable and attainable for everyone. In many cases the original definition of open source has been only loosely followed. Many practices exist within various degrees of the "openness" spectrum, while taking advantage of the aspects that suit best their professional profile. Today many enjoy the freely available quality tools, while the conscription rates keep continuously growing, including both the end users and those involved in the process. 
A simple developmental model makes the open source possible. It bestows involved results, and creates unorthodox cultural bonds and has an impact on cultural ethics. Herein, a question arises: can one study this phenomenon and employ its prominent concepts in other fields, such as architecture?

\section{步}

The philosophy of open source is not a novelty. Freedoms to speak, contribute, and participate are facets of every public institution. Cultural centres, public schools, swimming pools, city squares, beaches and other entities, all promote egalitarian use of their property. A road is yet another great example of a medium offering every freedom of use, while employing nondiscriminative laws to optimize commute.

Analogously, the concept of source code $e^{2}$ is readily found in the everyday practice of architecture in forms of drawings, agendas, documentation, ideas, specifications, and material libraries. However, none of the above, with the seldom exception of $i d e a s$, are freely redistributable, publicized, or allow for criticism and input akin to what an open source model offers. The architectural practice, today, is skewed towards personal benefit and gratification of individual architects. Thus, while the laws protect creative property, they are constricting and oppose to collaborative creativity, which has the capacity to advance the architectural theory and practice more rapidly.

I would argue that architectural practices could benefit greatly from the transparency of process that the open source module boasts. If the design processes, planning, and the general production sequence from design to construction were observable, architects would be able to take on a pedagogical role in society. This is especially important in the architectural profession, where training requires both faculties theoretical and practical. It is, also, important to look at the paradigm of authorship, its evolving history, its definitions, and ways in which it is affected today by the new concepts introduced with the emergence of

2 N.B. For a definition of open source continue to chapter "5" Open Source", on page 12 
open source. Who are the authors in this new system and what are they authoring? What legitimizes the architectural profession and will open source strengthen or undo its credibility? We will identify the technologies that make the open source community possible; how the communication within this environment is powered, and what laws and values govern this interaction. Namely, we will conduct an experiment utilizing the wiki software, which lends its name to this research paper, and happens to be one of the most common tools used to facilitate the open source collaboration.

Finally, the experiment will attempt to simulate the conditions of a an architectural project with the help of open source technologies and methods. We will look and discuss the results as well as conclude about the prominence of such experiment. 
$\{$ Definition and essential information about the open source phenomenon including \{ historical data, methodologies, philosophy, and milestones. \}

Today majority of the software available on the market is offered in a compiled ready-to-use form. Processed through a compiler program, the source code has been translated into a machine-readable binary code, which a computer can later comprehend and execute ${ }^{3}$. Consequently, most consumers possess the only compiled version of a program, which does not include the original program code. Without having such source code, it is practically impossible to change the programs' compiled variant or conceive of how the programmer designed and developed the application. Machine language with which the consumer ends up with is complex and takes immense efforts to interpret, let alone be translated back into an editable source code - a process that is called reverse engineering.

The source code itself is a collection of human readable commands and routines which, collectively make up a computer program with all its functions and features. Such code is the blueprint of computer programming, and, thus, most commercial software manufacturers prefer to retain and protect it from being discovered and copied by other firms, or individuals. Monopoly over a specific program code gives software firms a crucial competitive advantage. Since its competitors can not easily access the code, they can not study and modify it and, therefore, are unable to offer a software program that matches or exceed the quality and characteristics of a given product, without having to write the binary code from scratch. This proprietary mode of software development is also known as closed source. It is cherished and

3 'What does open source mean?', retrieved from How Stuff Works website, http://computer.howstuffworks.com/question435.htm (Accesed April $2^{\text {nd }}$, 2009) 
utilized by such software giants as Microsoft, Adobe, Apple Macintosh, Yahoo!, and hundreds of others.

There is, however, an alternative way of developing software known as the open source. As the name implies, the source code is made available with each piece of software respectively for everybody to be revised, replicated, corrected or customized. ${ }^{4}$ Program developers do not withhold the source code, but release it on its own or together with each compiled version of a program.

Proponents of the open source movement argue that such approach allows for "...better quality, higher reliability, more flexibility, lower cost, and an end to predatory vendor lock-in..." ${ }^{\text {in a }}$ long run. In fact, over the past twenty five years open source movement has encouraged unique collaborations across the globe, incited technological advances and produced remarkable software programs. ${ }^{6}$ Among the most well-known are Apache, some variants of Unix, many distributions of Linux, Mozilla, BIND, Sendmail and hundreds more.

To be considered open source, a software program must be published in accordance with a license that conforms to a number of criteria developed by the Open Source Initiative. These ten principles are captured in the Open Source Definition ${ }^{7}$ document and have become a standard in the software industry. First three criteria - free redistribution, source code, and derived work - specify that any software program, should be available for sale or distributed freely, in conjunction with its source code, by any party. Additionally, the license must explicitly allow customization of the original source code and free distribution of the derived projects and their program codes under a similar license. The Definition prohibits any type of discrimination whether against persons and groups or fields of endeavor. Also, In order to

4 Deek P. Fadi and James A. McHugh. Open Source: technology and policy, (New York: Cambridge University Press,2008), 1.

5 Open Source Initiative, http://www.opensource.org/ (Accessed April 15 ${ }^{\text {th }}$, 2009)

6 Deek P. Fadi and James A. McHugh. Open Source: technology and policy, (New York: Cambridge University Press,2008), ix.

7 Open Source Initiative. "The Open Source Definition", http://www.opensource.org/docs/osd (Accessed April 15 ${ }^{\text {th }}, 2008$ ) 
avoid license traps, which may inhibit code reuse and redistribution, it stipulates that the license has to be technology-neutral and not specific to a project. Finally, the license must be universally applied to everyone, who uses a program, and must not impose restrictions on any other software. This type of legal framework is often dubbed "copyleft" as opposed to "copyright", which gives the creator/owner of the work exclusive rights "...to produce and reproduce the work in question or to permit anyone else to do so." Instead of releasing the software into the public domain - where it can be shared but also runs a risk of being copyrighted - the "copyleft" protects the programs from being converted into proprietary software and ensures that "...all copies of all versions are free software".

As one can see, these two methodologies of software development are at the opposite ends of the spectrum. ${ }^{10}$ Not only do they differ in their organization and business models, their conceptual underpinnings are also fundamentally conflicting. As suggested by the prominent advocate of the open source movement, Eric S. Raymond, in his essay "The Cathedral and the Bazaar", the closed source and the open source represent "...two fundamentally different development styles, the 'cathedral' model [...and the] 'Bazaar' model of the Linux world." The cathedral metaphor describes the model of development, which is hierarchical in its structure and centralized around an authoritative figure that has the exclusive power to delegate the tasks, select the inputs and control the outputs. Conversely, the bazaar model is a heterarchical system, which embraces the community and allows for voluntary participation, contribution, exchange of skills and selection of tasks. ${ }^{11}$ In the world of software development, the former stands as a traditional model with small development groups, fewer release cycles, little flexibility and limited amount of external feedback ${ }^{12}$. The latter is embodied by the open

8 Canadian Intellectual Property Office, A Guide to Copyrights, http://www.ic.gc.ca/eic/site/cipointernetinternetopic.nsf/eng/wroo506.html\#nol (Accessed April 16 ${ }^{\text {th }}$, 2009)

9 GNU Operation System. "Public domain software", http://www.gnu.org/philosophy/categories.html\#PublicDomainSoftware (Accessed April 15 ${ }^{\text {th }}$, 2009)

10 Deek P. Fadi and James A. McHugh. Open Source: technology and policy (New York: Cambridge University Press, 2008), 2.

11 Weber Steve, The success of Open Source (USA: Harvard University Press, 2004): 62

12 Fink, Martin. The business and economics of Linux and Open Source, (New Jersey: Prentice Hall PTR, 2003), 139. 
source with its frequent releases, instant feedback, unmatched flexibility, and collaborative and self-healing nature.

It should be also noted, that Raymons's essay became a groundbreaking publication, which introduced popularly the concept of open source. Today it remains instrumental to the understanding of theory and practice of the open source movement. It has also been credited with playing a big role in persuading of the proprietary software giant Netscape to make the source code of its token Web browser public and initiate the Mozilla project ${ }^{13}$, which, as a result, became a stepping stone for the open source movement.

13 Jones, Steve. Encyclopedia of New Media (New York: The Moschovitis Group, 2003):60 


\section{6»Authorship and architecture}

Authorship, in all fields, is the act of assuming a degree of responsibility over a given entity while claiming the source of its originality ${ }^{14}$. This is a rather limiting definition for a matter subjected to variableness, throughout the history, due to contextualization, jurisprudence and ethics. In architecture, this discourse over authorship has numerously challenged the core legitimacy and purposefulness of the profession. By modernity the degree of architect's expressiveness and level of involvement were questioned by unsettling disputations over professional intent and style. This uncertainty has been consistently exacerbated by the accompanying advancements in both building and generative technologies which further shift the paradigm confining architectural responsibility.

\subsection{Morphology and history of the authorship paradigm}

The subject of authorship is most central to the architectural discipline as it alludes to a semantic crossover between the built as identified and the architect as it's identifier. One is often "...prompted by the widespread habit of referring to buildings in the possessive [voice] 'Alberti's Tempio Malatestiano', 'Le Corbusier's Chapel at Ronchamp'..."15. Such semantic structure traces back to the Renaissance or even the antiquity according to the editors of Architecture and Authorship. It is ambiguous whether it is the critics or the architects

14 The American Heritage Dictionary of the English Language, 4th edition (Boston: Houghton Mifflin Company, 2007).

15 Introduction to Architecture and Authorship, by Anstey, Tim, Grillner, Katja, and Rolf Hughes (London: Black Dog Publishing Limited and the authors, 2007), 7. 
themselves that make the habit of ascribing individuals' names to buildings; as well as, in case architects are authors, "exactly what are they authoring?" 16.

From the fifteenth century Architects began identifying themselves using argumentation centred around the issue of authorship and intentions behind their work as if to market an architectural brand. For instance, in 1570 Andrea Palladio published the I Quattro Libri dell'Architettura(The Four Books of Architecture), which thoroughly described his attitude towards architecture and architectural style using illustrations (Illustration 1) and prose that heavily drew from the work of Vitruvius. ${ }^{17}$ Later, Vincenzo Scamozzi printed a six books treatise titled $L^{\prime}$ idea della architettura universale(the groundrules of art of building) in 1615 which became widely popular for its classification of column orders. From there on, many others followed in this pursuit to propagate their visions of the architectural proper. ${ }^{18}$ In fact Architectural theory ${ }^{19}$ mentions a count of 117 of such treatises, written as of today. It is as though each of these architects has made an attempt to author a style or an ideology - often delivered in a competitive fashion.

16 Introduction to Architecture and Authorship, by Anstey, Tim, Grillner, Katja, and Rolf Hughes (London: Black Dog Publishing Limited and the authors, 2007), 6.

17 Evers, Prof. Dr. Bernd, Christof Thoenes. Architectural theory (Berlin: Taschen, 2003), 110.

18 Evers, Prof. Dr. Bernd, Christof Thoenes. Architectural theory (Berlin: Taschen, 2003), 10.

19 Evers, Prof. Dr. Bernd, Christof Thoenes. Architectural theory (Berlin: Taschen, 2003), no. 


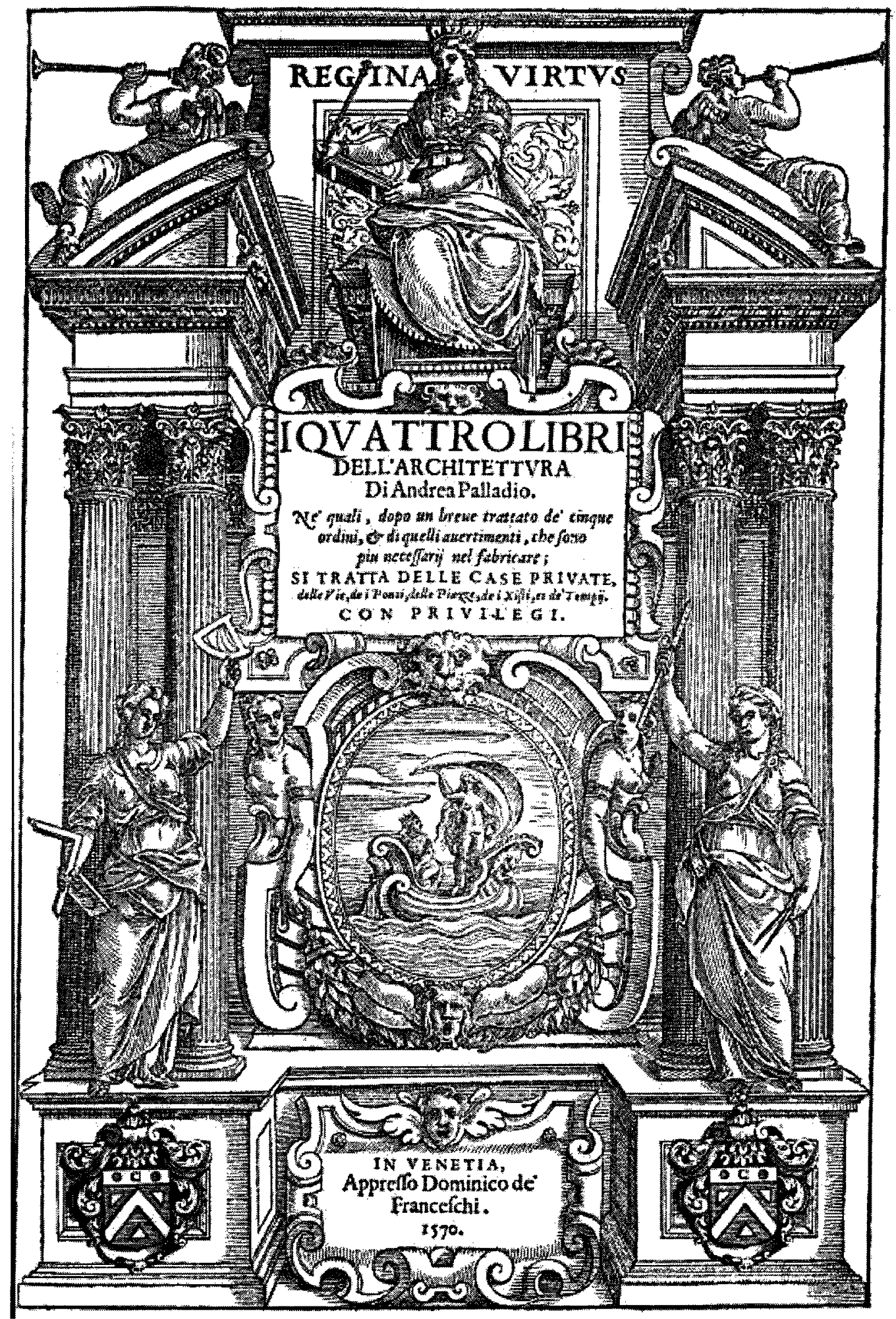

Illustration 1: Alberti's etching

Source: Palladio, Andrea,Erik Forssman. Iquattro libri dell'architettura (Georg Olms Verlag, 1979), 1. 
Working primarily with texts both Roland Barthes in "The Death of the Author", 1967, and Michael Foucault in "What is an Author?", 1969, explored the stipulation between authors and their work. As a result, both concluded that authorship is a social construct.

For his argumentation Barthes used Balzac's novel "Sarrasine”, in which he vividly portrayed the emotions of a castrate disguised as a woman. This example demonstrated that a writer possess none or only a limited insight into the subject matters that they address. To Barthes this observation rendered the act of writing as a creation of an empty semantic "tissue of quotations" that merely borrows from other texts and creative mediums. ${ }^{20} \mathrm{He}$ elaborated even further stating that "...all texts are made of fragments of other texts and are thus necessarily intertextual..." 21 and the reproduction of text is "...a premutative operation of the 'deconstruction-reconstruction' of former texts..." ${ }^{\text {22 }}$. In the Poststructuralist era this concept was adapted and further investigated by the Bulgarian-French philosopher, literary critic, and psychoanalyst Julia Kristeva. In her book Semeiotikè of 1969 she was first to introduce the term of intertectuality to describe this phenomenon.

Barthes described the idea of an author as a modern construct that banks on the "prestige of the individual"23 - which denotes the recognition of a person with their own thoughts and opinions. For Barthes, it is due to a "capitalist ideology"24 that one claims their work as original in order to be an author, and thus must deny their relying on any "point of origin" 25 . It is, however, an impossibility as those points ultimately comprise the "centers of culture"26. Moreover, Barthes notes that "the writer can bring to light only signs without signifieds"27, where as the reader is the one for whom the writing is aggregated and who embodies and

20 Barthes, Roland. The Death of the Author (1968).

21 Martin, Louis. "Transpositions: On the Intellectual Origins of Tschumi's Architectural Theory, in Assemblage, No. 11, (Cambridge: MIT Press, 1990), 29.

22 Martin, Louis. "Transpositions: On the Intellectual Origins of Tschumi's Architectural Theory, in Assemblage, No. 11, (Cambridge: MIT Press, 1990), 29.

23 Barthes, Roland. The Death of the Author (1968).

24 Barthes, Roland. The Death of the Author (1968).

25 Barthes, Roland. The Death of the Author (1968).

26 Barthes, Roland. The Death of the Author (1968).

27 Lavers, Annette. Roland Barthes, Structuralism and After: Structuralism and After (London: Taylor \& Francis, 1982), 93. 
interprets it while giving it meaning. As a result, to Barthes the writer is pragmatic while the reader acts as the true author. In translation to architectural terms this may imply that the critics as well as the inhibitors through their dialogue and interaction with architecture inadvertently take part in its authoring.

Foucault acknowledged Bathes' notion that that the author is dead, but was more interested in the meaning of such postulation. He noted that scrutinizing the semantic link between the author and text would reveal plenty about the legitimizing structures behind every discipline. ${ }^{28}$ His interpretation of an author was similar to what is know in the film studies as the auteur theory. It was coined earlier by Andrew Sarris ${ }^{29}$ in 1962 and was heavily advocated even earlier by the film critic François Truffaut in the $1950 \mathrm{~s}^{30}$ According to this theory an author is one that leaves a distinctive personal touch in every creative output that they become associated with. In film an example of author is Orson Welles, Alfred Hitchcock, or Joseph Frank "Buster" Keaton. While, the films which the directed, produced or stared in are were carried out by a large crew of people, their auteur presence becomes most prominent. As a result, a Hitchcockian film wouldn't necessarily be directed by Hitchcock but would clearly exhibit his emblematic themes and styles. ${ }^{31}$ In architecture such auteur quality can be attributed to Carlo Scarpa, Louis Isadore Kahn, or Ludwig Mies van der Rohe, whose idealogical and stylistic features are often reproduced.

Foucault speaks of the author as an "author-function" ${ }^{32}$ rather then a title. It is a gauge of quality against which other works may be contrasted. An author can be a historical persona tokened as a reference. Such is the God of Hermes Trismegistus for instance, which is generalized today as a literary fabrication of cultural significance and a mark in history. ${ }^{33}$

28 Foucault, Michel. What is an Author?, translation Donald F. Bouchard and Sherry Simon, In Language, Counter-Memory, Practice (New York: Cornell University Press, 1977), 124-127.

29 Caughie, John. Theories of authorship: a reader (London: Routledge, 1985), 22.

30 Bennett, Andrew. The Author (London: Routledge, 2005), 106.

31 Pramaggiore, Maria, Tom Wallis. Film: A Critical Introduction (China: Laurence King Publishing, 2005), 372.

32 Foucault, Michel. What is an author?, in Textual Strategies: Perspectives in Post-structuralist Criticism, by Josué V. Harari(London: Routledge, 1980), 148.

33 Foucault, Michel. What is an author?, in Textual Strategies: Perspectives in Post-structuralist Criticism, by Josué V. Harari(London: Routledge, 1980), 147. 
Finally Foucault believed that "the function of an author is to characterize the existence, circulation and operation of certain discourses within societies." ${ }^{34}$ This observation is especially distinctive in the architectural theory, where every discourse is accompanied by names of individuals that stand behind vital concepts and ideologies.<smiles>[V]</smiles>

Definitions of authorship are diverse. In history, they have fluctuated throughout the cultural, dialectical, personal and jurisprudential realms. However, contemporary theorist Seán Bruke points out that these definitions may be easier to grasp if categorized as either imitative or inspirational. Examples of such classifications are evident across a number of disciplines. The only exception to the rule is in the literary studies where, an acclaimed author may be likened to either a prophet(imitative) or a visionary(inspirational), depending on the degree to which one shapes the content they deliver.

In Classical philosophy the discourse over authorship is generally summarized as the concept of memesis - or literally the act of mimicry and imitation. For instance, in Platonism every creation is assumed to be a copy of a divine prototype. In Aristotelianism the maker is one that merely purifies an entity from a raw material.

In the medieval period the concept of authorship was significantly different from its modern counterpart. Although, A. J. Minnis in "Medieval Theory of Authorship ${ }^{35}$ identifies the medieval term auctor as being most closely related to the present notion of authorship. He explains that "auctor was conceived as a writer and an authority, who ultimately takes his authority from God"36. Hence, the auctor had unquestionable credibility and was to be respected and trusted. However, their job was far from inventive, as they were to "...establish

34 Foucault, Michel. What is an Author?, translation Donald F. Bouchard and Sherry Simon, In Language, Counter-Memory, Practice (New York: Cornell University Press, 1977), 124.

35 A.J. Minnis, Medieval Theory of Authorship: Scholastic Literary Attitudes in the Later Middle Ages (London: Scolar Press, 1984).

36 Bennett, Andrew. The Author (London: Routledge, 2005), 39. 
the founding rules and principles..." ${ }^{37}$ by interpreting old scripts. Moreover, in contrast to the romantic and modern understandings of the author as an individual with subjective and unique intentions, the identity of the medieval auctor was of a modest importance and in practice often remained anonymous outside of their communities ${ }^{38}$. Consequently, in western culture until the eighteenth century, an author lacked the ability to create out of nothing $\left(\right.$ creatio ex nibilo ${ }^{39}$ ) and instead simply acted as a conduit of divine designs to the audience ${ }^{40}$.

Historically, a progression is evident, which starts from the imitative stage in antiquity, to inspirational throughout the Middle Ages, and eventually leading into what may be described as the generative phase today. In the latter the source of creativity becomes implicit to the author, and the ownership over work is implied. Beginning in the early nineteenth century, the author figure had progressively liberated from being defined by the church and state, and became a commodity of a free trade ${ }^{41}$. With this token, authorship became an intellectual property, branded by the authors personality, defended by the law, and bound with the paradigm of originality. Now human fathers work, not God.

However, it would be a mistake to assume that the concept of an author as an absolute generator of original work surfaced only in the modern period. Essayist Dr. Robert Meagher, in his publication Technê, explains the word Architect from the etymological point of view in order to reveal its age and immediate accountability for shaping of the modern authorship paradigm.

The term architect is ancient Greek in origin and is comprised of two roots, where technê stands for "making" or "creating", and archai translates as origin or foundational principles - "prima

37 Bennett, Andrew. The Author (London: Routledge, 2005), 40.

38 Bennett, Andrew. The Author (London: Routledge, 2005), 40-41.

39 Introduction to Architecture and Authorship, by Anstey, Tim, Grillner, Katja, and Rolf Hughes (London: Black Dog Publishing Limited and the authors, 2007), 8.

40 Introduction to Architecture and Authorship, by Anstey, Tim, Grillner, Katja, and Rolf Hughes (London: Black Dog Publishing Limited and the authors, 2007), 8.

41 Introduction to Architecture and Authorship, by Anstey, Tim, Grillner, Katja, and Rolf Hughes (London: Black Dog Publishing Limited and the authors, 2007), 6. 
elementa". Accordingly, architecton or architect literally entails a "master-producer". ${ }^{42}$ However, Meagher draws an important distinction between the two concepts - making and creating, as they describe differently the meaning of technê. The former meaning is characteristic of the pre-modern period, and is synonymous with the act of producing, or distilling a familiar entity. The latter term is synonymous with magic or birthing of a novelty. Like Aristotle, Meagher believes that when humans gaze at a tree they are merely inspired to associate it with shelter, fuel, food, and tools. ${ }^{43} \mathrm{He}$ states that in practise, until modernity, only God was attributed with the ability to create out of void. However, Greek mythology addresses this subject otherwise.

Titan Prometheus was a rebel son of Lapetus of the Oceanids. According to the myth, Prometheus commiserated with people because he considered the world they lived in to be crude and unsuitable. He thieved fire from Zeus and passed it to humans - gifting them with the principles of technê: faculties of conceiving and creating from nothing. ${ }^{44}$ At this point humans became capable of shaping the surroundings for their personal comfort. Shortly, Zeus ordered a punishment for these actions - humans were deprived of fire and given mortality, while Prometheus was incarcerated for the period of three million years. This story, despite being a piece of fictional poetry, documents that the topic of originality and authorship was already present in the ancient theoretical discourse. Inevitably the term architecture has always incorporated these conflicting yet fundamental concepts in its etymological roots.

42 Meagher, E. Robert. 'Techne',in Perspecta 24: The Yale Architectural Journal (New York: Rizzoli, 1988), 158164.

43 Meagher, E. Robert. 'Techne',in Perspecta 24: The Yale Architectural Journal (New York: Rizzoli, 1988), 158164.

44 Meagher, E. Robert. 'Techne',in Perspecta 24: The Yale Architectural Journal (New York: Rizzoli, 1988), 158164 . 


\section{2) Shaping forces in the evolution of architectural authorship.}

According to Architecture and Authorship there are four general areas of critical treatment that consistently reshape the contemporary model of architectural authorship: (a) the role of the architect, (b) who is to act on that role? (c) accommodation of technology and generative techniques, (d) the issues of professional survivalism.

\section{2.as Role of the author}

Modern discussion over the nature of architectural actions dates back to a time in the end of World War II when the housing crisis in the, then, demolished Europe planted the notion of viewing architecture as a service rather than an act of expression, intention, or style. By diverting the critical attention away from the physical form a search began for a set of criteria that would help resolve a more pragmatic problem of housing shortages.

At first, a number of quick fix solutions emerged, amongst which were the British New Towns - designed in hopes to give life to a "New Britain". ${ }^{45}$ These were industrial satellite towns intended primarily to accommodate the working class. Inspired by the amalgamation of the "... intellectual imperatives of Fabianism and the fading dreams of the Garden City movement" ${ }^{\mathbf{4}}$ they promised a more gradual approach to urbanization, in contrast to the forced mode akin of the earlier Garden Cities. However, despite the optimism of the reviving modernism, the new constructs were largely uninspiring. Not only, were they constructed using the least of means ${ }^{47}$, but were also criticized for merely casting in concrete the "...diagrammatic versions of pre-war urban visions..."48. They still ignored the nuances of the physical surroundings and local traditions in Europe while attempting a calculated remedy against the effects of WWII.

45 Curtis, J. R. William. Modern Architecture Since 1900, third edition(London: Phaidon Press Limited, 2003), 529.

46 Curtis, J. R. William. Modern Architecture Since 1900, third edition(London: Phaidon Press Limited, 2003), 529.

47 Curtis, J. R. William. Modern Architecture Since 19oo, third edition(London: Phaidon Press Limited, 2003), 529.

48 Curtis, J. R. William. Modern Architecture Since 1900, third edition(London: Phaidon Press Limited, 2003), 471. 
Nevertheless, by the early 1950 s, the haste of reconstruction finally met critical response, and the discourse began to move away from, what Paul Verilio called strategic "grand narratives" of urbanism towards more tactical and per-case tailored solutions. As a result, new practises sprouted that focused primarily on context, amongst which were Cedric Price, Richard Rogers', Norma Foster's, and SHoP.

This migration of architectural actions was congruent with both: the aftermath of industrialization in Europe, which altered and introduced new professions; as well as a shift in the paradigm of architectural authorship - away from being viewed as an artistic endeavour. In order to understand how architecture earned this bohemian quality, and why it had to be reevaluated, Tim Anstey in Architecture and Rhetoric calls to look at the ostensibly empirical link between buildings and architects as it was depicted by Leon Battista Alberti.

Alberti, in De re aedificatoria (On the art of building) explains buildings through their phenomenological ability to affect an audience by exhibiting a "divine sense of beauty"50. Such effect is the result of proper compositional proportions, as Astey argues, and thus it is largely the responsibility of an architect. However, the association between the built and the architect is indirect. What architect conveys through graphic representation later undergoes a process of interpretation by commissioners and various third party trades. Such interpretations are prone to diversion from the inexplicable intent of the architect. For that reason, Alberti introduced the notion of assessing architecture through the architects' rhetoric in addition to reviewing the design realization. With this token Alberti placed the emphasis on the ideological intent, and appointed the architect as its author. Consequently, only by 1950s has this formula evolved to recognize that the architectural action is greatly dependant on context.

As mentioned above, Cedric Price played an important role in this evolution. His work challenged the significance of traditional architectural drawing as the primary means of

49 Verilio, Paul, The Overexposed City, 1984, in Architecture Theory Since 1968, by K. Michael Hays (London: MIT Press, 2000), 549.

50 Alberti, Leon Battista. On the Art of Buildung in Ten Books, $I X$, 10, By Joseph Rykwert, Robert Tavernor, Neil Leach trans. (London: MIT Press, 1988), 315. 
representation and the status of visual imagery at large as a defining component for a project. Price often preferred diagrammatic representation over orthographic projections, because it allowed to incorporate areas that were neglected in the traditional drawings. Building's functions, circulation and other dynamic aspects of the its daily performance could now be represented and thus accounted for in the design. As a result, Price shifted the architectural field of action to include the building's behaviour and away from dealing with elements that are subjected to builders interpretation. For instance, Price's Network Analysis drawing maps a"...web of statutory and contractual forces that condition the decision making process necessary before the construction..." ${ }^{51}$ (Illustration 2).

51 Anstey, Tim. 'Architecture and Rhetoric: Persuasion, Context, Action' in Architecture and Authorship ed. by Anstey, Tim, Grillner, Katja, and Rolf Hughes (London: Black Dog Publishing Limited and the authors, 2007), 22. 


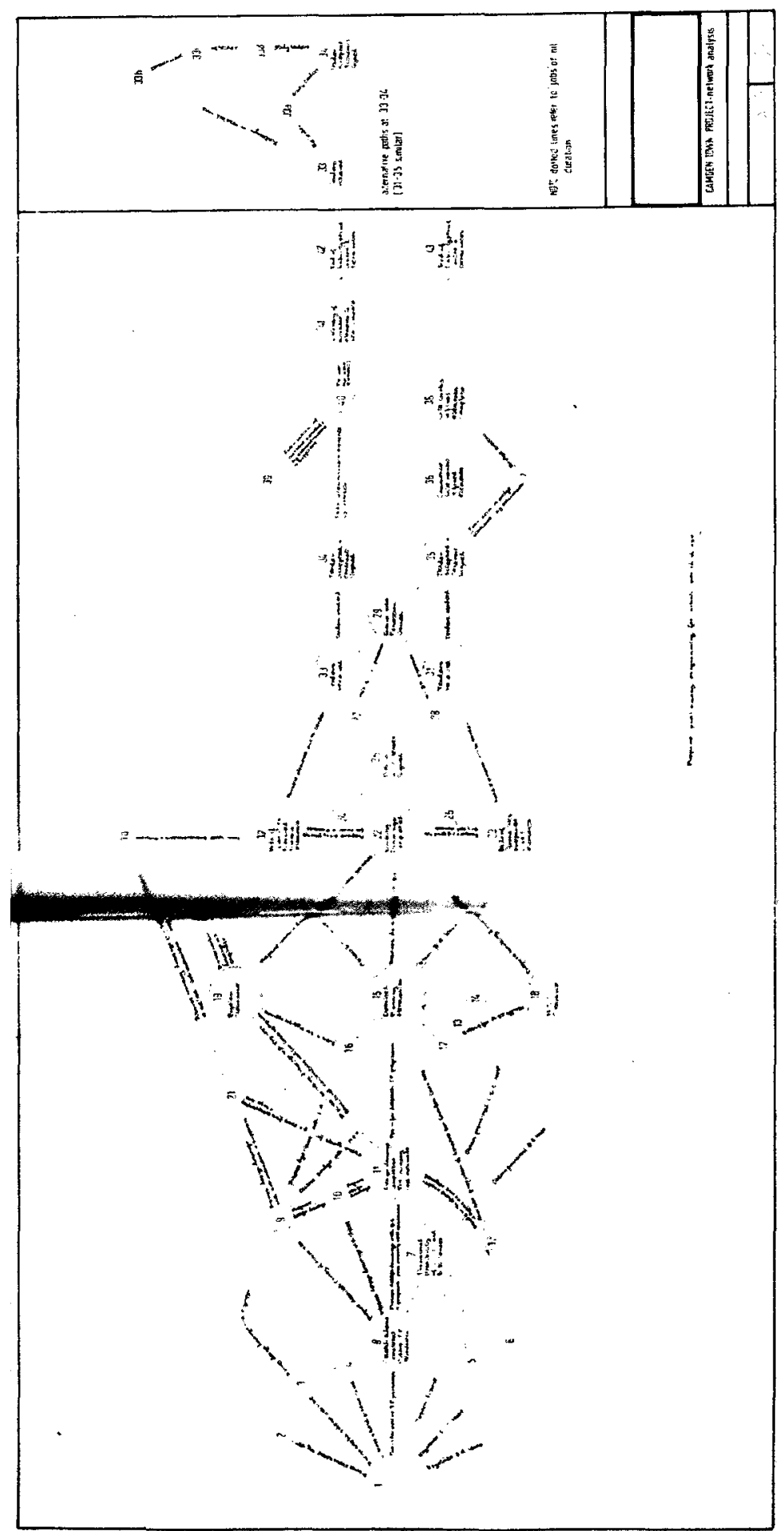

Illustration 2:Prices's Network analysis

Source: Anstey, Tim. 'Architecture and Rhetoric: Persuasion, Context, Action' in Architecture and Authorship ed. by Anstey, Tim, Grillner, Katja, and Rolf Hughes (London: Black Dog Publishing Limited and the authors, 2007), 22. 
As opposed to Price, who questioned the reach of architects' authority, New York based firm SHoP Architects is set to regain absolute authority over the architectural production and thus eliminate the gap between intention and realization. Their approach is twofold: at the "level of the project", and "level of building". The former relies on advanced technologically aided visualization techniques in order to explicate a clear architectural intent, and thus get close to eliminating interpretation of the design by other trades. At building's level, SHoP attempts at "closing off the rhetorical dimension of architectural drawing" 52 in order to completely avoid interpretation. They employ computer generated full scale templates in their building production, which allow the architect to directly control a machine that would produce precise parts. These may be assembled only in one way to construct a building, as it was done in such projects as the Dunescape for the PS1 museum,the Camera Obscura for Mitchell Park, and the 290 Mulberry Street project in Manhattan (Illustration 3). However, despite the authoritarian approach to architectural production, SHoP Architects still acknowledge the significance multifaceted aspects of the context.

52 Anstey, Tim. 'Architecture and Rhetoric: Persuasion, Context, Action' in Architecture and Authorship ed. by Anstey, Tim, Grillner, Katja, and Rolf Hughes (London: Black Dog Publishing Limited and the authors, 2007), 29. 


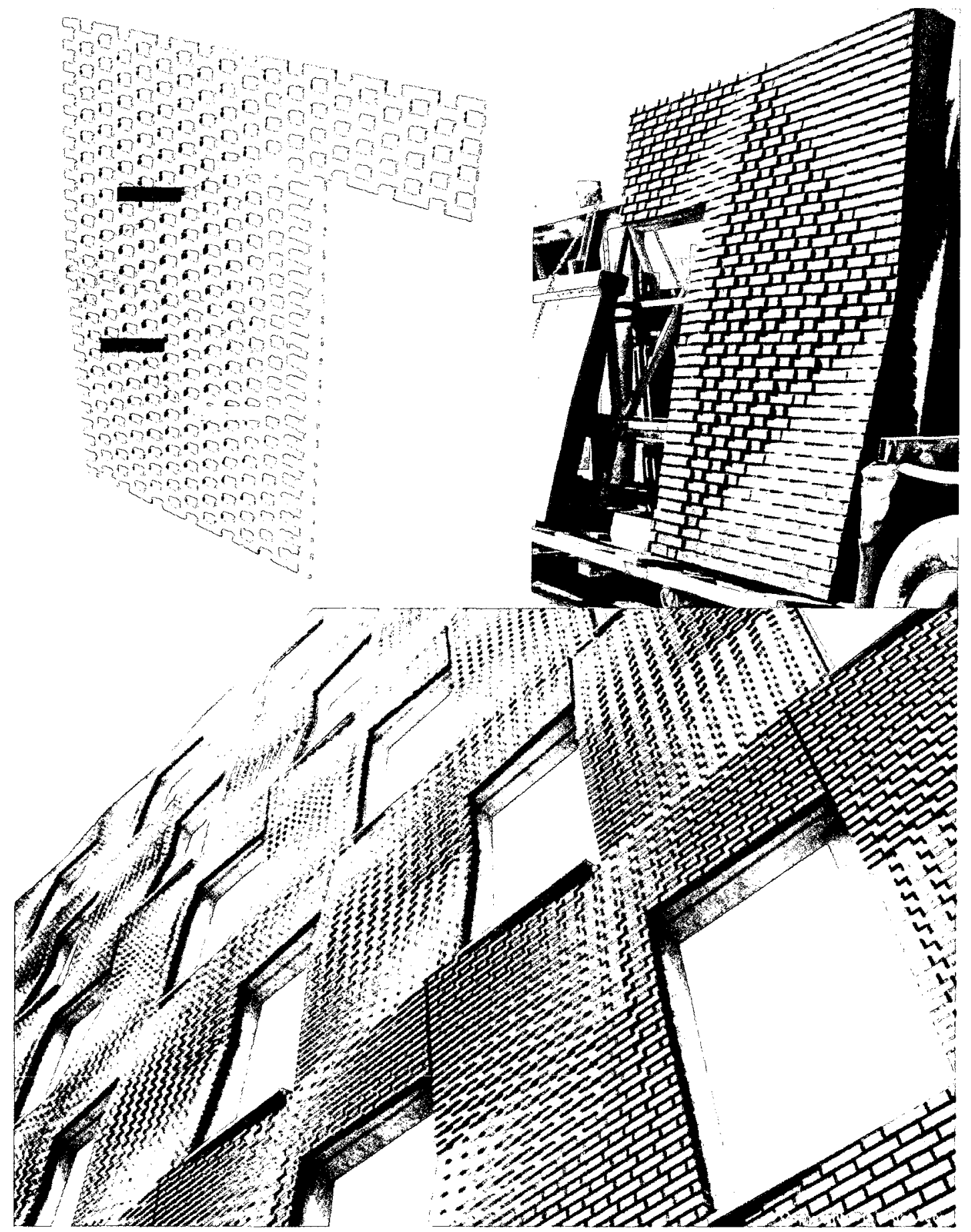

Illustration 3: ShoP Architect's process: from design to buildng

Source: Fano, David. 'SHoP Architects 290 Mulberry Project', in Design Reform (May 24 ${ }^{\text {th }}, 2008$ ),

http://designreform.net/2008/05/24/shop-architects-29o-mulberry-project/ (accessed March 25th, 2009) 


\section{2.b) Who is the author?}

The emphasis on context had also triggered a vast discourse over the possibility of a new architecture that would respond dynamically to the inhabitant's needs. Since architecture was to be environmentally specific and architects were no longer its branding artists, why couldn't the environment, with the help of a professional of course, produce its own architecture, should a demand arise. At the time such conception was explored by the architects Cedric Price, and Archigram, and later has grown to influence the work of such as Richard Rogers, Renzo Piano, Buckminster Fuller, Rem Koolhaas, and others. At its core, it was an ideology that marked the beginning of a perpetual discourse over whom should the architectural authoring belong to.

Price's Fun Palace, of 1961, was a result of a collaboration with a theatrical director Joan Littlewood. ${ }^{53}$ It boasted an open program "...comprised of various moveable entertainment facilities..." ${ }^{n 4}$, and revolved around the idea that a proper combination of technology and planning could give the inhabitant an unprecedented control over their environment. The Fun Palace was not to be a sentimental monument, but a kit of parts intended for serving people $e^{55}$. This approach questioned the role of the architect as a designer of spaces - since these were up to the dwellers' interpretation at the Fun Palace - and in return allocated the authoring of infrastructure ${ }^{56}$ as a new field of action. Moreover, Price fully rejected the concept of an architect as an authoring figure and, at the time, dismissed his role as an architect altogether preferring the title of 'anti-architect'. ${ }^{5758}$ This disassociation from the profession not only allowed for a greater freedom to choose between architectural responsibilities and

53 Price, Cedric. Arata Isozaki, Patrick Keiller, Hans-Ulrich Obrist. RE: CP (Basel: Birkhauser Verlag AG, 2003), 28.

54 Price, Cedric. Arata Isozaki, Patrick Keiller, Hans-Ulrich Obrist. RE: $C P$ (Basel: Birkhauser Verlag AG, 2003), 28.

55 Banham, Reyner. A Critic Writes: Selected Essays by Reyner Banham, selected by Mary Banham, Paul Barker, Sutherland Lyall, Cedric Price (Los Angeles: University of California Press, 1997), 107.

56 Price, Cedric. Arata Isozaki, Patrick Keiller, Hans-Ulrich Obrist. RE: CP (Basel: Birkhauser Verlag AG, 2003), 28-33.

57 Introduction to Architecture and Authorship, by Anstey, Tim, Grillner, Katja, and Rolf Hughes (London: Black Dog Publishing Limited and the authors, 2007), 10.

58 Mathews, Stanley. "Cedric Price as Anti-architect", Architecture and Authorship, ed. by Anstey, Tim, Grillner, Katja, and Rolf Hughes (London: Black Dog Publishing Limited and the authors, 2007), 142. 
accommodated the desire to seek new ways of intervention into the built environment, but also allowed for attribution of other trades involved(builders, draftsmen, craftsmen, engineers, etc.) - also labelling them as fundamental authors in the making of architecture.

The deliberate diffusion of the traditional author figure and a desire to embrace creative pluralism had also become the founding principles behind the Archigram group in the 1960s.

Their popular, anti-monumental, and anti-heroic approach to architecture, fascination with infrastructure, and rejection of many ideological underpinnings of the era of the grands constructeurs $^{59}$, closely resembled the stance of Cedric Price. However, in contrast to Price's theory it was not the context that provided the primary guidelines for a building project, to Archigram, but a synthesis achieved through a dialogue between architecture, technology and inhabitants. They believed in the potential of a building to become an interactive part of infrastructure that would mold and accommodate all the hedonistic possibilities of the modern consumerism ${ }^{60}$. This is the avenue that later gained great attention, with the coming of the Internet age, from such theoreticians as Lebbeus Woods in the Berlin Free-Zone ${ }^{6 l}$ project, and Hakim Bey in his Temporary Autonomous Zone $(T A Z)^{62}$.

Unfortunately, Archigram's avant-garde designs were subjected to the bias of the group's visual objectification of technology, and a brief affiliation with the Futurist movement, which was noted in the Archigram no.1..$^{63}$ Archigram, and later Superstudio and Archizoom, printed glossy pamphlets of Pop imagery that employed every technique of the corporate advertisement in order to communicate their rather surreal beliefs. This was different in Price's stance as he would even "...refuse to release any pictures of what the FP[Fun Palace] will

59 Curtis, J. R. William. Modern Architecture Since 1900, third edition(London: Phaidon Press Limited, 2003), 536.

6o Curtis, J. R. William. Modern Architecture Since 1900, third edition(London: Phaidon Press Limited, 2003), 539 .

61 Woods, Lebbeus. "The Question of Space" Technoscience and Cyberculture. Eds. Stanley Aronowitz, B. Martinsons, and M. Menser. (New York: Routledge, 1996), 279-292.

62 Bey, Hakim. The Temporary Autonomous Zone: Ontological Anarchy, Poetic Terrorism. http://www.to.or.at/hakimbey/taz/taz.htm (Accesed February 24th 2009)

63 Sadler, Simon, Archigram (Group). Archigram: Architecture Without Architecture, (Cambridge, MA: MIT Press, 2005), 43. 
actually look like..." ${ }^{64}$. His passion was not superficial but ideological in nature. However, visual seduction does not necessarily render Archigram's designs completely superfluous. What was a visual fetish at the time - today, may have matured into a level that is to some degree technologically plausible and most importantly desirable. Their visuals may be interpreted as diagrammatic representations of the complex social and economic structures that began forming since the beginning of the Internet age.

It is also important to note that the rejection of a grand narrative in architecture by the infrastructuralists Price and Archigram coincided with the postmodernist rejection of the onesize-fits-all application of philosophy. However, not everyone followed this trend at the time. In comparison, Team X placed the emphasis on author's identity and also proposed a definitive vision of architecture in an attempt to, once again, dialectically legitimize it. Team $\mathrm{X}$ offered a strategic and result oriented approach, while Price and Archigram sought to provide tools and tactics for the conceiving of design. While both Price and Archigram wanted to utilize, adopt and play with technology, Team X attempted to tame and "humanize" it ${ }^{65}$. They did not want it to have a heavy formal impact on architecture and inhabitants' lives. Conversely, to Archigram the purpose of technology was both to serve people and to become a plaything that was allowed to evolve and synthesize with its environment. Appearance of technology was in fact desirable.

This discern with the agents that shape architecture was the basis for the anti-heroic architecture. It was not heroic in the sense that it was not revolutionary, but in the sense that the author behind the ongoing evolution was finally unimportant. In support of this theory, Catherine Ingraham, in her Architecture, Animal, Human, adds that a "Change, in biology, is never heroic (a point of arrival) or even anti-heroic (a shared, interstitial, boundary line)"66, as neither any change in nature; it simply occurs.

64 Banham, Reyner. A Critic Writes: Selected Essays by Reyner Banham, selected by Mary Banham, Paul Barker, Sutherland Lyall, Cedric Price (Los Angeles: University of California Press, 1997), 107.

65 Curtis, J. R. William. Modern Architecture Since 1900, third edition(London: Phaidon Press Limited, 2003), 536

66 Ingraham, Catherine. Architecture, Animal, Human: The Asymmetrical Condition (New York: Routledge, 2006), 27. 
Finally, There is an obvious similitude between the anti-heroism of the 1960 s and the the modus operandi of the earlier mentioned open source movement.

\section{2.c) Technology and Generative techniques}

While talking about the evolution of architectural actions one can not avoid the topic of technology. It has always been a challenging factor that evolved because of-, in accord with-, and in precedence to the changes in architectural methods and theory. However, this symbiosis has only gained its full momentum in the beginning of the 1960s, when technology reached a grater degree of automation, which in turn provided the way for the concept of self-organizing systems to surface. This advancement, challenged the authorship paradigm once again, and expanded the architectural discourse to include the notion of generative design. It became both a blow to traditional notions in architecture and a stepping stone for new practises to come. Emerging practises employed generative design techniques and often utilized cutting edge technologies in order to gather, aggregate, and analyze architectural data. These methods were fundamentally different from the traditional - authoritarian design routines of architecture. They outsourced the creative processes away from the architect and into: either the hands of rule based systems and the probabilities associated with them; or the algorithmically perfect machine processing. As a result, the centrality of architectural intentions, and the definition of poetics came under question, once again.

A research paper presented at the 2004 Futureground conference held at Monash University of Melbourne explicates well the meaning behind the generative design:

"Generative systems offer a methodology and philosophy that view the world in terms of dynamic processes and their outcomes. In the terminology of Thomas Kuhn (Kuhn 1996), it offers a paradigm shift for the process of design and the expression of that process. For designers, it involves a reconsideration of the static artefact and the actions that manipulate it. Conceptualisation shifts from the primacy of objects to envisaging interacting components, systems and processes, which in turn generate new artefacts, with special properties..." ${ }^{\text {6r }}$

67 McCormack, Jon, Alan Dorin, Troy Innocent. 'Generative Design: a paradigm for design research' in Redmond, J. et. al. (eds) Proceedings of Futureground, vol.2, is.1, (Caulfield East Vic: Monash University, Faculty of Art \& Design, 2004), 1. 
Amongst the practises involved in the generative field were those that looked at the generative approach as a way to instrumentalize the design process. Christopher Alexander, for instance, was an architectural theoretician and practitioner, as well as ,a significant contributor to the field of artificial intelligence of computer sciences. In his book The Timeless Way of Building, of 1979, he offered a systematic and efficient strategy for conceiving architecture. His criteria were gathered around identifying and analyzing prominent patterns found in traditional building construction. He believed “...that successful architecture is essentially the application of design patterns that have been around for thousands of years, albeit not recorded"68 ${ }^{\text {. He }}$ said:

"There is one timeless way of building. It is a thousand years old, and the same today as it has ever been. The great traditional buildings of the past, the villages and tents and temples in which man feels at home, have always been made by people who were very close to the center of this way. It is not possible to make great buildings, or great towns, beautiful places, places where you feel yourself, places where you feel alive, except by following this way. And, as you will see, this way will lead anyone who looks for it to buildings which are themselves as ancient in their form, as the trees and hills, and as our faces are." ${ }^{19}$

Alexander's approach was somewhat similar to the work of Aldo Rossi, in the way that it looked to establish typographical data based on repeating patterns found in historical buildings. Rossi, believed that he could take advantage of this information in his designs, because he speculated that traditional architecture had established an architectural language that is culturally interpreted and embedded in the collective memory of a city. ${ }^{70}$

Likewise, Alexander was analyzing the European medieval cities in order to find the unwritten local features and patterns, which made those visually engaging and harmonious. Throughout this process he stumbled upon the concept of generative grammar. It was originally introduced in the 1950s by a theoretician and a linguist Noam Chomsky in the transformational grammar theory. It attempted to explain the relationship between human mind and the syntax of

68 Laplante, Phillip A., Colin J. Neill. AntiPatterns: identification, refactoring, and management, (Malvern: Auerbach Publications, 2006), 2.

69 Alexander, Christopher. The Timeless Way of Building, (New York: Oxford University Press, 1979), 7. 70 Canniffe,Eamonn. "Neo-Rationalism: Aldo Rossi and the rediscovery of typology", in The Politics of the Piazza, (Manchester: Ashgate Publishing Ltd., 2008), 221-236. 
natural languages. The assumption was that mind is a rule system independent of language that holds "....very complex sets of interacting rules [which]...are actually there, in peoples" heads and are responsible for the way the environment gets its structure ${ }^{\prime m 71}$. Alexander translated this theory into architecture - declaring that environmental design is also a construct, in which analysis of syntactic elements could be used to predict, or generate a greater more complex system. He was famous for his speculation that in architecture:

"Each pattern describes a problem which occurs over and over again in our environment, and then describes the core of the solution to that problem, in such a way that you can use this solution a million times over, without ever doing it the same way twice." ${ }^{2}$

Architecture was now a scalable construct - a fractal - a language composed of a limited amount of patterns and rules, with the understanding of which any architecture could be generated.

This was a dangerous speculation; one that could undermine the architectural profession as a whole. If, Alexander's observations were true, and a sound architecture could be generated upon a given set of criteria, any empowered individual could take on the task of building, and thusly rendering the need for a professional obsolete. However, together with Sarah Ishikawa and Murray Silverstain, Alexander was comfortable with the idea of empowering any person, because they belied that only the dwellers themselves knew enough about what dwellings they required. ${ }^{73}$

\section{$\frac{17}{17}$}

In addition to Alexander, Architecture and Authorship mentions Ernst Neufert, Peter Eisenman, and Lionel March as people that approached the concept of self-organizing systems in form of instrumental theories. Lionel March introduced the The System Aesthetics

71 Portugali, Juval. "Inter-representation Networks and cognitive mapping" in The construction of cognitive maps, ed. Juval Portugali, (Netherlands: Springer, 1996) 32-33.

72 Laplante, Phillip A., Colin J. Neill. AntiPatterns: identification, refactoring, and management, (Malvern: Auerbach Publications, 2006), 3.

73 Holm, Ivar. Ideas and beliefs in architecture and industrial design: how attitudes, orientations, and underlying assumptions shape built environment, Ph.D. Thesis, (Oslo: Oslo School of Architecture and Design, 2006), 481. 
methodology, in which an underlying structure of any design could be found. With this token he expected to deal away with the human aspect of the architectural profession; such things as: "intuitive skill", "confusion", "sophistical sciences", "individual hunches", "court jesters and acrobats", "private pranks", "pricey prima-donnas", "hallucinations", "extravagant and empty images", "individual expression", and "personal prejudice". ${ }^{74} \mathrm{He}$ thought that the artistic intuition was unaccountable for its actions and not on par with the rhythms in which society developed in the time of post-war reconstruction.

Alexander, Lionel and other "instrumentalists" had attempted to modify the process of architectural design by introducing scientific and mathematical methods. Ironically these attempts were frighteningly reminiscent of the Modernist ideology of social engineering, which only half a century ago was heavily criticized for its totalitarian and uninspiring nature.

It should also be pointed out that not all generative practises employed various technologies or were instrumental. Peter Eisenman, in fact was so opposed to the use of technology and especially its instrumental approach that decided to write a professorial thesis that would refute Alexander's fascination with computer systems. Eisenman's approach was more formalist in nature. He developed a system of rules that would help an architect to deform originally perfect cubic solids into forms that would respond to the conditions of their environment and the inhibitor's needs. This way the architect still renamed in charge of the grater project, but had more systematic methodology and modern tools at their disposal.

Cedric Price, as mentioned above, explored a different avenue of the self-organizing system. The generative agents of his buildings were the inhibitors themselves. His Fun Palace was a freely interpretable construct - both physically and conceptually. While things could be added or subtract from the whole, the navigation through Fun Palace was not orchestrated either, and the building offered a great number of entering points and circulation sequences.

74 Keller, Sean. "Systems Aesthetics, or How Cambridge Solved Architecture", Architecture and Authorship, ed. by Anstey, Tim, Grillner, Katja, and Rolf Hughes (London: Black Dog Publishing Limited and the authors, 2007), 159. 
More recently, technology has been used as an allegorical tool rather than a means of direct influence on the project, explains Penelope Haralambidou, in The Allegorical Project. She mentions such practises as MVRDV, UN Studio, Ben Nicholson, Office of Metropolitan Architecture, and Michael Webb, who chose to distance themselves from the discourse over the immediate medium of a building or its construction site, to focus on rather the intermediate mediums, which are more familiar tools to use for an architects, such as drawings, texts, photography, paintings, models .etc. ${ }^{75}$ These practises use the generative methods (technological or not) as inspirations or more direct agents in their design process. In most cases these practises remain within the scope of architect's final decision. The generative medium in these cases acts as a binding agent between the theory and intent of the architect and the design process (often because of the immediacy and quickness which computer technologies offer).

For instance in his early work, between 1972 and 1977, Rem Koolhaas developed a set of architectural solution for New York. He rigorously produced a series of paintings that portrayed his historical analysis of the city in a narrative form. ${ }^{76}$ In Temple Island project, Michal Webb's generative medium was his "fleeting childhood recollection" that informed a set of extremely poetic drawings. ${ }^{77}$ Ben Nicholson in 1990 used a collage build of Sears and Sweets Catalogues as his architectural drawings. Finally, even computer generated form may be used as an allegory if it is used as a fruitful layer in a design process. For instance, Peter Testa and Devyn Weiser, of the Emergent Design Group at MIT, have developed an set of open source software Agency GP, Genr8, and Weaver. ${ }^{78}$ These use the computational capabilities of a

75 Haralambidou, Penelope. "The Alegorical Project: Architecture as'Figurative Theory", Architecture and Authorship, ed. by Anstey, Tim, Grillner, Katja, and Rolf Hughes (London: Black Dog Publishing Limited and the authors, 2007), 118 .

76 Haralambidou, Penelope. "The Alegorical Project: Architecture as'Figurative Theory', Architecture and Authorship, ed. by Anstey, Tim, Grillner, Katja, and Rolf Hughes (London: Black Dog Publishing Limited and the authors, 2007), 120.

77 Haralambidou, Penelope. "The Alegorical Project: Architecture as'Figurative Theory', Architecture and Authorship, ed. by Anstey, Tim, Grillner, Katja, and Rolf Hughes (London: Black Dog Publishing Limited and the authors, 2007), 120.

78 Tierney, Therese. "Biological Networks: On Neurons, Cellular Automata, and Relational Architectures”, in Network Practices, ed. by Anthony Burke, Therese, Tierney, (New York: Princeton Architectural Press, 
computer cluster to assimilate “...natural growth systems [in which]...a surface modelling program that involves artificial intelligence and complex feedback loops"79 generates an architectural form.

\section{社}

The authors of Futureground paper list a break down of possible subcategories of generative design which include “...self-organization, swarmsystems and ant colonies, evolution, and generative grammars ${ }^{\prime 80}$. If so, we can attribute most of these to the examples shown above: Prices work as a swarmsystem in which inhabitants are the formative agents; Alexander's and Rossi's architecture as a result of generative grammar; and the methods of Testa and Weiser who the subjects of controlled evolution within a cybernetic environment.

As we have already learned in architecture the authorship paradigm has fluctuated greatly in order to accommodate the many engaged agents, such as the different trades, shared ideologies, interconnected ideas, context, and even the needs and actions of the inhabitants. What is bluntly important about the phenomenon of self-organization, as we learn in this section, is the fact that it encourages shared authorships between the director(an architect in our case) and the respective design processes (including the agents involved in them).

\section{2.d> Professional survivalism}

While discussing the paradigm of architectural authorship, one is ought to question: Could it be that the discourse exists simply to sustain architecture as a viable profession? We know that architecture could be built as a systematic response to context, calculated by engineers, constructed by skilled trades, adjusted by its inhabitants, and given meaning by culture. Is it possible that architects have long exhausted themselves, and are now in search of a purpose?

2007),94.

79 Tierney, Therese. "Biological Networks: On Neurons, Cellular Automata, and Relational Architectures", in Network Practices, ed. by Anthony Burke, Therese, Tierney, (New York: Princeton Architectural Press, 2007), 96.

8o McCormack, Jon, Alan Dorin, Troy Innocent. 'Generative Design: a paradigm for design research' in Redmond, J. et. al. (eds) Proceedings of Futureground, vol.2, is.1, (Caulfield East Vic: Monash University, Faculty of Art \& Design, 2004), 1. 


\section{2.d.1> Legitimacy of architectural profession}

Discussion on the relationship between legitimacy and architecture has been an integral part of the architectural debate since the Renaissance. Postmodernism, however, introduced a completely new dimension into this discussion by questioning the very credibility and need for legitimacy. In fact Manfredo Tafuri and Kenneth Frampton, both exemplary critics of this issue, had asserted that legitimacy of architecture is already lost, and mainly due to modernization, constant technocratic progress and increasing consumption. Frampton in Reflections on the Autonomy of Architecture expands - "Ir is obviously difficult to sustain the legitimacy of architecture in a society that is constantly being overwhelmed by innovations of technoscience, by demographic change, and by the ever-escalating cycles of production and consumption that constant modernization serve to sustain." ${ }^{81}$ Tafuri adds that architecture's legitimacy weakened because architecture distanced itself from dealing with important social issues, and now must return to this fundamental function to regain its legitimacy back.

The core foundation of architectural legitimacy was formed in the mid XIX century. During that period, architects began to assemble into a professional category. They identified two sets of abilities, which were to distinguish them as a professional group: knowledge of "spatial organization and engineering" ${ }^{82}$, and "artistic and creative skills"

Due to the mounting pressure from engineers and progress within the building industry, architects had to provide a new reason for the existence of their assembly. At this point architects were becoming an optional service. The professional class of architects then responded by marketing themselves as "...indispensable in providing - for the great proletarian masses - housing with optimal hygienic conditions, in compliance with sociopolitical ideas of

81 Frampton, Kenneth. "Reflections on the Autonomy of Architecture: A Critique of Contemporary Production", in Out of Site: A Social Criticism of Architecture, ed. by Diane Ghirardo (Seattle: Bay Press, 1991)

82 Van Dijk, Hans. "Architecture and Legitimacy. Styles and Strategies", in Architecture and Legitimacy, ed. by Hans van Dijk, Liesbeth Janson, transl. by D'Lane Camp, Donna de Vies-Hermansader, (Rotterdam: NAi, 1995), 12.

83 Van Dijk, Hans. "Architecture and Legitimacy. Styles and Strategies", in Architecture and Legitimacy, ed. by Hans van Dijk, Liesbeth Janson, transl. by D'Lane Camp, Donna de Vies-Hermansader, (Rotterdam: NAi, 1995), 12. 
egalitarianism"84. In other words, they attempted to turn architecture from a bohemian profession into a necessary one. From that point on this shift has turned into a cyclical phenomenon, in which architects are forced to constantly choose between conducting a practice of necessity, in which engineering becomes a great competitor, or an act of art that is exclusive to whoever can relate and afford.

\section{2.d.2> Naming and Branding. Legitimizing? (optional)}

Branding could be also interpretable as a legitimizing action.

It could be that through branding architects get to define their purpose. By promoting their authorship they explicitly label each creation as a product of architecture, and with this gesture preserve their profession. Thus, architectural practices titled with personal names resurrect the impression of a single creator. It is not a surprise than, that despite the fact that in theory architectural authorship is no longer egocentric, the attribution of one author to a work is ever so strong. It is as if for the ease of semantic reference that we need to have an architect as a signifier. Even the infamous Team 4, whose name was specifically devised by Richard Roger as a detest to the "cult of the individual" ${ }^{\text {, }}$, quickly unravelled into multiple architectural practises respectively named after the personal names of its founding members: Foster Associates, Richard + Su Rogers, Piano + Rogers, Richard Rogers Partnership, Sir Norman Forster and Partners, etc..

However, the naming of architectural firms may not necessarily be a sign of a single authorship. After all, it is often a matter of branding, while not all architectural practises are hierarchical, autocratic, or at all constrained by the physical proximity of their agents. For instance servo, Ocean North, Emergence and Design Group, Small Design Firm, and some others described in the Network Prctices: New Strategies in Architecture and Design made a point of utilizing the

84 Van Dijk, Hans. "Architecture and Legitimacy. Styles and Strategies", in Architecture and Legitimacy, ed. by Hans van Dijk, Liesbeth Janson, transl. by D'Lane Camp, Donna de Vies-Hermansader, (Rotterdam: NAi, 1995), 13.

85 Powell, Kenneth. Richard Rogers. Complete Works, vol.1, (London: Phaidon, 1999), 13. 
"network feedback as a platform for innovating the nature of practice, the nature of the objects of that practice, the site for their designs, and as a business model" ${ }^{186}$. Ex members of Team 4, OMA, emphasize the multi-authored nature of their work.

\section{2.d.3> Is architectural profession necessary?}

Even though architecture is not legitimate, according to M. Tafuri and K. Frampton, it has a right to exist, while its necessity is yet another issue.

In language of Linux programming the term meta package is known to signify a file or an entity that holds the connections to many smaller functions, which comprise a larger program. We could then establish that architectural profession is yet another meta package only of the built environment. Architectural practises today often act as a binding glue of many trades that build, design, critique, and commission. It is the agency that does not require legitimacy to exist, and thusly can not be exhausted, as long as it is identified as a superconductor.

As Hans van Dijk explains, in Architecture and Legitimacy, architecture is loosing it credibility and legitimacy in the eye of the society. It accepts “...its diminishing role within a technocratic world, where, $[. .$.$] performance is the only thing that counts" { }^{87}$. This means that regardless of quality, efficiency will be always rewarded. While architecture acts as a meta package it ensures the presence of all the necessary trades in the business of building. When architecture is gone, who will have the tools, or the will, or the knowledge to ensure quality?

\section{2.d.4> Could open source preserve architectural profession?}

Michael Speaks in his essay, Two Stories for the Avant-Garde ${ }^{88}$ of 2000, gives a critical review of the Modern architecture. According to him, while having arrived in the North America "...its

86 Hight, Christopher. "Scalar Networks, Super Creeps: Approaching the Non-Standard in the Architecture of Servo", in Network Practices, ed. by Anthony Burke, Therese, Tierney, (New York: Princeton Architectural Press, 2007), 104.

87 Van Dijk, Hans. "The Prepositions", in Architecture and Legitimacy, ed. by Hans van Dijk, Liesbeth Janson, transl. by D'Lane Camp, Donna de Vies-Hermansader, (Rotterdam: NAi, 1995), 17.

88 Speaks, Michael, "Two Stories for the Avant-garde II", in Architab. Radical Experiments in Global Architecture, ed. by Migayrou and Brayer, (London: Themes\&Hudson, 2001), 201. Also http://www.archilab.org/public/200o/catalog/speaksen.htm (accesed: April ut ${ }^{\text {th }}$, 2009) 
ideology was either left behind in Europe or was dropped off somewhere deep in the ocean. Only the formal elements arrived in America, to become 'The International Style"'89. $\mathrm{He}$ depicts two different stories of architectural avant-garde in North America. The avant-garde of the 1980s and the avant-garde of the 1990s. The first was driven and dominated by theory. The main objective of this movement was to reestablish connection between form and ideology. For architecture it meant reinstatement of its social mission. Yet, this type of avantgardism was averse to the newly emerging commercial reality driven by globalization.

Second avant-garde, in sight of globalization was comfortable with the idea that architecture should not isolate itself from the business realm, and became a part of it. The economic forces began affecting production in the architectural field just as they did in any other commercial field. This new avant-garde was motivated by commercialism and demand for innovation. It lacked any definitive historical or cultural mission. In fact, managerial approach to architecture was necessary not only to enable it to deal with the challenges posed by globalization, but also to seize the opportunities that were created by the effects of globalization.

Today, in the world where developer firms can offer great efficiency, speed, quantity, and lower expenses, architectural services are at a risk of extinction. Many designs get built, rebuilt, mirrored, multiplied, stacked, and stripped of expressive, custom, and expensive features. Only custom design, requires an architect, and only by holding the authorship for that design an architect can ensure that the design remains unique. In this format, proprietorship sustains the architectural practises, but only as a an expensive and eclectic alternative, which often requires either trust or an architectural expertise to be appreciated. However, in todays society, according to van Dijk, rarely who sees the architectural profession as an obvious domain, or utterly trusts and believes that architects know the "right" way of building. Thusly, developer firms benefit from architectural proprietorship even more. While competing in the same market as the architectural practises, they offer many analogous services, such as design,

89 One Architecture. "Corporate Avante-Garde", in Hunch 6/7, ed. by Sigler, Jennifer, Roemer Van Toorn, W M J Arets, (Rotterdam: Episode Publishers, 2003), 368. 
execution, and construction, but with the exception of case specificity(geographic, personal, situational etc.) - a facet whose demand is directly proportional to the architectural education of the society. Yet, how is architecture to explicate the knowledge of its purpose if it remains a closed proprietary system? Its ways are secretive as are those of developers', leaving only the product of their work to be the measure of quality. But then again, quality without knowledge and context is prone to an unfair appraisal.

In an attempt to meet and survive the challenges posed by the globalization, Speaks makes a bold assertion that "...architecture should no longer recoil from the degraded world of business and corporate thinking; on the contrary, it should aggressively seek to transform itself into a research-based business" 90 . This means that above all theoretical discourse must be regained and it needs to become a public phenomenon. Architecture can no longer be a proprietary business and needs to begin producing knowledge into the public domain. Van Dijk elaborates that legitimacy of architecture can be retrained only

"...when both the debate and the practice of architecture attempt to reconnect architecture as a cultural activity, to an adequate understanding of the capabilities of the profession within economic cycles, social structures, political decision-making processes, and the world of the media." ${ }^{91}$

Moreover he explains that in sight of globalization architecture can no longer count on being legitimized through history, ${ }^{92}$ and instead it ought to

"...overcome, disturb, or even sublimate the forces of the modernization process to which it is exposed. It must subsequently redefine its own position as a critical activity within the surrounding world."93

All these criticisms are addressed well by the features offered in the open source approach. It encourages the liberation of knowledge and has proven to sustain an active community that

90 Speaks, Michael, "Two Stories for the Avant-garde II", in Architab. Radical Experiments in Global Architecture, ed. by Migayrou and Brayer, (London: Themes\&Hudson, 2001), 201. Also http://www.archilab.org/public/200o/catalog/speaksen.htm (accesed: April $11^{\text {th }}$, 2009)

91 Van Dijk, Hans. "The Prepositions", in Architecture and Legitimacy, ed. by Hans van Dijk, Liesbeth Janson, transl. by D'Lane Camp, Donna de Vies-Hermansader, (Rotterdam: NAi, 1995), 18-19.

92 Van Dijk, Hans. "The Prepositions", in Architecture and Legitimacy, ed. by Hans van Dijk, Liesbeth Janson, transl. by D'Lane Camp, Donna de Vies-Hermansader, (Rotterdam: NAi, 1995), $20-25$.

93 Van Dijk, Hans. "The Prepositions", in Architecture and Legitimacy, ed. by Hans van Dijk, Liesbeth Janson, transl. by D'Lane Camp, Donna de Vies-Hermansader, (Rotterdam: NAi, 1995), 28. 
engages deeply in the topics of discourse. Kevin Kelly, founding executive editor of the Wired magazine and an expert of the digital culture, in his book New rules for the new economy ${ }^{94}$ argued that "...in the near future three features will distinguish the new economy: it will be global, it will favor intangible, soft things over tangible hard things, and it will be networked" In the field of software development, open source practices have numerously proven their competence to survive the challenges imposed by the economy of globalization. Such success could not be taken for granted and as long as it transposes equally well into the architectural realm, its ubiquity and accessibility will ensure "...to reconnect architecture as a cultural activity". Moreover, once the architectural source becomes freely available, architectural actions would be exposed and hopefully appreciated for their competency. Ultimately, this revelation will strip the mass architecture off its superficial acclaim to show the economic nature of its motives and values.

This prognosis in not a complete speculation, as some architectural practices have already begun engaging in some aspects of open source activity with apparent success. KRETS/AKAD, servo, Ocean North, Emergence and Design Group, Small Design Firm and many more are network practices that make use of the Internet technologies to decentralize and coauthor their work. They use the networks both as conduits of information and the very bases for some projects. Network Practices' work is experimental and often becomes an artifact of architectural theory exhibitions. Christopher Hight, also adds that network practices "...convert architectural questions into the 'subject matter of architectural knowledge production' by transforming the objects of practice into the ground for a reconstruction of practice itself..." ${ }^{\prime 9}$. This capacity to evolve the architectural profession, as wells as its cultural impacts can not be taken for granted.

94 Kelly, Kevin, New Rules for the New Economy : ıo Radical Strategies for a Connected World, (New York, Penguin, 1999), 1-179.

95 Speaks, Michael, "Two Stories for the Avant-garde II", in Architab. Radical Experiments in Global Architecture, ed. by Migayrou and Brayer, (London: Themes\&Hudson, 2001), 201. Also http://www.archilab.org/public/200o/catalog/speaksen.htm (accesed: April 1 ${ }^{\text {th }}$, 2009)

96 Lipstadt, Helene. "Exoticising the Domestic': on New Collaborative Paradigms and Advanced Design Practices' in Architecture and Authorship, ed. by Anstey, Tim, Grillner, Katja, and Rolf Hughes (London: Black Dog Publishing Limited and the authors, 2007), 169. 
There is even more to what the open source can rectify. Kelly speculates that due to digital media the western value system is in the process of a drastic change. In his essay Better Than Free $\mathrm{He}$ explains that because of the nature of the Internet technologies, and the constant copying of content from one server to another, information can not be controlled for long and will inevitably become free - both free as in "free speech" and free as in "free beer" (to rephrase the founder of the free- software movement - "not 'free' as in 'free beer', but 'free' as in 'free speech' $\left.^{\prime 97}\right)$. As a result this free flow of information would undermine the already established order of an economy based on selling information(ie. architectural solutions and drawings). This speculation in not exclusive to the world of digital media but, according to Kelly, will effect all industries. He asks a rhetorical question: "If reproductions of our best efforts are free, how can we keep going?[...]how does one make money selling free copies?"98 and responds that "stuff which can't be copied becomes scarce and valuable". He continues to describe eight "generatives" that will allow free practices to also be lucrative - immediacy, personalization, interpretation, authenticity, accessibility, embodiment(ie. digital to tangible), patronage(ie. desire to reward), and findability.

In other words, Kelly's speculation renders open source business model a rather natural step in the economic and professional evolution. In this evolution the architectural profession would be legitimized because the "generatives" that he describes are the case specificities that the profession offers.

Lastly, yet most importantly, making the source of architectural practices open to everyone will make this knowledge available for entrepreneurs. This will boost the pace and depth of architectural education. Young architects and firms will use the same tools available to mature professional - closing the gap posed by professional experience, and giving way for creativity. The latter is affirmed by Dennis Kaspori, as he explains how young architectural practices are

97 Stallman, M. Richard, Free Software, Free Societies, ed. by Joshua Gay, (Boston: GNU Press, 2002), 57. 98 Kelly, Kevin. "Better Than Free", in The Technium, http://www.kk.org/thetechnium/archives/2008/o1/better_than_fre.php (accessed April 13 $3^{\text {th }}$, 2009) 
often too preoccupied with "rediscover[ing] the wheel with every new project" $"$. He suggests that “...inventiveness would be better off redirected to the organization of practice using a 'collective approach'"'100.

\section{3) Forgetting craftsmanship}

At present, the word Craftsmanship is rarely of use and has little to signify in the daily lexicon. While, dictionaries generally use themes of handiwork, exceptional manual dexterity, and traditional family trades in an attempt to simulate a definition ${ }^{101102}$, in the western world none of those references have been applicable since the industrial revolution. Indeed, it may seem that the concept of craftsmanship is simply obsolete today.

However, concerned with the human values in the context of today's economy, New York University and London School of Economics sociology professor Richard Sennett, in his book The Craftsman, makes an in-depth historical enquiry regarding the meaning of the word craftsmanship. By finding some of its lost connotations he unveils how their progressive dissolution explains the ethical and socioeconomic changes that took place in the western world from antiquity until today. These are closely related to the dynamics of the authorship paradigm.

To begin, Sennett directs the reader to the Homeric Hymn about the god Hephaestus, who similarly to the aforementioned Prometheus taught humans the art of many crafts:

"...men who before used to dwell caves in the mountains like wild beasts. But now that they have learned crafts through Hephaistos the famed worker, easily they live a peaceful life in their own houses the whole year round"103.

99 Lipstadt, Helene. "Exoticising the Domestic': on New Collaborative Paradigms and Advanced Design Practices' in Architecture and Authorship, ed. by Anstey, Tim, Grillner, Katja, and Rolf Hughes (London: Black Dog Publishing Limitedand the authors, 2007), 167.

100 Lipstadt, Helene. "Exoticising the Domestic': on New Collaborative Paradigms and Advanced Design Practices' in Architecture and Authorship, ed. by Anstey, Tim, Grillner, Katja, and Rolf Hughes (London: Black Dog Publishing Limitedand the authors, 2007), 167.

101 The American Heritage Dictionary of the English Language, 4th edition (Boston: Houghton Mifflin Company, 2007).

102 WordNet 3.o dictionary (Princeton University, 2006), http://wordnet.princeton.edu (accessed March 27th, 2009)

103 The Homeric Hymns and Homerica. In "Homeric Hymn 20 to Hephaestus", Trans. by Hugh G. Evelyn- 
This reference is important in the way that it celebrates craftsmanship for being directly responsible for peoples comfort and happiness within a community. It is no wonder then, that craftsmanship translates from Greek as demioergos - a compound word that links both the public(demios) and production(ergon) as interdependent entities ${ }^{104}$. In addition, Sennett notes that different trades throughout antiquity were honoured equally because it was believed that their symbiosis, rather than a hierarchy, made a community possible. The passing of knowledge and skills through the generations was a sustainable way to maintain a diverse skill pool. It was a duty greater in importance than the intrafamilial relations. In such a scenario, according to Sennett, the "...personal 'genius' - had little meaning in the context" ${ }^{105}$.

However, starting with the classical era an hierarchical system began taking dominant form in which only the uppermost and most vital trades retained honour, while others were demoted as generic services. For instance, because pottery satisfied an elementary need it was assumed "stupid"106 rather than essential, and thus, by association, such process of making was not viewed as art any longer, but rather an undisclosed chore. In sight of that tendency, Aristotle, introduced the word cheirotechnon (hand worker) instead of the old demioergos to make a clear separation between the craftsman and the "architect", where the former is a miscellaneous labourer, and the later is one that "...possess[es] the theory and know[s] the causes"107.

Today, the meaning behind cheirotechnon is still sound. It captures many aspect of the western society, where one's subordinacy is simply unavoidable within the complexity of modern life. In the corporate world very few who could claim to be an all-in-one architect, designer, and producer, while staying competitive. As a result, issues of shared authorship, personal satisfaction and professional honour are often severely overlooked.

White, (Cambridge, MA.: Harvard University Press; London, 1914),. 104 Sennet, Richard. The Craftsman, (New Haven \& London: Yale University Press, 2008), 22. 105 Sennet, Richard. The Craftsman, (New Haven \& London: Yale University Press, 2008), 22. 106 Sennet, Richard. The Craftsman, (New Haven \& London: Yale University Press, 2008), 23. 107 Aristotle. Metaphysics, in "Aristotle in 23 Volumes", Vols.17, 18, trans. by Hugh Tredennick, (Cambridge, MA: Harvard University Press, 1934). 
In response, Sennett makes a bold speculation that the above mentioned open source model of work management is one that most successfully captures the ancient principles of craftsmanship. In it each individual skill is appreciated and viewed as a building block of society. 


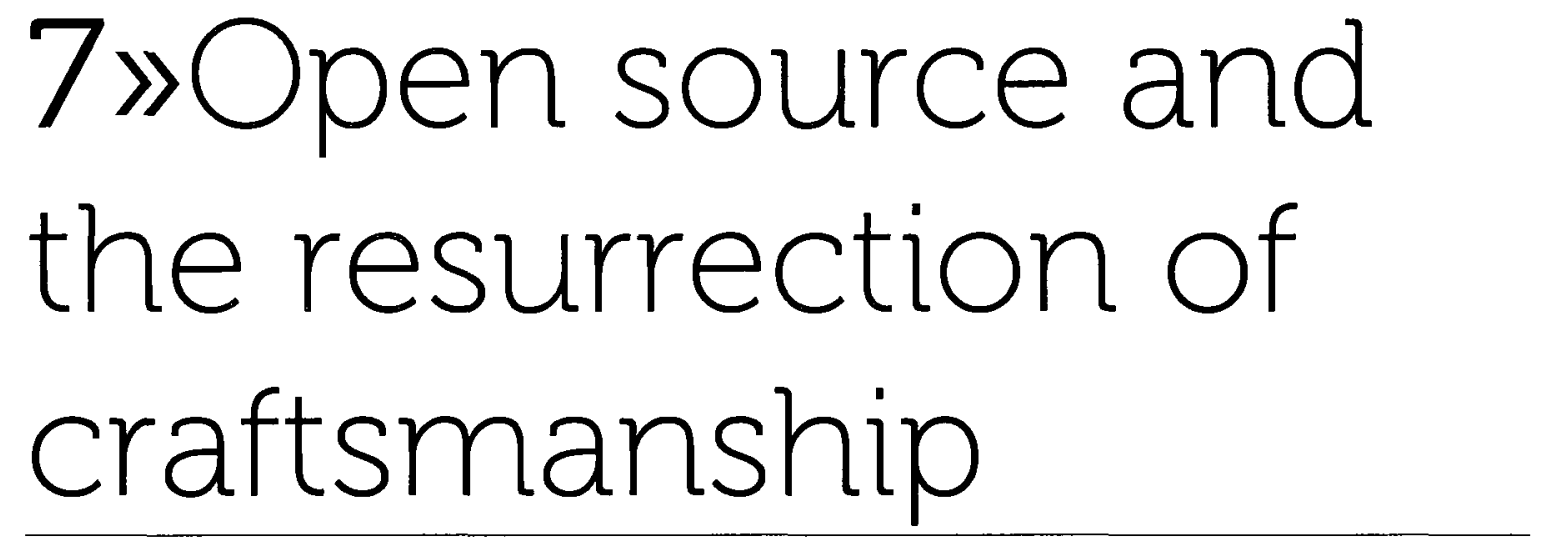

In order to understand the benefits of the open source approach, we shall evaluate it through a comparison with the current state of authorship paradigm and its criticisms, some of which were presented in the preceding sections.

\section{1) Professional community.}

To begin with, we saw that existence of a community is important to the crafts, but even more so craftsmanship is dependant on the community. The discourse within it, criticism, and adaptation to challenges are what keeps the tools and methods evolving. Sennett, confirms this fact using the historical evolution of pottery making. ${ }^{108}$

Unfortunately, in a proprietor prevalent society a craftsman community is established through a professional association, which also happens to legitimize and govern its patrons. In this format the lines are blurred between the concepts of authorship and ownership. As a result, not only, extracurricular influences are highly improbable, because personal interest and activism are of no value in such status bound community; but also incubation of ideas, collaboration, and general evolution of a profession is not very straight forward. It is rather ironic for one institution to both copyright intellectual properties and accommodate their

108 Sennet, Richard. The Craftsman, (New Haven \& London: Yale University Press, 2008), 26. 
sharing and concoction, especially since the copyright law is a one-size-fits-all approach, while modes of collaboration tend to vary per case.

On the other hand, the open source community lacks a copyrighting mechanism. Quite the contrary; a variant of a GNU General Public License(GPL), otherwise known as Copyleft, is in place to prevent patenting of content, while promoting sharing, modification, forking and collaboration. In addition, the community does not need a centralized body to sustain itself. Instead, communication and sharing technologies are the very vehicle of the open source community. One's status is an obsolete notion here, which can only be distantly likened to honour (as it was discussed with regards to ancient craftsmanship) or the volume of ones contributions. Thusly, professional communication in the open source communities is a thriving melting pot in which "...the process of skill evolution is speeded up; change occurs daily." ${ }^{109}$. In the case of the Linux operating system software, evolution can be noticed on daily basis though constantly emerging updates. The reason is that, although the developing community is large, there are only a few quality assessing agencies through which a code passes before being released. This may increase the risk of the developers missing a bug, but in return a much greater responsiveness to such mishaps is possible. In addition, the rapid evolution excites and engages the community because each member in it feels the immediacy of the power to influence the source.

\section{2) Quality and evolution}

Another important issue in authorship is the quality of products and processes, because rarely does one wants to be credited for a failure.

Craftsmanship, as it is described by Sennett, was inherently of an impersonal character. ${ }^{110} \mathrm{As}$ skills were passed through generations there was little for one to claim as authored. Here, honour realized what later reincarnated as the 'pleasure of authoring'. The quality of one's

109 Sennet, Richard. The Craftsman, (New Haven \& London: Yale University Press, 2008), 26. 10 Sennet, Richard. The Craftsman, (New Haven \& London: Yale University Press, 2008), 27. 
products was the ultimate means of promotion, and vice versa, one's success was a gauge of quality. Sennett elaborates even further:

"All craftsmanship is quality-driven work; Plato formulated this aim as the arete, the standard of excellence, implicit in any act: The aspiration for quality will drive a craftsman to improve,to get better rather than get by."

In contrast, the modern author is often confronted with the dilemma of choosing between either surrendering their rights and intellectual properties in exchange for the benefits of being associated with a prominent brand; or authoring their own work (while the validity of such action can not be taken for granted) and accepting the burden of self promotion, necessary for economic feasibility. As a result, although, success is still often assumed to be the gauge of quality, the incentive behind ones work could be threefold - either success, or quality, or a concoction of both.

Since, open source developers are generally enthusiasts the issue of career success to them stands secondary to quality. At the forefront are personal affection to the subject matter, dedication, and desire to improve it. As the sociologist C. Write Mills explains with regards to craftsmanship: "The laborer with a sense of craft becomes engaged in the work in and for itself: the satisfactions of working are their own reward "112. This observation translates well to describe the open source labourer. Their products remain constantly under development, where no deadlines or other bureaucratic criteria exist to implement any form of finalization. Demioergos and the open source activist both conduct change simply as it comes along. This often results in small and unequal increments that inform a rather gradual progression, which could be taken advantage of by other dependant trades. On the other hand, the cheirotechnon is reserved to publicize their alterations in large proportional releases - something that each time could be marketed as a novelty that is superior to the former product. In this format, the dependant trades are constantly conditioned into using outdated tools.

111 Sennet, Richard. The Craftsman, (New Haven \& London: Yale University Press, 2008), 24. 112 Sennet, Richard. The Craftsman, (New Haven \& London: Yale University Press, 2008), 27. 
A proprietary product relies on keeping its methods patented and copyrighted to remain competitiveness. As long as it offers features that are otherwise unattainable, it can afford to exhaust the marketing potential of each product before offering the next improvement. Here the quality is hardly the driving force. On the contrary, lack of it creates future demand.

On the other hand, the shear fact that the open source developers leave their processes exposed shows their interest in creative criticisms, and disinterest in the game of authoring. Quality is their foremost goal. However, this does not yield open source uncompetitive. It, rather, undoes the secrecy behind the closed and competitive practises, which, in turn, agitates a grater competition for quality in the proprietary world. This could be the pattern to which Sennett refers when he says that "In the history of handcrafts, closed knowledge-systems have tended toward short lifespans"113. In software development we saw many examples of this pattern. For instance, the Firefox Internet browser which, from the technological point of view, rendered the industry's giant Internet Explorer nearly obsolete - only to trigger a plethora of improvement to come. "To say they[Firefox] have been well received is an understatement...” ${ }^{114}$. After the introduction in the 2004, “...Firefox gained world wide market share at a rate of nearly $1 \%$ per month from November to April" and keeps growing.

\subsection{Hierarchy and heterarchy.}

\section{3.a> The problem with hierarchy}

Today, the field of action within many trades, and especially architecture, remains a hierarchical system. It begins with a stratified structure within the architectural firms and ends with a monstrous, yet again, pyramidal bureaucratic cluster of building quality councils.

There is a problem with the hierarchy, however. By definition, it relies on the division of a single task into multiple micro-processes. The number of micro-processes grows in a

113 Sennet, Richard. The Craftsman, (New Haven \& London: Yale University Press, 2008), 26. 114 DiBona, Chris, Mark Stone, Danese Cooper, Open Sources 2.0: The Continuing Evolution, (Sebastopol: O'Reilly, 2006), 18. 
logarithmic progression in relation to the growth of the main task, and thus results in a fast and progressive distancing of the worker from the decision making apparatus. In simple terms, a craftsman found at the bottom of such an hierarchy, while fully preoccupied, is expected to be only skilled enough to remain productive, while preforming a scope of work that is narrow enough to sustain them as a dispensable trade. At the workers' level this pattern discourages attempts of innovation and retards the evolution of a profession as a whole. Consequently, the profession(or a practise at a lower level) risks to become a closed system - a mere function - an entity as static as all of its active parts.

In economics and political science this phenomenon is known as the principal-agent problem. ${ }^{115}$ It states that agents(workers) are often discouraged from innovation, if they have no way of reaching the top executive level where they could influence the decision making. Conversely, the principals(directing a group of people) have a hard time monitoring the agents' actions, which impedes accountability and diminishes productivity. Additionally, the principals who are more competent (and “...possess the theory and know the causes"116) do not have the sufficient resources to initiate innovation in their own right. They are simply preoccupied with their organizational chores and can only obtain a limited amount of feedback from the many agents. This communication is simplex - flows from top to bottom only(Illustration 4).

Sometimes the principles are able to obtain the necessary feedback information from their agents, however, this involves higher "transaction" and "opportunity" costs. This is generally done through implementation of multiple rules and regulation, which include monitoring of quality, progress, attendance, etc.; as well as enforcing a feedback mechanism as part of the agents duty. All these come at the expense of the agents' time and effort.

115 De la Mothe, John, Albert N. Link. Networks, alliances, and partnerships in the innovation process, (Norwell: Springer, 2002), 34 . 16 Aristotle. Metaphysics, in "Aristotle in 23 Volumes", Vols.17, 18, trans. by Hugh Tredennick, (Cambridge, MA: Harvard University Press, 1934). 
There is another way to manage progress explain Jürgen Bitzer and Philipp J. H. Schröder in the The Economics of Open Source Software Development. According to them the open source:

"...challenges orthodox principal-agent notion of agency, i.e. of the efficient management of agents, by exploiting the inherently dispersed and decentralized capabilities of self-selected agents. Put another way, rather than putting a principal in charge, in order to ensure an efficient, albeit far from costless, discovery of useful knowledge, an F/OS-based design entails letting productive knowledge search for its own organization." ${ }^{117}$

In short, what Bitzer and Schröder demonstrate are the differences between the hierarchical and heterarchical(Illustration 5) systems. Here, a hierarchy is the structure of a typical proprietary business, and the beterarchy is the mode in which an open source practise operates. As we already saw, In the hierarchical structure each elements has only the ability to influence its dependencies. However in the heterarchical system each element shares an equal opportunity to influence all other elements. Also in "...a heterarchy, decisions are reached by dialogue rather than dictate"118.
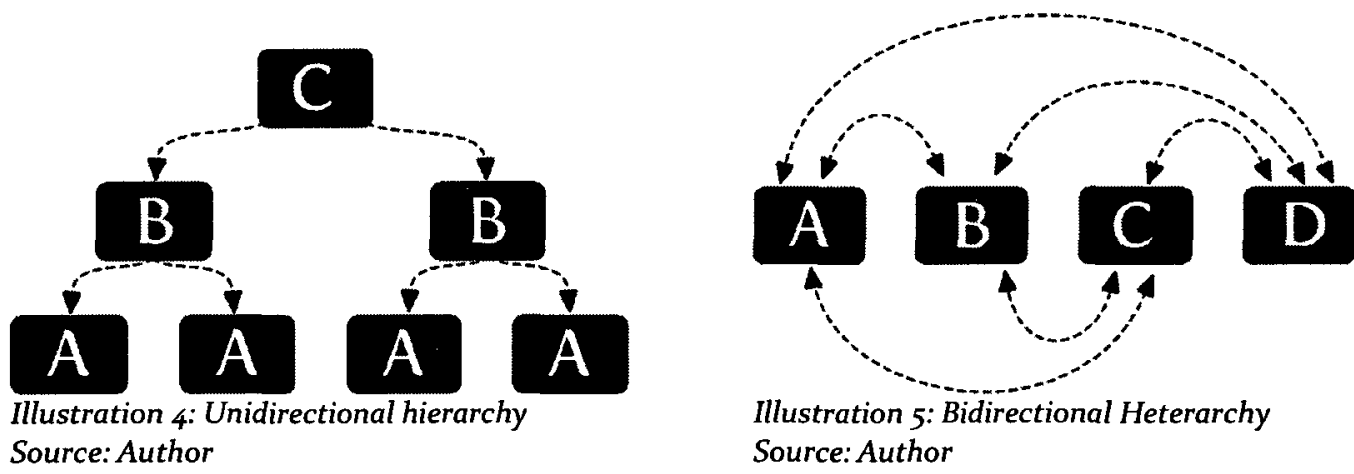

Illustration 5: Bidirectional Heterarchy Source: Author

Structurally speaking, understanding the difference between the open source and the proprietary approaches is rooted in the relationship between the heterarchical and the hierarchal. So, how does heterarchy deal with the mentioned limitations of hierarchy?

117 Bitzer, Jürgen, Philipp J. H. Schröder. The Economics of Open Source Software Development: Analyzing Motivation, Organization, Innovation and Competitions in the Open Source Software Revolution, (Bingley: Emerald Group Publishing, 2006), 200.

118 Fuller, W. Robert. All rise: somebodies, nobodies, and the politics of dignity, (San Francisco: Berrett-Koehler Publishers, 2006), 182. 


\section{3.bs Introducing heterarchy}

In a modern context the concept of heterarchy was first used in 1945 by a medical doctor, and an early cybernetician, Warren McCulloch. ${ }^{119}$ At the time, he was studying the brain and the human mind in search for an alternative way to represent the organization of cognitive structures, which he then coined as heterarchy. His discovery was that the brain is "while reasonably orderly was not organized hierarchically" ${ }^{120}$. The human mind assumes that all ends or goals could be arranged linearly from the least to the most important - $A$ to $B$ to $C$ etc..

However, this illusion is quickly dissolved, when one realizes that primal goals do not always come after the subordinate ones, and $C$ could sometimes come before $A$ (Illustration 6). ${ }^{121}$ As a result, this “...understanding revolutionized the neural study of the brain and solved major problems in the fields of artificial intelligence and computer design"122.

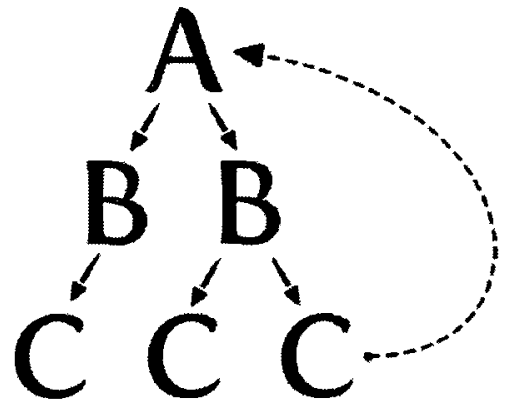

Illustration 6: Simplified heterarchy Source: Author

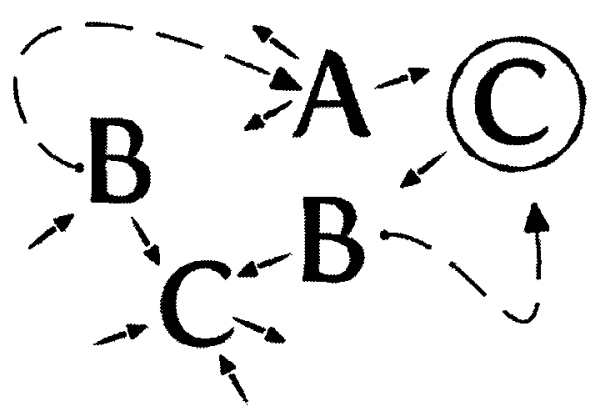

Illustration 7: Simplified anarchy diagram Source: author

Heterarchy should not be confused with anarchy, in which relationships are simply unpredictable (Illustration 7). In addition, it is possible for a hierarchy to contain heterarchical parts and vice versa. Thusly, either of the systems should not be understood as exclusive, but rather as complementary tools. Hierarchy offers a simplified, easy to understand diagrammatic way to depict a certain structure, where as, heterarchy depicts a more precise reality with all the

119 Gill, B., Richardson. The Great Maya Droughts: Water, Life, and Death, (New Mexico: UNM Press, 2001 ), 58. 120 Dmitri Bondarenko. "A Homoarchic Alternative to the Homoarchic State: Benin Kingdom of the 13th - 19th Centuries". In Social Evolution \& History. Vol. 4, No 2.(2005), 18-88.

121 Gill, B., Richardson. The Great Maya Droughts: Water, Life, and Death, (New Mexico: UNM Press, 2001 ), 59. 122 Dmitri Bondarenko. "A Homoarchic Alternative to the Homoarchic State: Benin Kingdom of the 13th - 19th Centuries". In Social Evolution E History. Vol. 4, No 2.(2005), 18-88. 
minor nuances. For this reason, it is understandable why one often gravitates towards an orderly hierarchical organization, because a heterarchical model often seems convoluted and deceptively inefficient.

However, in reality heterarchical systems are capable of processing more information and more effectively than a hierarchical design. Different parts of a heterarchy may work independently on unrelated tasks, while working towards a common goal. They rarely run the risk of developing a bottleneck effect as communication nears the head of the power, the way that a hierarchal system does. All of its parts are interrelated and could act both as agents and principals, resulting in a symmetric system that boasts full duplex communication. Such system is self healing, as it will not be parallelized by the the failure of one principle.

For these reasons, and many more, heterarchy "...has gained considerable popularity in the world of cybernetics where it is defined as a form of organization resembling a network or a fishnet. The Internet, for example, if often described as a heterarchy. ${ }^{123}$ In fact, Internet was conceived with the benefits of a heterarchy in mind.

Heterarchy manifests itself in anything that acts as a swarm, including many natural phenomena(ant nest, memory, social relationships, etc.) and advanced technological networks(telephony, roads, flight routs, etc. ). Likewise, the open source acts as a heterarchy, and therefore adopts a structure that is ubiquitous and proven to work for millennia rather then a rigid, orderly, and easy to grasp structure.

\section{3.c Heterarchy in architecture}

In architecture the concept of a heterarchy is rather novel either. In some cases architectural firms, like Skidmore, Owings \& Merrill[SOM], in the 1970s had attempted to run practises that were internally heterarchical. ${ }^{124}$ However, today, Lebbeus Woods, is the most prominent figure in this discourse. Throughout his work he has numerously proposed urban design

123 Gill, B., Richardson. The Great Maya Droughts: Water, Life, and Death, (New Mexico: UNM Press, 2001 ), 59. 124 Porter, Tom. Archispeak: an illustrated guide to architectural terms, (London: Spoon Press, 2004), 95. 
schemes comprised of "heterarchical urban forms" 125 . He called these Freespace, and implemented them in his Berlin and Zagreb Free-Zone projects. Free-zone, being a larger network containing the many Freespace[s], is “...a system devoid of mass culture (which Woods sees as diminishing the autonomy of the individual)"126. According to Woodsian understanding, in such a place urban and architectural patterns are organized by knowledge, innovation and performance, as opposed to one's status. ${ }^{127}$ Woods also speculates that technologically aided communication would become an essential medium for interaction and dialogue.

To Woods heterarchy is a spontaneous framework, where authority is centred around individual invention, intervention, and enthusiasm. He believes that architecture should also follow suit and never be considered complete. It would always remain in a dynamic state of becoming, which only a heterarchical existence could facilitate.

These words summarize well his critical stance as an urbanist and social architect, who sees today's socioeconomic structures as obsolete, and calls for change:

"Contemporary society, which is characterized by indeterminacy, uncertainty, and ambiguity, is in a state of continual transformation. Autonomy of the individual is paramount, but existing models of urban organization are incapable of guaranteeing the individual's autonomy in this new fluid state. They cannot accommodate or facilitate the dynamic equilibrium of shifting networks of individuals and groups and thus are no longer relevant. Hierarchy - the system of stasis, predictable patterns, determinacy, and unidirectional communication - must give way to heterarchy, a dialogic urban order with many centers that are configured and reconfigured according to the needs of their inhabitants.

Heterarchy demands a completely new kind of space that allows one to live experimentally, unconstrained by a conventional architectural program or the uses and behaviours prescribed by its functions. This new tectonic is the freespace, and architectural unit of undetermined purpose that is given meaning only through its utilization by autonomous individuals. Freespaces can be electronically linked to form a network called a free zone, a new urban pattern, marked by mobility and the dynamic exchange of knowledge. Although the freedom entailed in living experimental requires that one relinquish given options and the comfort they afford,

125 Woods, Lebbeus. "The Question of Space", Technoscience and Cyberculture. Eds. Stanley Aronowitz, B.

Martinsons, and M. Menser, (New York: Routledge, 1996.), 279-292 . 126 Porter, Tom. Archispeak: an illustrated guide to architectural terms, (London: Spoon Press, 2004 ), 95. 127 Porter, Tom. Archispeak: an illustrated guide to architectural terms, (London: Spoon Press, 2004 ), 95. 
it is only through this mode of living that one can invent the life that allows him or her to determine most fully what it means to be human. It is the ethical responsibility of architecture not simply to invent new spaces for and conditions of living, but act as an instrument of change and even foment it." ${ }^{128}$

Recently Woods has also addressed this point of view in his design submission to the architectural completion for reconstruction of the World Trade Center in New York. He proposed a structure that would forever undergo construction. Named "World Center" the building would have grown infinitively to symbolize USA's ability to regenerate itself and constantly change.

\section{站}

Another thinker, who shares similar perspectives with Woods is Peter Lamborn Wilson, a political critic, an anarchist, and an urbanist in some sense, acting under the generic pseudonym of Hakim Bey. Bey began his work with a research on the piracy of the $18^{\text {th }}$ century - a subject that at the time had "appeared as if no historian has yet found them worthy of analysis"129. He was interested in the small secret pirate islands that at the time existed away from law and any government's reach. They were autonomous societies that functioned as provision depots and havens for those who believed in the ways of anarchy. Bey named those Pirate Utopias, and developed a revised modern vision that would be able to exist in the near future, which he named a Temporary Autonomous Zone (TAZ). He described the $T A Z$ as an:

“...uprising that does not engage directly with the State, a guerilla operation which liberates an area (of land, of time, of imagination) and then dissolves itself to re-form elsewhere/elsewhen, before the State can crush it..." ${ }^{130}$

Unlike the free-zone Bey's TAZ, as described in the book T.A.Z.: The Temporary Autonomous Zone, Ontological Anarchy, Poetic Terrorism, is set in a fictional setting. It is to be a phenomenon ready for a dystopian future, which according to Bey would be heavily

128 Woods, Lebbeus. Anarchitecture: Archietcture is a political act,in Architectural Monographs no.22, (London, Academy Editions, 1992), 64.

129 Bey, Hakim. "The Temporary Autonomous Zone”, in Crypto anarchy, cyberstates, and pirate utopias, ed. by Peter Ludlow, (Cambridge, MA: MIT Press, 2001), 401.

130 Bey, Hakim. The Temporary Autonomous Zone: Ontological Anarchy, Poetic Terrorism, http://www.to.or.at/ hakimbey/taz/taz.htm(Accesed April 1oth 2009) 
constrained by a government of surveillance. The $T A Z$ would be temporary and would dissolve upon its discovery, only to avoid becoming a part of the surveillance society. Later, however, in sight of more sustainable beliefs Bey introduced a modified concept - the Permanent Autonomous Zone(PAZ).

Despite the fictional delivery, Bey, tackles a tangible problem. He believes that a structured, hierarchical system would inevitably obstruct individual creativity and ability of self expression. The rebellion that he offers, is destined to never succeed, because succeeding will, once again, establishing an organized state. 


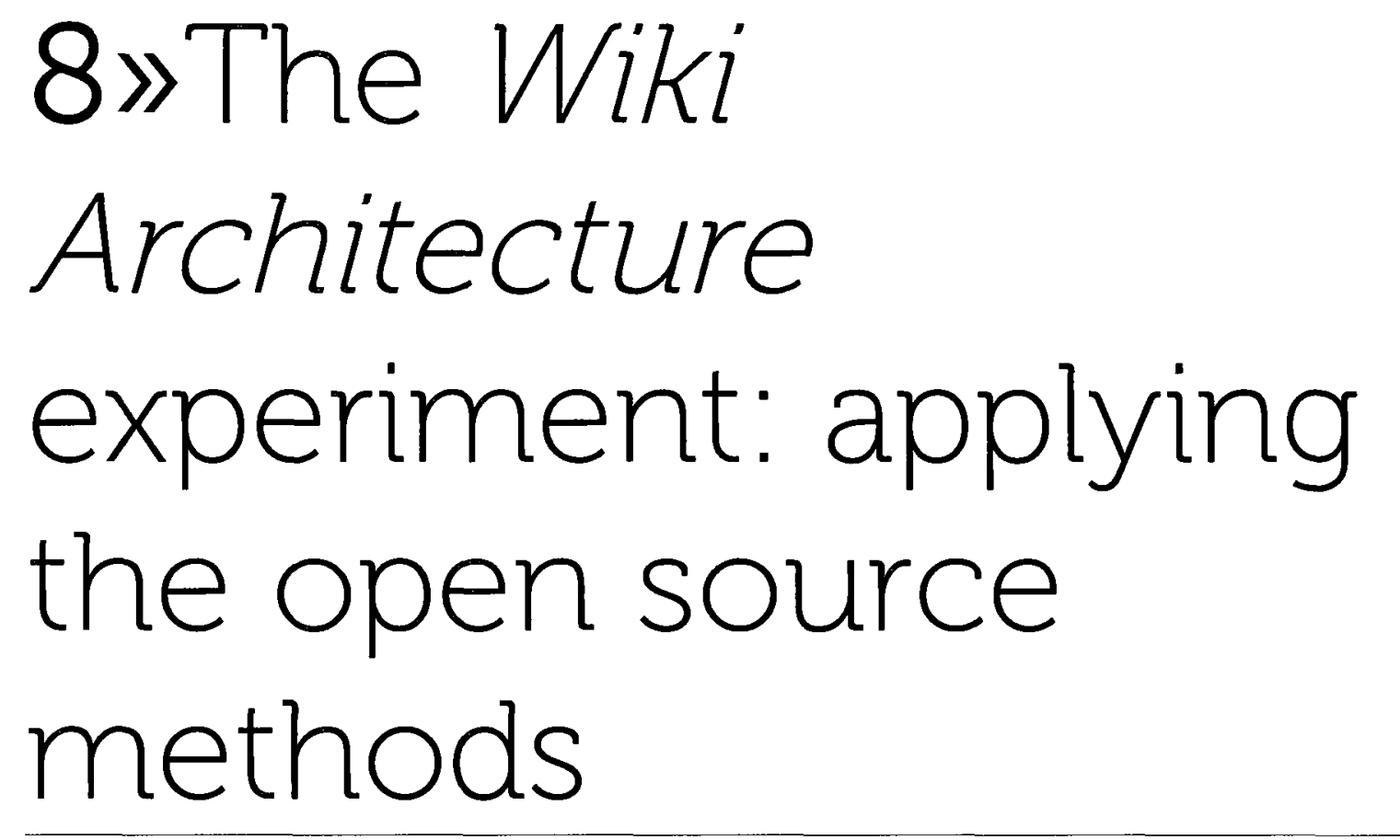

\footnotetext{
$\left\{\begin{array}{l}\text { This section treats wiki architecture as the experiment's subject, by expanding in } \\ \text { depth on the experiment's description, framework, components, and the technology } \\ \text { employed. }\end{array}\right.$
}

\section{1) The procedural and the anatomical approaches}

A project that investigates the open source movement to find possible applications in architecture may consider the following two strategies: anatomical and procedural. The first would focus on the mode of operation of open source and translate it into a diagrammatic formula, in which open source becomes the anatomy and the organizing principles of architectural spaces. The results would feature programmatic flexibility, previously explored by such architects as Richard Rogers and Renzo Piano in their Centre Georges Pompidou of 1970, Cedric Price and his Fun Palace of 1964, and Constant Nieuwenhuys from the

Situationist International who deigned his New Babylon in 1950 (Error: Reference source not 
found, Illustration 9, Illustration 10 respectively). Mark Wigley, an architect and architectural critic, points out that an even earlier example would be the Modernism, where "[f]or many modern architects it was the orthogonal grid itself that acted as the paradigm of the open nonhierarchical horizontal system extending infinitely..."131.

Conversely, the procedural approach does not attempt to abstract the open source model into architecture. It rather employs open source as an ad hoc medium to facilitate the design process. As a result, the projects remain open ended only throughout the design phase, allowing for collaboration to happen between the lead architect and others. Typically, the contributing bodies, who are architects or otherwise involved, all act upon their personal motives, while the project benefits from an array of inputs and critique. Recently, a number of research initiatives began to explore such procedural implementations, while gaining popular acclaim and attracting new contributors. In a number of cases, these were looking for possible housing solution that would prevent or withstand natural disasters. Cameron Sinclair, a co-founder of Architecture for Humanity $(A F H)$, developed a global humanitarian open source network "... where architects, governments and NGOs can share and implement design plans...[while]... offering innovative solutions to housing problems in all corners of the globe." ${ }^{132}$. Amongst some of the examples are the Siyathemba for South Africa, The Rural Center of Excellence in Tanzania, and the Biloxi Model Program to rebuild some parts of the city after hurricane Katrina.

Unfortunately, in some cases the anatomical approach has the tendency to turn into an architectural fetish rather than an organization principle. For instance, American architect and futurist, Buckminster Fuller "...devoted his career to modelling such three-dimensional networks and testing new ways of occupying them"133. He often would photograph himself

131 Wigley, Mark. "The Architectural Brain", in Network Practices, ed. by Anthony Burke, Therese, Tierney, (New York: Princeton Architectural Press, 2007), 32.

132 "Speakers. Cameron Sinclair: Co-founder, Architecture for Humanity", in TED, http://www.ted.com/index.php/speakers/cameron_sinclair.html (Accessed April 15 ${ }^{\text {th }}$, 2009) 133 Wigley, Mark. "The Architectural Brain", in Network Practices, ed. by Anthony Burke, Therese, Tierney, (New York: Princeton Architectural Press, 2007), 36. 
standing within modular steel framework and attempting to look comfortable (Illustration 11). Such explorations of inhabiting space frame architecture can be summarized as "... unconscious attempt to visibly model the invisible electronic networks that increasingly defined contemporary life"134. Unfortunately, the line between architecture and such architectural sculptures is thin. The latter is largely uninhabitable, and should remain strictly a representational medium. Open source translated into such superficial architecture avoids dealing with circulation, social interaction, program, and other uses that take advantage of its strengths.

Likewise, on its own the Procedural application takes only a limited advantage of the open source approach. It acts as a facultative ectosymbiosis - treating the aspect of collaboration as parasitic and an optional resource for the architects, rather than an integral dimension. The finalization of the designs often remains at the discretion of the architects in chief, regardless of the other parties' ambitions. Akin to software development, the architectural drawings, or in other words the source code of the building, remain redistributable but only as gained knowledge that could be used on a different occasion. However, upon construction these are of no relevance to the building itself. Like compiled code, there is no way back from the built into the drawing board. Also, while a software developer is free to use the open source code of a product to develop their own version of a program, having little obligations to the creator, the physical construction is available only to those in power or who has the resources to act. As a result, the architectural source remains open strictly “on paper”.

To truly explore the open source with respect to architecture it is necessary to create a synthesis, in which both - the anatomical and the procedural - applications coexist. Therefore, this paper describes two phases of one projects. The first phase attempts the procedural approach, while the latter ${ }^{135}$ will deal with the anatomical - built environment.

134 Wigley, Mark. "The Architectural Brain”, in Network Practices, ed. by Anthony Burke, Therese, Tierney, (New York: Princeton Architectural Press, 2007), 33. 135 N.B. The anatomical approach is discussed in the following chapter - 9" The White House Redux project, page No. 86. 


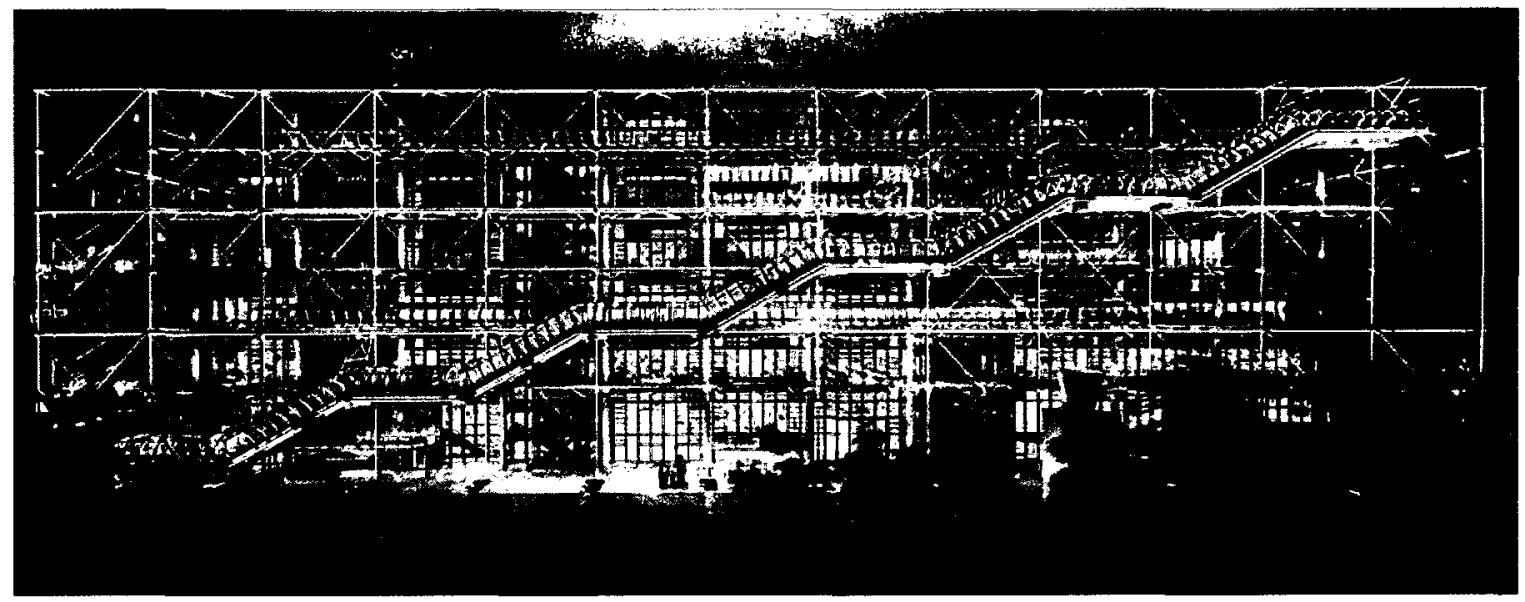

Illustration 8: Centre Georges Pompidou

Source: Troelsen. Thomas, Asger Tarpgaard, Tanja Simonsen. "Centre Georges Pompidou", in Private, $h t t p: / / w w w$.weareprivate.com/blog/?p=732 (Accessed April 15 $5^{\text {th }}, 2009$ )

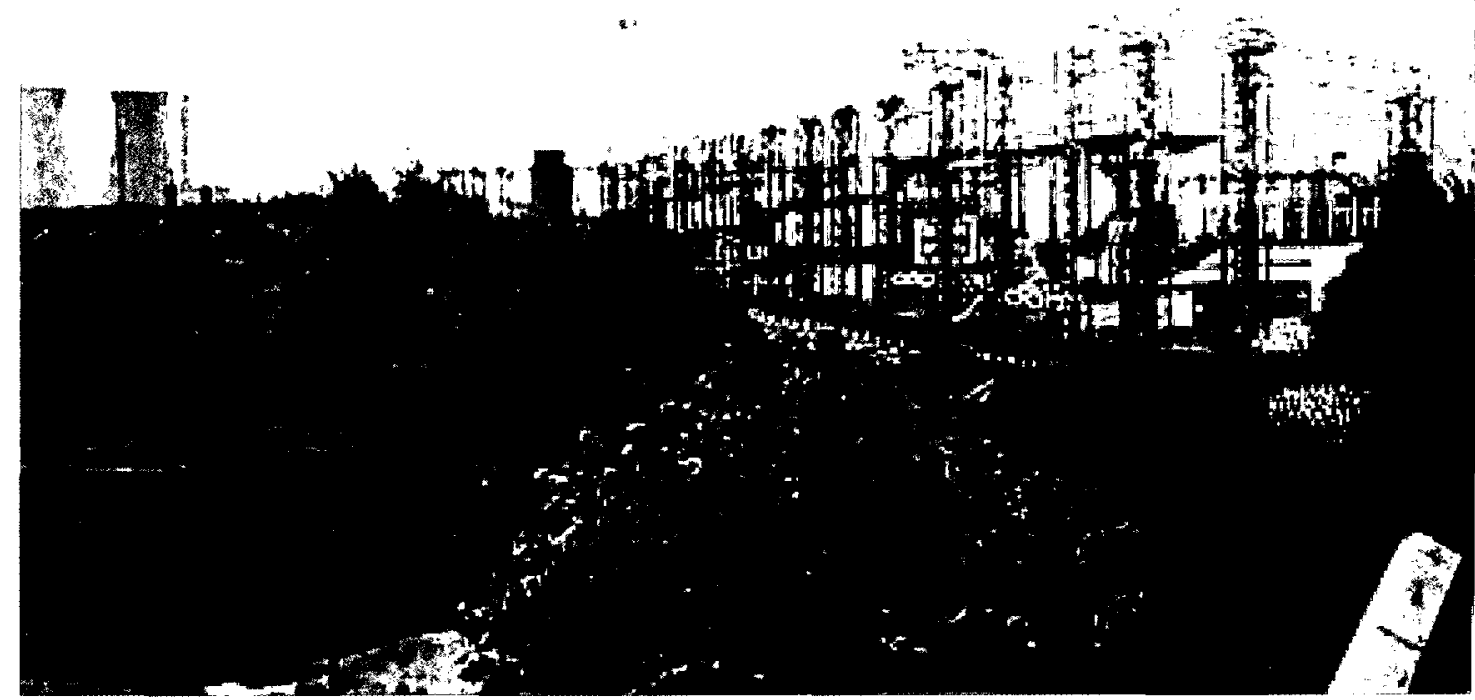

Illustration 9: Fun Palace

Source: Wigley, Mark. "The Architectural Brain", in Network Practices, ed. by Anthony Burke, Therese, Tierney, (New York: Princeton Architectural Press, 2007), 41. 


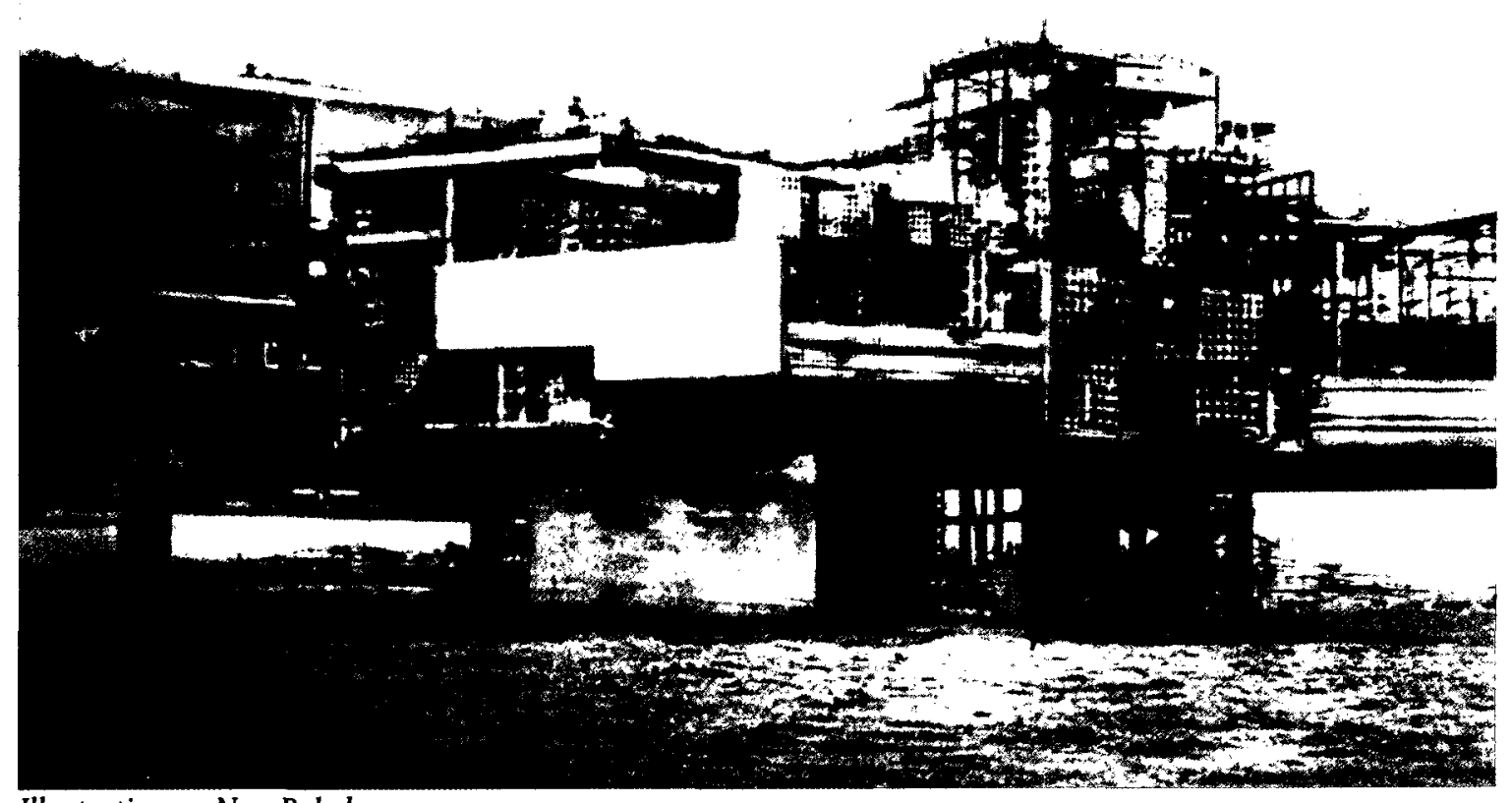

Illustration 10: New Babylon

Source: Manaugh, Geoff. "The possibility of secret passageways: An Interview with Patrick McGrath", in BLDG Blog, http://bldgblog.blogspot.com/2007_07_oi_bldgblog_archive.html (Accessed April 15 $5^{\text {th }}$, 2009) 


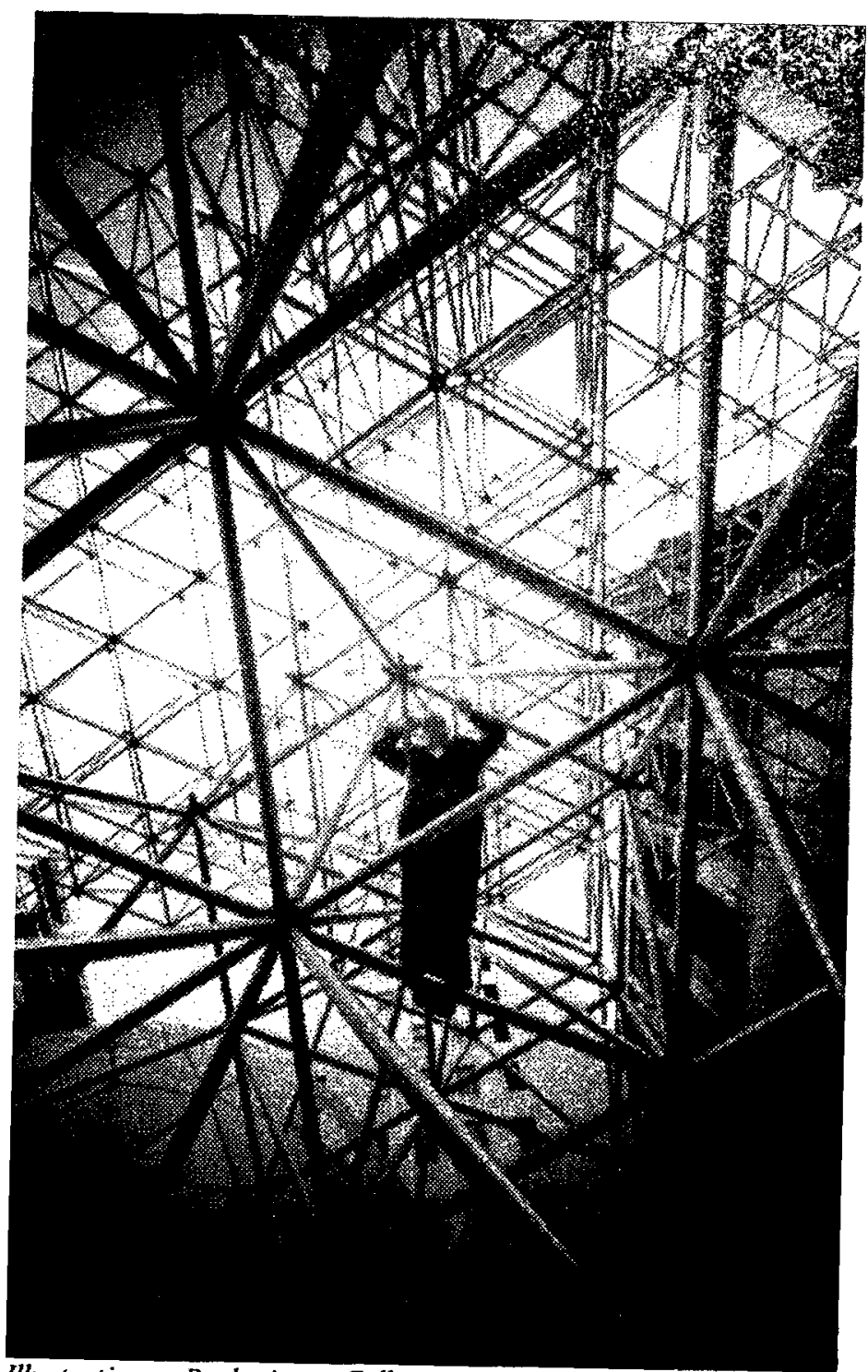

Illustration 11: Buckminster Fuller standing inside modular steel framework

Source: Wigley, Mark. "The Architectural Brain", in Network Practices, ed. by Anthony Burke, Therese, Tierney, (New York: Princeton Architectural Press, 2007), 37. 


\section{2) The procedural approach}

The Wiki Architecture experiment at its core makes use of a variation of collaborative Internet software called wiki, which was specifically designed for project management, where documentation is intended to be coauthored by multiple parties. Like many other wiki software, Wiki Architecture was originally intended for the management of software and textual information. However, in order to make it applicable for this project, the wiki was heavily customized and refashioned, keeping in mind such important aspects as usability, accessibility, and intuitive operability. The content managed in Wiki Architecture is typical professional documentation used in describing an architectural preposition, including: drawings, blueprints, programmatic requirements, conceptual sketches, theoretical background, three dimensional computer models, photographs of the site and physical models, maps, wind and light studies, diagrammatic information and many more.

As a result, the $w i k i$ in its current state is an interactive portal to the design process of this thesis. The documentation of the proposed built environment as well as the written portion of this paper are both entirely exposed to criticism, commentary, and alteration by whomever has access to the Internet. It is an architectural free-for-all, where everyone can collaborate, borrow, and contribute, regardless of one's occupation and abilities. All of the editing progress is made transparent, documented, and reversible by the very nature of the wiki software. In this environment not only the architectural design evolves in a collaborative manner, but the very subject of evolution is observable landing to a better understanding and analysis.

Finally, it is important to note that the project is an ongoing process, which could continue well beyond the timely scope of this thesis, and well beyond the scope of its purpose, due to its liberal nature, and nature of the wiki software used. 


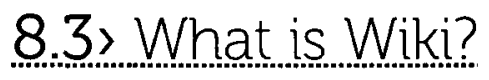

Today, most of the growing interest in the wikis comes from the success and popularity of Wikipedia - a free Internet encyclopedia that relies solely on the contribution of its users to enter and edit information. Since the launch in 2001, Wikipedia has grown to include nearly three million entries in the English language only, and over sixteen million entries overall. ${ }^{136}$

Although, Wikipedia is the most popular wiki application on the Internet web, it is not the first one and definitely not the only one. The original wiki was built by an American computer programmer Howard G. "Ward" Cunningham in 1995. It was designed for a Web site titled Portland Pattern Repository in an attempt to allow for an easy exchange of ideas between computer programmers. At the time it was called WikiWikiWeb and in its essence was a database ${ }^{137}$ of programming code snippets that members of the site could expand by using it in a similar fashion to today's Wikipedia. Cunningham is often quoted stating that wiki is "The simplest online database that could possibly work"138, implying that in a wiki people would interact and produce content in much the same way as they would if they were to work in person - using dialogue and common scene. In Bo Leof $s^{139}$ and Ward's own words:

"Wiki is a piece of server software that allows users to freely create and edit Web page content using any Web browser. Wiki supports hyperlinks and has a simple text syntax for creating new pages and crosslinks between internal pages on the fly.

Wiki is unusual among group communication mechanisms in that it allows the organization of contributions to be edited in addition to the content itself.

Like many simple concepts, "open editing" has some profound and subtle effects on Wiki usage. Allowing everyday users to create and edit any page in a Web site is exciting in that it encourages democratic use of the Web and promotes content composition by nontechnical users." ${ }^{140}$

136 Wikipedia, http://en.wikipedia.org/wiki/Main_Page (Accessed April $16^{\text {th }}, 2009$ )

137 N.B. A database is a structured collection of records and/or other information that is stored in a computer system.

138 Cunningham, Ward, Bo Leuf. Wiki.org, http://wiki.org/wiki.cgi?WhatIsWiki (Accessed April $16^{\text {th }}, 2009$ ) 139 N.B. Ward Cunningham's consultant and coauthor of the book The Wiki Way:Quick Collaboration on the Web, 2003 140 Cunningham, Ward, Bo Leuf. Wiki.org, http://wiki.org/wiki.cgi?WhatIsWiki (Accessed April 16 ${ }^{\text {th }}$, 2009) 
Every wiki includes a variant of an "edit" link, which allows visitors to make immediate changes to the displayed page. This feature sets wikis apart from any other Web pages, blogs ${ }^{141}$, or other Internet resources, where the user is only capable of retrieving content and occasionally leaving feedback to the author. In a wiki every reader is also an author who is free to leave feedback, mark content for a dispute, alter content, and introduce new information. In simple terms, a typical web page is only of use to individual authors, or a hierarchal practice, while $W i k i$, is a tool for a community that wants to collaborate, akin to a boardroom or a blackboard.

Creators of a wiki applications generally refrain from placing a built-in structure, a roadmap, or a preconceived purpose in order to allow the content and patterns of use to dictate and selforganize the information internally. This often results in a complex, non-linear, and organic growth, that could be characterized as heterarchical, or "human".

Values cherished in wikis are reminiscent of the open source philosophy, and for a good reason. Wikis are very often built as open source applications, that get reproduced and hosted independently by volunteers. In some cases wikis are of such a loose structure that "child" wikis could be produced from within the wiki interface. MotherWiki and OddWikki, in fact, encourage their "children" to leave. ${ }^{142}$ However, not all wikis are open source. Recently, due to the escalating popularity of this phenomenon many proprietary software developers have introduced "closed" solutions in an attempt to benefit from this new market niche (i.e. PBWiki, Zoho Wiki, SamePage, etc.).

Since wikis are a novelty, they are often a source of misunderstanding. It is unclear who controls the well being of the content within them. They are vulnerable and prone to vandalism by anyone, in theory. However, in practice, these incidents rarely occur. The people who invest their time in the content generation would not damage wikis, while those with no 
interest would rarely care enough to act destructively. Moreover, any change, or deletion, for that matter, are simply reversible and tire anyone who would attempt to repeatedly vandalize. Nevertheless, in some instances wikis are made open only to a limited community of members as a precautionary measure.

\section{4) Description of the Wiki Architecture's assembly}

While the issue of collaborative design in architecture is subjected to a lengthy debate revolving around the concept of authorship, the possibility of utilizing the Internet's technologies in the same manner is nearly an uncharted territory. Therefore, the layout and infrastructure of the resultant Wiki Architecture Web page, which were created to complement this thesis, are products of an intuitive design. Without having a lot of precedent knowledge, it was difficult to form a general design strategy, in which all the necessary collaborative technologies would have delivered optimal results. Neither it was possible to conceive of a kind of a user interface that would facilitate a more intensive collaboration. These aspects of ergonomics are new to the field of network practices and are even more so in the field of collaborative architectural design.

Thusly, the wiki was constructed to introduce a reference point for understanding and reflecting upon collaborative behaviour. All of it's original parts were built using an educated guess that was based on the scarce precedent base that was available at the time of conception (i.e. Open Source Architecture for Africa ${ }^{143}$, and Studio Wikitecture $\left.{ }^{144}\right)$. Moreover, all of the components of the wiki have been arbitrated for effectiveness and continually optimized to enhance it's productivity as the project went along.

\section{少}

143 N.B. Can be accessed at http://www.osafa.org/english/Home (Accessed April 16 ${ }^{\text {th }}$, 2009) 144 N.B. Can be accessed at http://www.studiowikitecture.com or http://studiowikitecture.wordpress.com/ (Accessed April 16 ${ }^{\text {th }}$, 2009) 
Most of the efforts invested into Wiki Architecture were applied towards the reconstruction of the original user interface. In the default state, what was indented as tools for management of textual and pictorial information was suitable only as a medium for discourse. It satisfied only one half of the design process, as an architectural design rarely can be fully explicated verbally. The wiki platform used in this experiment is called Wikidot ${ }^{145}$. It features a set of tools that allow to freely share, upload, and delete heterogeneous - non-textual or non-pictorial - files. In Wiki Architecture this became the main conduit for the design, whereas, the user interface(UI) was centred around this feature making the file sharing handles as clear and visually accessible as possible. The illustrations 12 and 13 bellow offer two snapshots of the changes made to the wiki's UI, from the default design of the wiki to the current version. For visual simplicity and intuitiveness, the new interface was divided into three panes. The leftmost was designated for the navigation handles, where different pages of the wiki could be accessed. The centrepiece was specified for the contents of the pages. And, the rightmost pane was designated to showcase three editing options: files - allowing to upload and download content, edit, and add of the pictorial and textual content. The links on the right pane lead to three main areas of the wiki: about (Illustration 14 and 8) - containing introductory information about the experiment, notes on the tools available to users, and a general roadmap; playgound (Illustration 15, 16, and 17) - holding the design progress in a chronological order, including every submission and alteration made; and forum (Illustration 18) - where the general discourse over the design process takes place. Additionally, a smaller(to chiefly encourage the focus on the design) link was provided on the left pane leading to the thesis' written portion - a version of which you are reading at the moment.

The design material was mainly held within files containing computer generated three dimensional models. These were formats intended for use in the programs SketchUP and

145 N.B. Can be accessed an http://www.wikidot.com 
Blender. Since, both programs are freely available, and Blender is an open source application, attainability of these resources to all users was guaranteed.

Finally, for online viewing the Wiki Architecture can be accessed at http://arch1k.wikidot.com/ . 


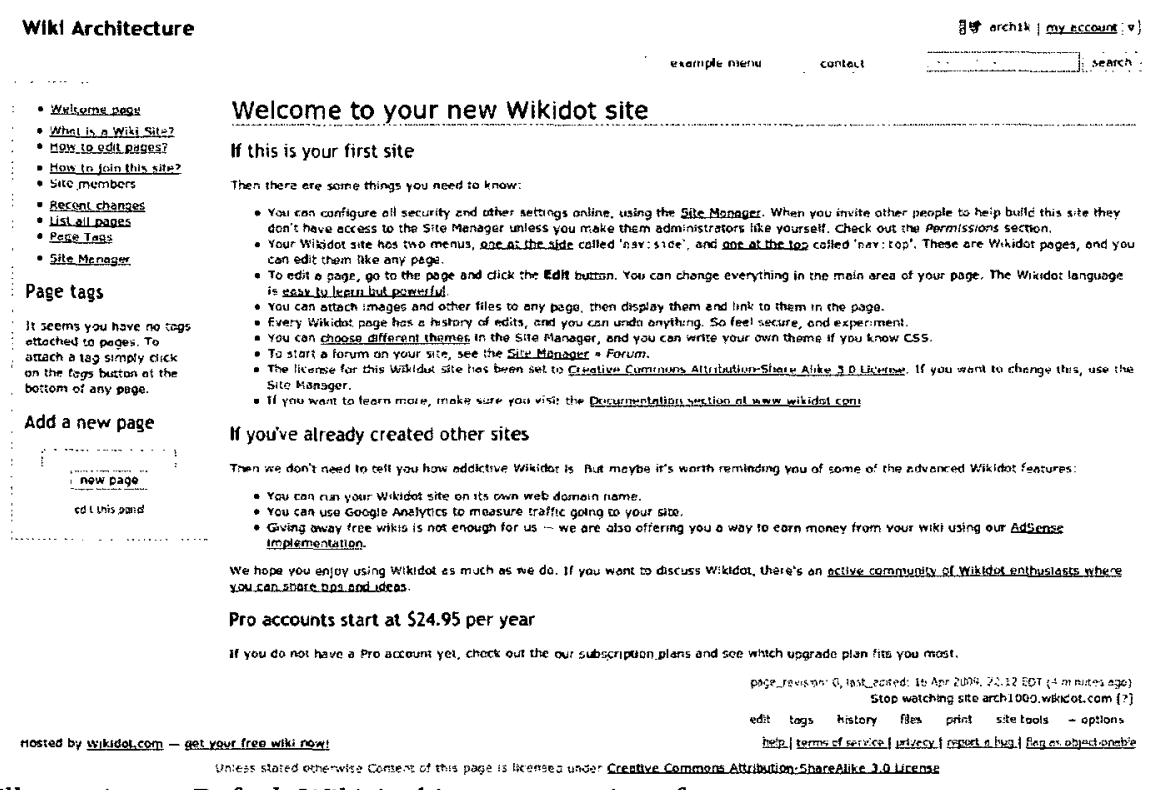

Illustration 12: Default Wiki Architecture user interface 


\section{About Playground Forum

$\square$
$\square$

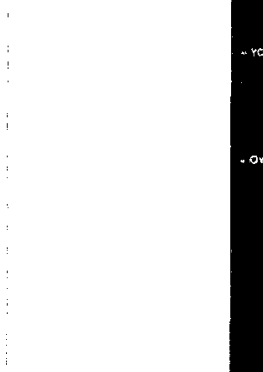

Comments

god a ner conshert:

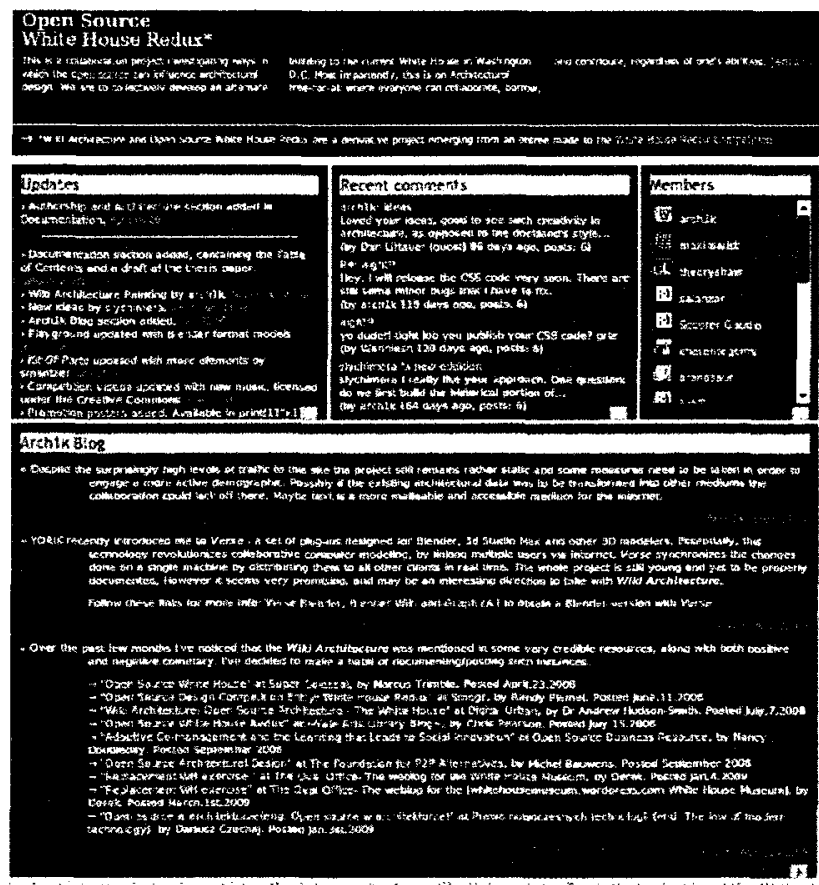

ariles

$X$ Add

$X E$ dit

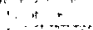

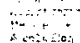

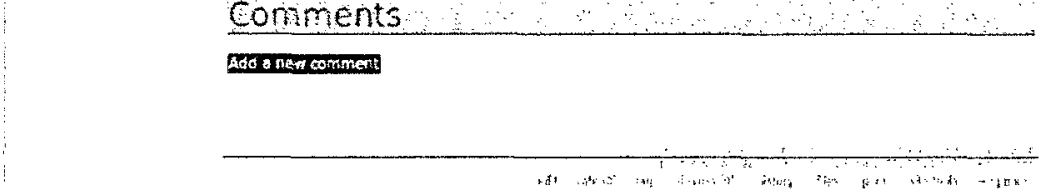

Illustration 13: Current Wiki Architecture user interface 
wiki architecture

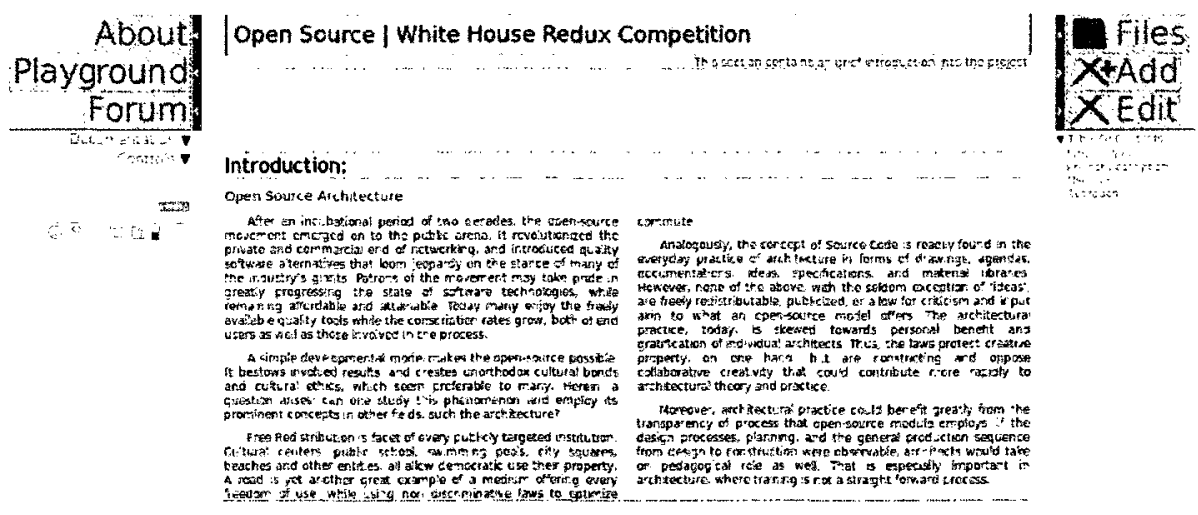

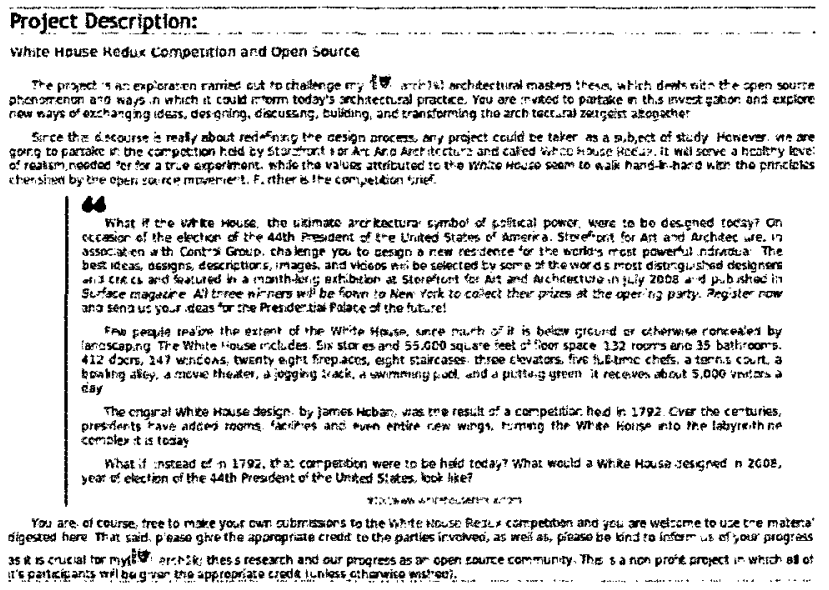

Illustration 14: Wiki Architecture "About" section (part 1 of 2) 

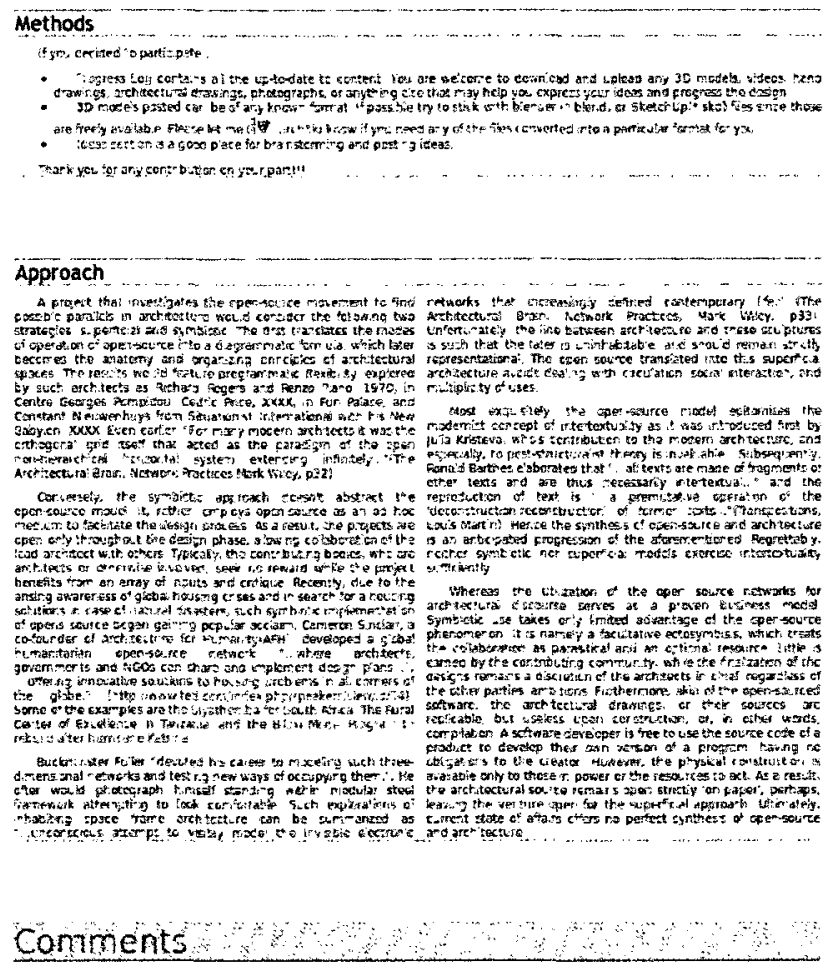

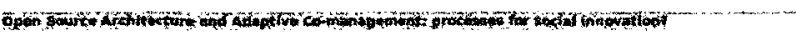

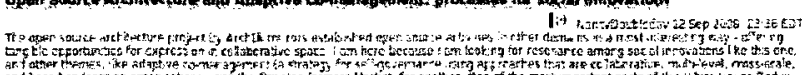

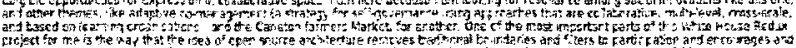

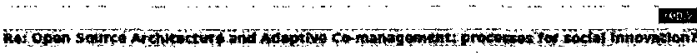

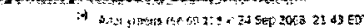

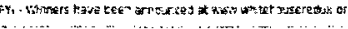

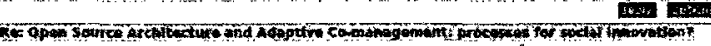

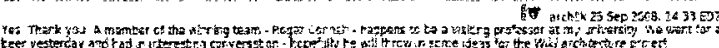

Ean Exas

Ast your cemmers

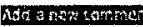

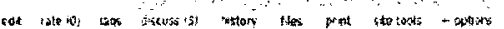

Illustration 15: Wiki Architecture "About" section (part 2 of 2) 


\section{wiki arcfirtecture}

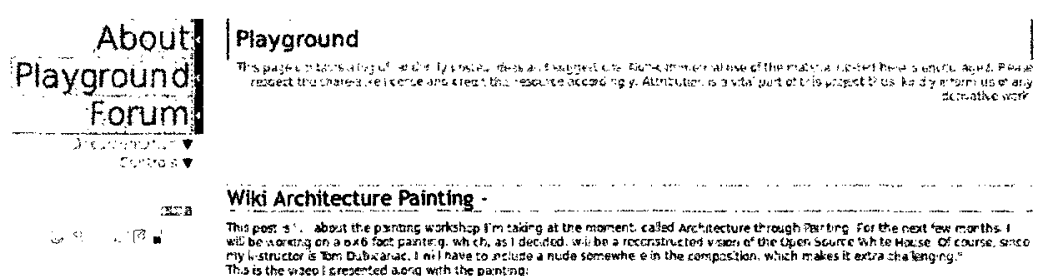
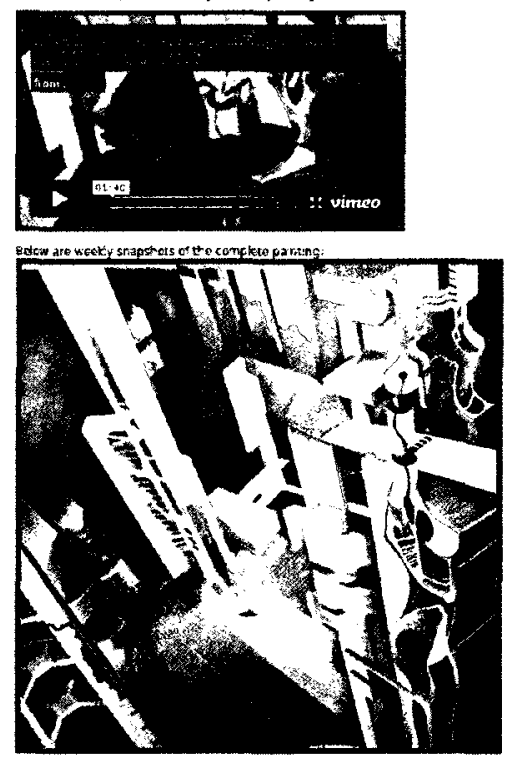

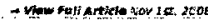

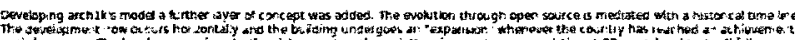

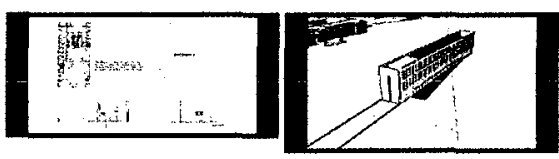

oet $27 \mathrm{zh}=\mathrm{z}=\mathrm{O}$

Source files:

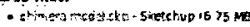

Illustration 16: Wiki Architecture "Playground" section (part 1 of 3) 


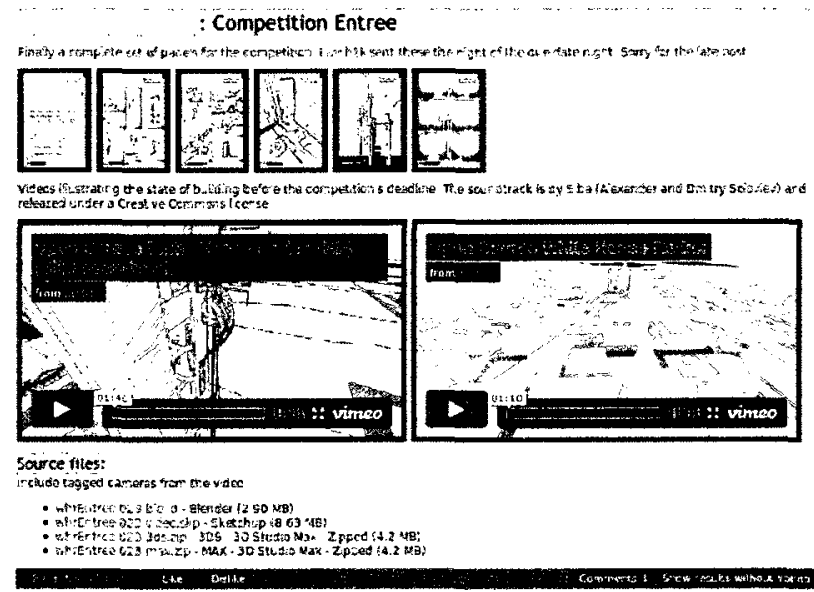

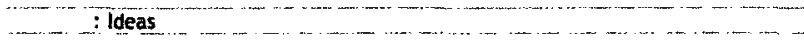

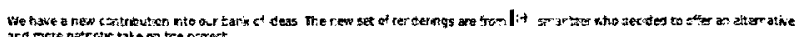
国国国照 sourcetion

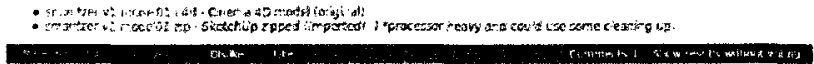
ideas

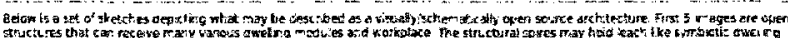

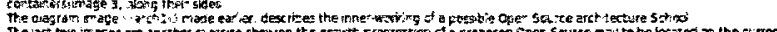

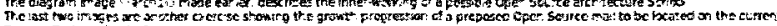

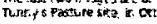

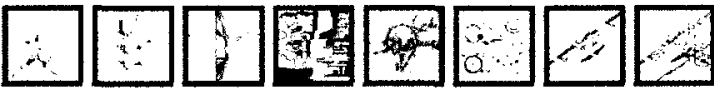

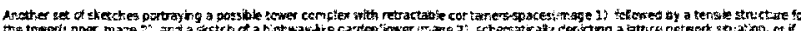

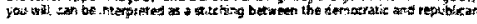

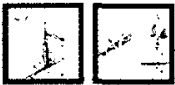

Illustration 17: Wiki Architecture "Playground" section (part 2 of 3) 


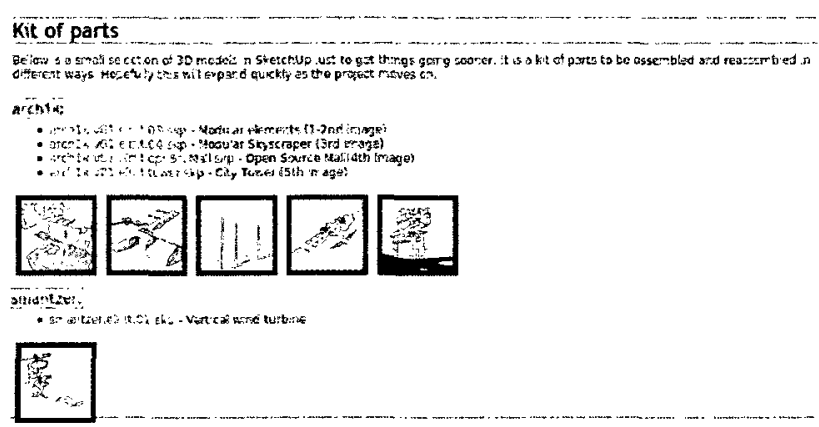

Site

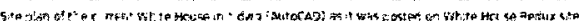

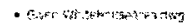

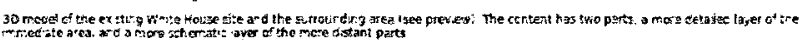

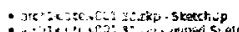

: O.

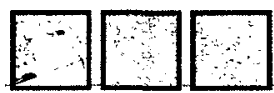

Comments

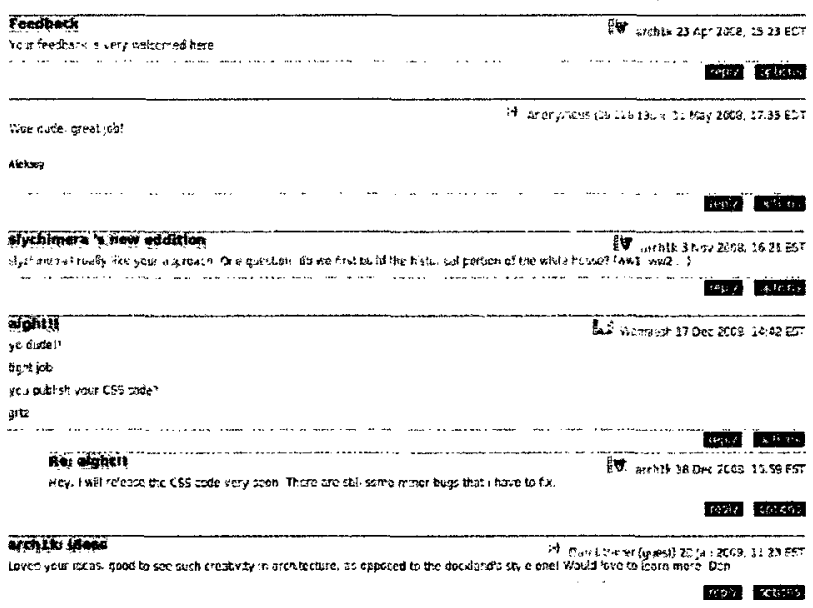

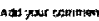

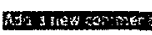

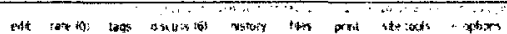

Illustration 18: Wiki Architecture "Playground" section (part 3 of 3 ) 

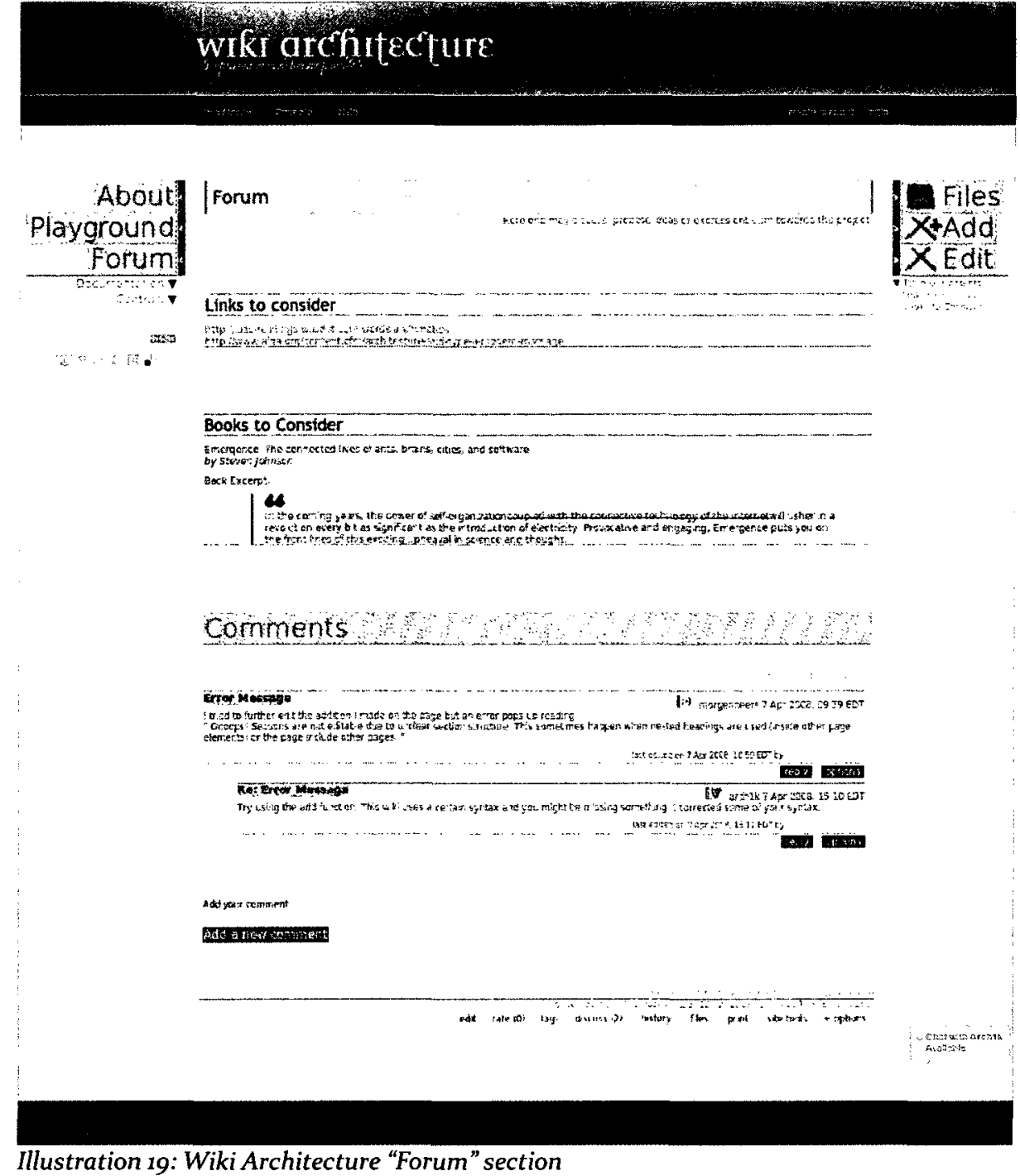

Wiki Architecture $\cdot 79$ 


\section{5) Promotional material}

In order to promote the project a number of initiatives were taken. Firstly, the wiki was made searchable on multiple search engines using associative key terms (i.e. Open source, architecture, wiki etc.). Secondly, it was promoted amongst key architectural Internet portals (i.e. Archinect.com, BLDGBLOG.blogspot.com, vimeo.com architectural groups etc.). Lastly, a multitude of promotional posters were printed and distributed within the Carleton University, University of Toronto, Ryerson University, OCAD, and generally within the city of Ottawa and Toronto's creative domains (see examples of posters bellow: ). 
$>$ Is open source architecture possible?

wIRIarchitecture

\section{arch1k.wikidot.com}

Open Source

White House Redux *

This is a collaboration project that explores ways in which architectural design can be influenced by the open source development model.

We are to collectively design an alternate building to replace the current White House in Washington D.C.

Most importantly, the project is an Open Source Architectural free-for-all where everyone can collaborate, borrow, and contribute ideas regardless of their occupation.

*Wiki Architecture and Open Source White House Redux is a derivative project coming from an entree made to the White House Redux Competition carried out by Storefront For Art And Architecture (http://www.storefrontnews.org/)

eMail: arch1000@gmail.com

Illustration 20: Wiki Architecture promotional poster (eMail version) 


\title{
WIRIarchitecture
}

$>$ Is open source architecture possible?

\section{arch $1 \mathrm{k}$. wikidot . com}

Open Source

White House Redux

This is a collaboration

project that explores ways

it which arehitectural

design can be intluenced by

the open souree

development model.

We are to collectively

design an alternate building

to replace the curren

to rcplace the curce

Washington D.C.
Most importantly, the

project is an Open Source

Arehitectural frec-for-all

where everyone can

collabonte, borrow, ind

contribute ideas regardless

of their occupation.

eMail: archlooo@gmail.com

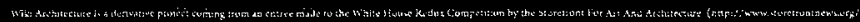

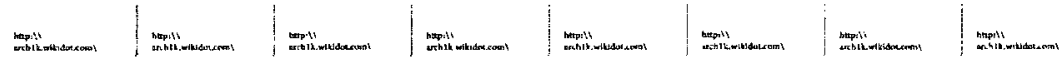

Illustration 21: Wiki Architecture promotional poster No.1 (version for print)

\section{Architecture Wiki}

\author{
$>$ is open soure archimecture possible?
}

\section{hat arch1k , wikidot . com}

White House Redux

\begin{tabular}{|c|c|c|}
\hline 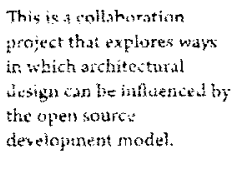 & 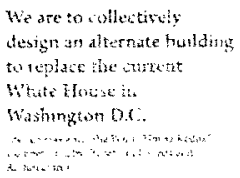 & 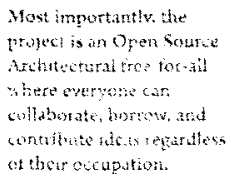 \\
\hline
\end{tabular}

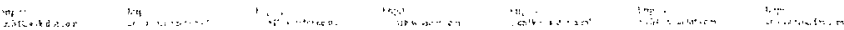

Illustration 22: Wiki Architecture promotional poster No.2 (version for print) 


\section{6) Publicity}

Since Wiki Architecture is managed without a budget its promotion relies largely on word of mouth communication. This is generally the trend in the open source community, where their is simply no room for publicity in the budget. Herein, recognition by the active community becomes an adequate gauge for success, a proof of viability. Over the period of two years of the Wiki Architecture's existence the project has been mentioned numerously amongst some credible sources, along with both positive and negative commentary. Below are a number of examples of such reviews.

$\rightarrow$ "Open Source White House" at Super Colossal, by Marcus Trimble. Posted April.23.2008

(http://supercolossal.ch/2008/04/23/open-source-white-house/), accessed April 16 $6^{\text {th }}, 2009$

You may be aware of the competition organised by the Storefront for Art and Architecture to redesign the White House. Well, one team is preparing an open source entry. "You are invited to partake in this investigation and explore new ways of exchanging ideas, designing, discussing, building, and transforming the architectural zeitgeist altogether."

$\rightarrow$ "Open Source Design Competition Entry: White House Redux" at Smogr, by Randy Plemel. Posted June.11.2008

(http://smogr.com/2008/06/open_source_design_competition_entry_white_ho.html), accessed April 16 ${ }^{\text {th }}, 2009$

Edward Solodukhin's thesis project, Open Source | White House Redux Competition, explores the role of open source by creating and submitting an entry to the White House Redux competition, a competition to redesign the White House (winners to be announced shortly). It is hard to tell how many different people worked on the entry, shown above and at the top of the process page.

The process and procedural notions of an open source are intriguing, and worth study even if visions of Christopher Alexander's Pattern Language bleed into the margins. Unfortunately it appears that Solodukhin faced a situation many open source projects face: a lack of critical mass which sustains and metamorphosis into a self-regulating and perpetuating process. 
$\rightarrow$ "Wiki Architecture: Open Source Architecture - The White House" at Digital Urban, by Dr Andrew Hudson-Smith. Posted July.7.2008

(http://digitalurban.blogspot.com/2008/07/wiki-architecture-open-source.html), accessed April $16^{\text {th }}, 2009$

The movies above and below are part of a collaboration project investigating ways in which the open source can influence architectural design. The project aims to collectively develop an alternate building to the current White House in Washington D.C. Perhaps more importantly, this is an Architectural free-for-all where everyone can collaborate, borrow, and contribute, regardless of one's abilities. [...]It an interesting concept and one that we applaud - take a look at http://archik.wikidot.com/ for full details and how to take part. Also take a look at our posts on Wikitecture - a similar idea taking place in Second Life.

$\rightarrow$ "Open Source White House Redux" at Yale Arts Library Blog , by Chris Pearson. Posted July.15.2008 (http://artslibrary.wordpress.com/2008/07/15/open-source-white-houseredux/), accessed April $16^{\text {th }}, 2009$

Digital Urban is reporting on White House Redux, a collaborative architecture project that seeks to collectively redesign the White House in Washington, D.C. [...] Read about another collaborative architecture project taking place in Second Life here and here. And for more, see the Open Architecture Network as well as the Library Design Wiki.

$\rightarrow$ "Adaptive Co-management and the Learning that Leads to Social Innovation" at Open Source Business Resource, by Nancy Doubleday, Carleton University, department of geography professor. Posted September.2008

(http://www.osbr.ca/ojs/index.php/osbr/article/viewArticle/702/670), accessed April 16 ${ }^{\text {th }}$, 2009

[...]Edward G. Solodukhin positions his architecture project in the world of open source[...]This is a student-defined project that applies the open source approach to the field of architectural design. As both a process and product of open source development, this project lends support to an argument for viewing open source conceptually and concretely as a source of social innovation in learning environments. It illustrates that open source is a powerful force capable of creating social innovation in fields other than the software development domain.

[...]The architecture project is an example of social innovation across scales. First, in the larger context, it is an initiative to collaboratively re-design an alternative to the White House. Second, at the level of the individual, it is a graduate project by 
Edward Solodukhin who embraced this different form of architecture represented in the larger context, and acted autonomously. His reflexive and creative response is to leverage the opportunity for public design by adopting open source as a model for his architectural design project.

$\rightarrow$ "Open Source Architectural Design" at The Foundation for P2P Alternatives, by Michel

Bauwens. Posted September.2008

(http://p2pfoundation.net/Open_Source_Architectural_Design), accessed April 16 ${ }^{\text {th }}, 2009$.

The article quotes Nancy Doubleday's report.

$\rightarrow$ "Replacement WH exercise" at The Oval Office- The weblog for the

[whitehousemuseum.wordpress.com White House Museum], by Derek. Posted

March.1st.2009 (), accessed April 16 $6^{\text {th }}, 2009$

This is an interesting video done, apparently, as an architecture-school exercise in replacing the WH with a new structure. In this case, the structure chosen was a couple of elevator shafts and a staircase, I guess. [...]This related site is about opensource (brick-and-mortar) architecture but uses a new WH as its central exercise. [...] This calls to mind a thought experiment. Since the capital was not moved to Cincinnati after the 1814 fire, we have a capital that sits at the extreme east of the nation. Some presidents have maintained a "Little White House" or "Western White House," primarily as vacation getaways, but do we need a genuine "Western White House" for the president to sometimes work out of and what would it look like?

$\rightarrow$ "Open source w architekturze(Fro Polish - Open source w architekturze)" at Prawo

nowoczesnych technologii (The law of modern technology)- by Dariusz Czuchaj. Posted

Jan.3st.2009 (), accessed April 16 ${ }^{\text {th }}, 2009$. Written in Polish.

Czy projekty Open Source mają przyszłość w takiej dziedzinie jak architektura? Można sprawdzić to osobiście na sajcie Wiki Architecture. Ciekawy pomyst, ciekawe co z nizebywalnymi według polskiego prawa osobistymi prawami autorskimi. Zobowiazać się do ich niewykonywania czyli obejść prawo (nieważna czynność prawna) ? A może czas zmienić prawo zezwalając twórcy na podjęcie decyzji co do jego praw i przekazania ich do domeny publicznej ? 


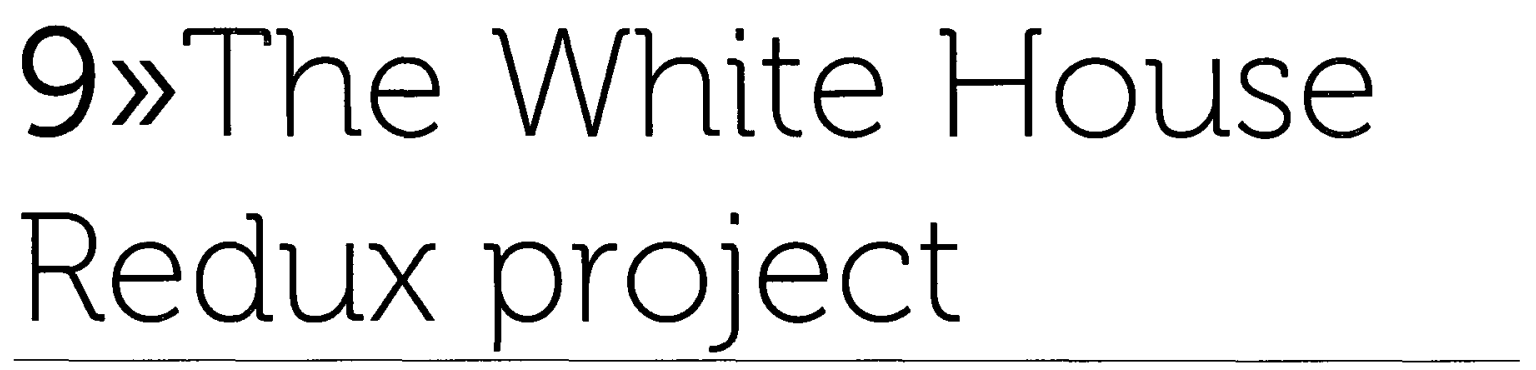

$\left\{\begin{array}{l}\text { This section treats the wiki as a generative tool, where the subject of discussion is it's } \\ \text { very product. Included are: concept, presentation drawings, 3d models, and other } \\ \text { references. }\end{array}\right.$

When Wiki Architecture was under way, an architectural project was necessary to become the subject of the design process within the wiki. For that matter the assignment took advantage of a competition, which was carried out by Storefront for Art and Architecture at the time. An introductory page on Wiki Architecture includes a brief which explicates the purpose of the wiki and introduces the competition. Herein, is the content of the brief:

This project is an exploration carried out to challenge my architectural masters thesis, which deals with the open source phenomenon and ways in which it could inform today's architectural practice. You are invited to partake in this investigation and explore new ways of exchanging ideas, designing, discussing, building, and transforming the architectural zeitgeist altogether.

Since this discourse is really about redefining the design process, any project could be taken as a subject of study. However, we are going to partake in the competition held by Storefront for Art and Architecture and called White House Redux. It will serve a healthy level of realism, needed for a true experiment, while the values attributed to the White House seem to walk hand-in-hand with the principles cherished by the open source movement. Further is the competition brief:

"What if the White House, the ultimate architectural symbol of political power, were to be designed today? On occasion of the election of the 44 th President of the United States of America, Storefront for Art and Architecture, in association with Control Group, challenge you to design a new residence for the world's most powerful individual. The best ideas, designs, descriptions, images, and videos will be selected by some of the world's most distinguished designers and critics and featured in a monthlong exhibition at Storefront for Art and Architecture in July 2008 and published in Surface magazine. All three winners will be flown to New York to collect their prizes at 
the opening party. Register now and send us your ideas for the Presidential Palace of the future! $!^{3 / 46}$

"Few people realize the extent of the White House, since much of it is below ground or otherwise concealed by landscaping. The White House includes: Six stories and 55,000 square feet of floor space, 132 rooms and 35 bathrooms, 412 doors, 147 windows, twenty-eight fireplaces, eight staircases, three elevators, five full-time chefs, a tennis court, a bowling alley, a movie theater, a jogging track, a swimming pool, and a putting green. It receives about 5, ooo visitors a day.[...]The original White House design, by James Hoban, was the result of a competition held in 1792. Over the centuries, presidents have added rooms, facilities and even entire new wings, turning the White House into the labyrinthine complex it is today.[...] What if, instead of in 1792, that competition were to be held today? What would a White House designed in 2008, year of election of the 44th President of the United States, look like? ${ }^{m_{47}}$

You are, of course, free to make your own submissions to the White House Redux competition and you are welcome to use the material digested here. That said, please give the appropriate credit to the parties involved, as well as, please be kind to inform us of your progress as it is crucial for my(archik) thesis research and our progress as an open source community. This is a nonprofit project in which all of its participants will be given the appropriate credit (unless otherwise wished).

\subsection{Site of the project}

Site of the existing White House was reconstructed in a computer modelling software and made available for the members of the wiki. Bellow is a snap shot of the current three dimensional model rendered in SketchUP.

146 White House Redux, http://www.whitehouseredux.com/Home (Accessed April 16 ${ }^{\text {th }}$, 2009) 147 White House Redux, http://www.whitehouseredux.com/Call-for-ideas (Accessed April 16 $6^{\text {th }}, 2009$ ) 


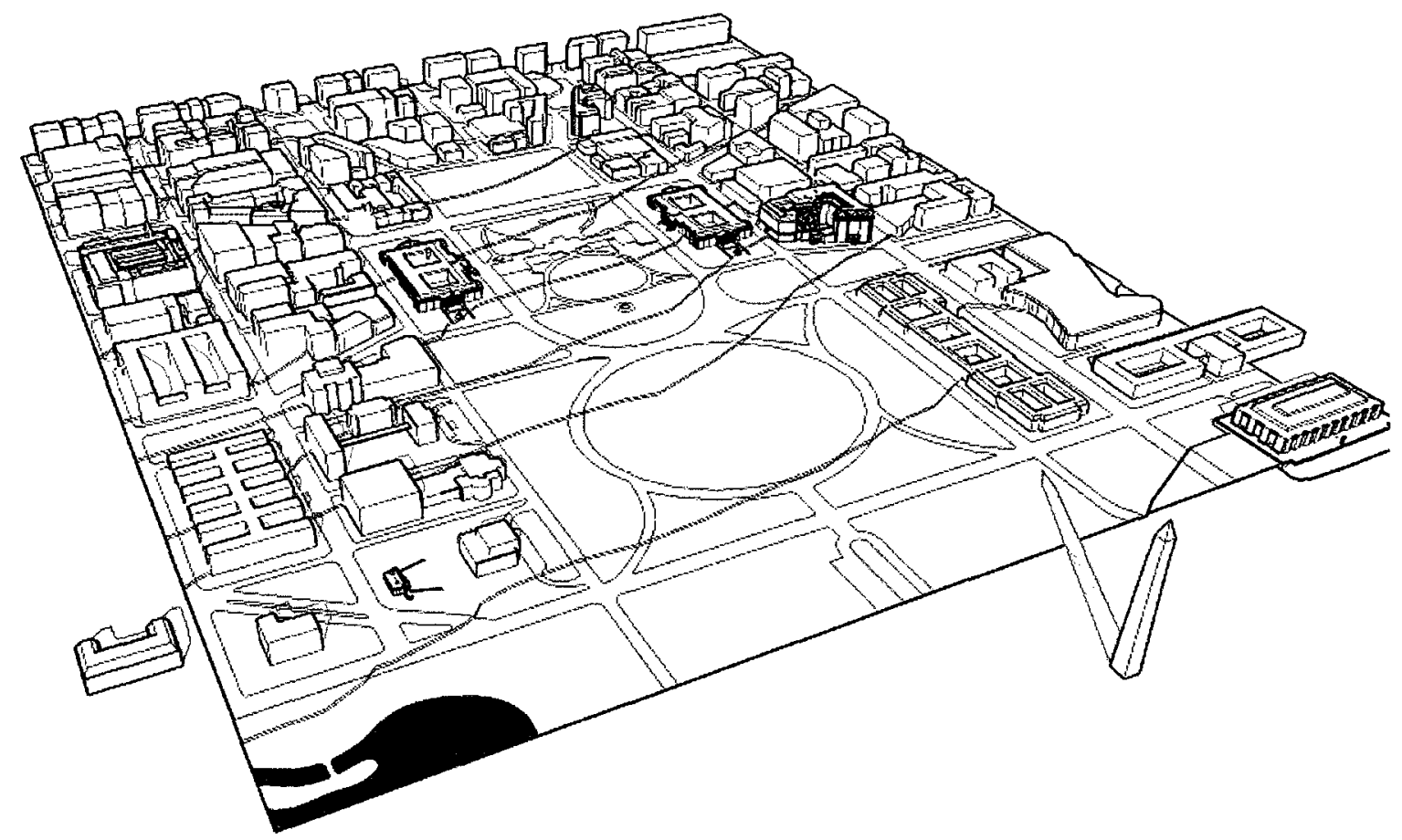

Illustration 23: White House Situation. Rendering of a three dimensional model. 


\section{2) Personal submission: the anatomical approach}

In order to initiate the design process within the Wiki Architecture a small selection of three dimensional models was designed at first in SketchUP software and made available (see Illustration 19 through 21). These were simple modular elements that could be assembled in a number of ways and were intended as a minimal kit-of-parts. This kit was to introduce a starting point for the collaboration, and was expected to expand from there on.

However, the competition's deadline was near exhaustion while the project was only beginning to gain momentum.

In order to meet the emerging due date, I decided to make a personal submission to White bouse Redux, using the material that was readily available on the wiki. At my disposal were the original kit-of-parts and some newly published material generated by two of wiki's newcomers. The intention was to make the submission and all of its deliverables available as part of the wiki. From this point, the project became independent from the White House Redux competition's deadlines and continued evolving in hope for more tangible results.

The concept that embodied the personal design solution was to translate the open source ideals governing the wiki into a building using what was earlier described as an anatomical approach. The building was to embrace open source by placing an emphasis on flexibility and openness throughout the program, aesthetics, and the freedoms of inhabitants (as these were expected to have control over the design after it was constructed). 


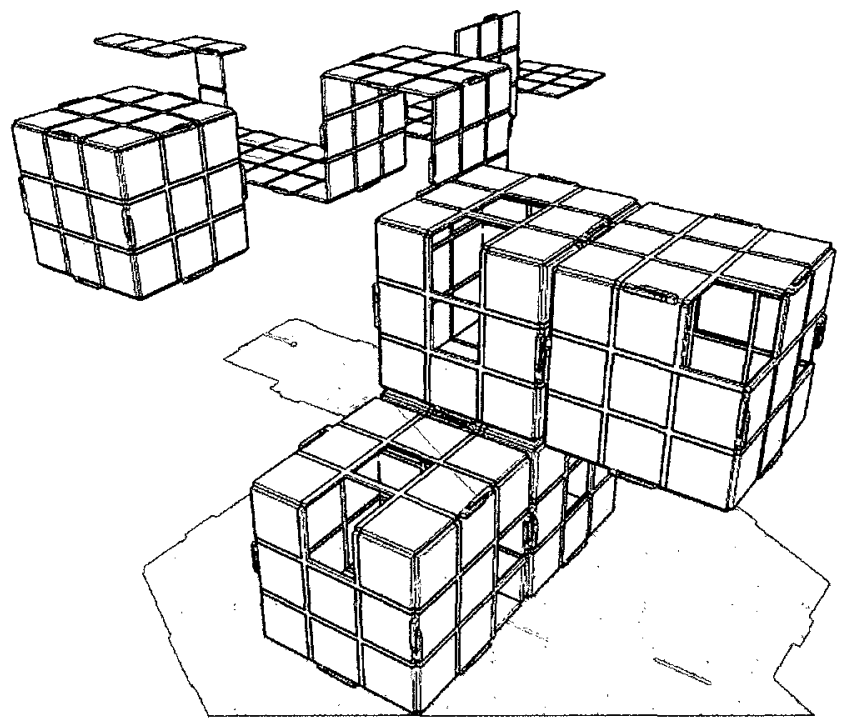

Illustration 24: Kit of parts designed to initialize the collaborative process at Wiki Architecture, 1 of 5

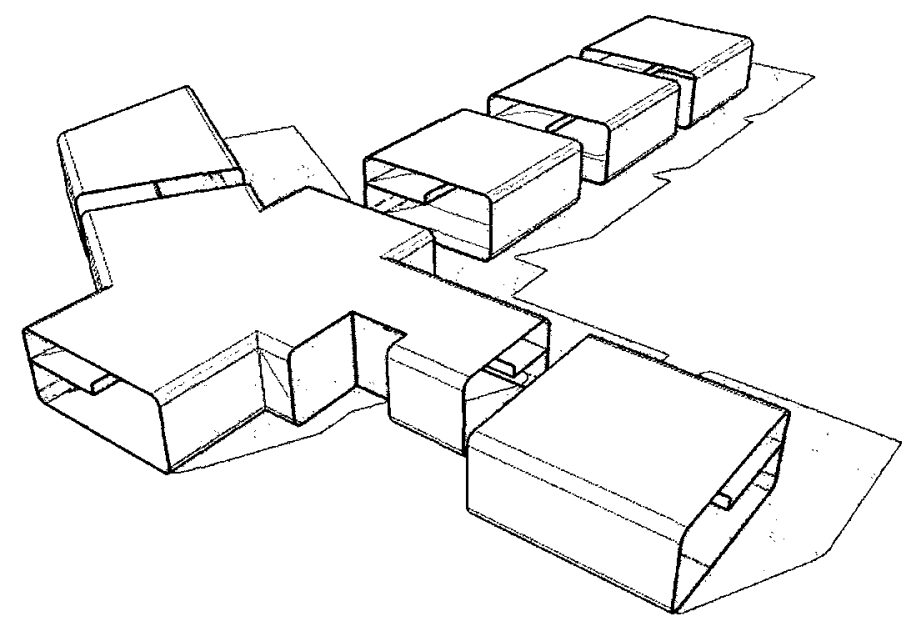

Illustration 25: Initial kit of parts, 2 of 5

Wiki Architecture $\bullet 90$ 


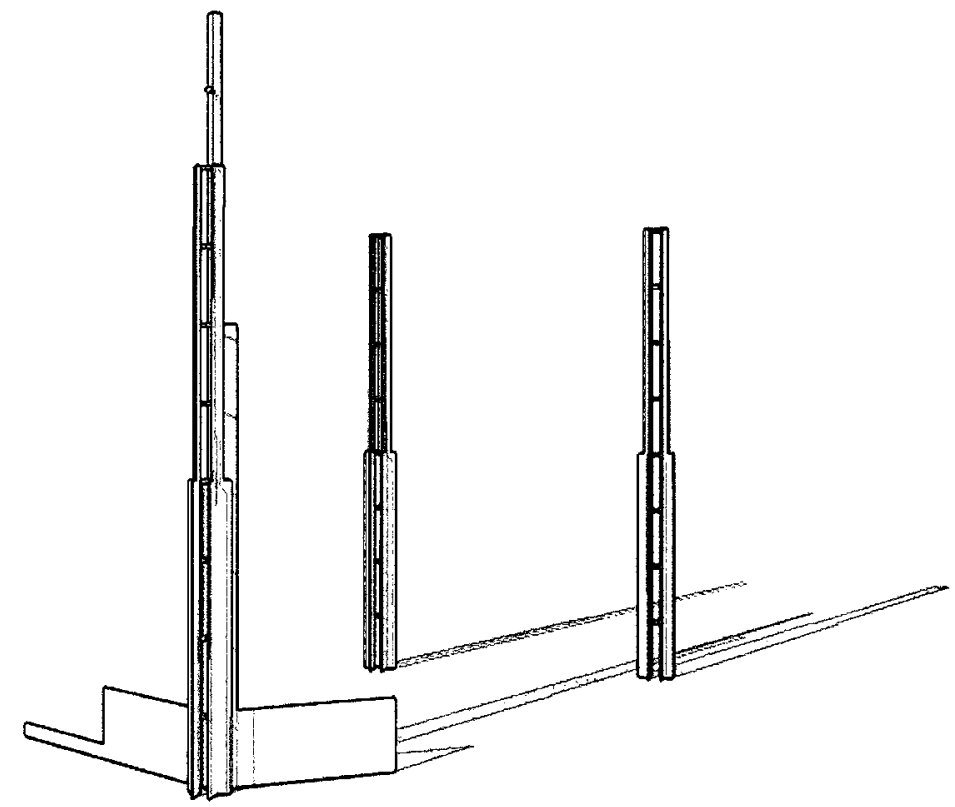

Illustration 26: Initial kit of parts, 3 of 5

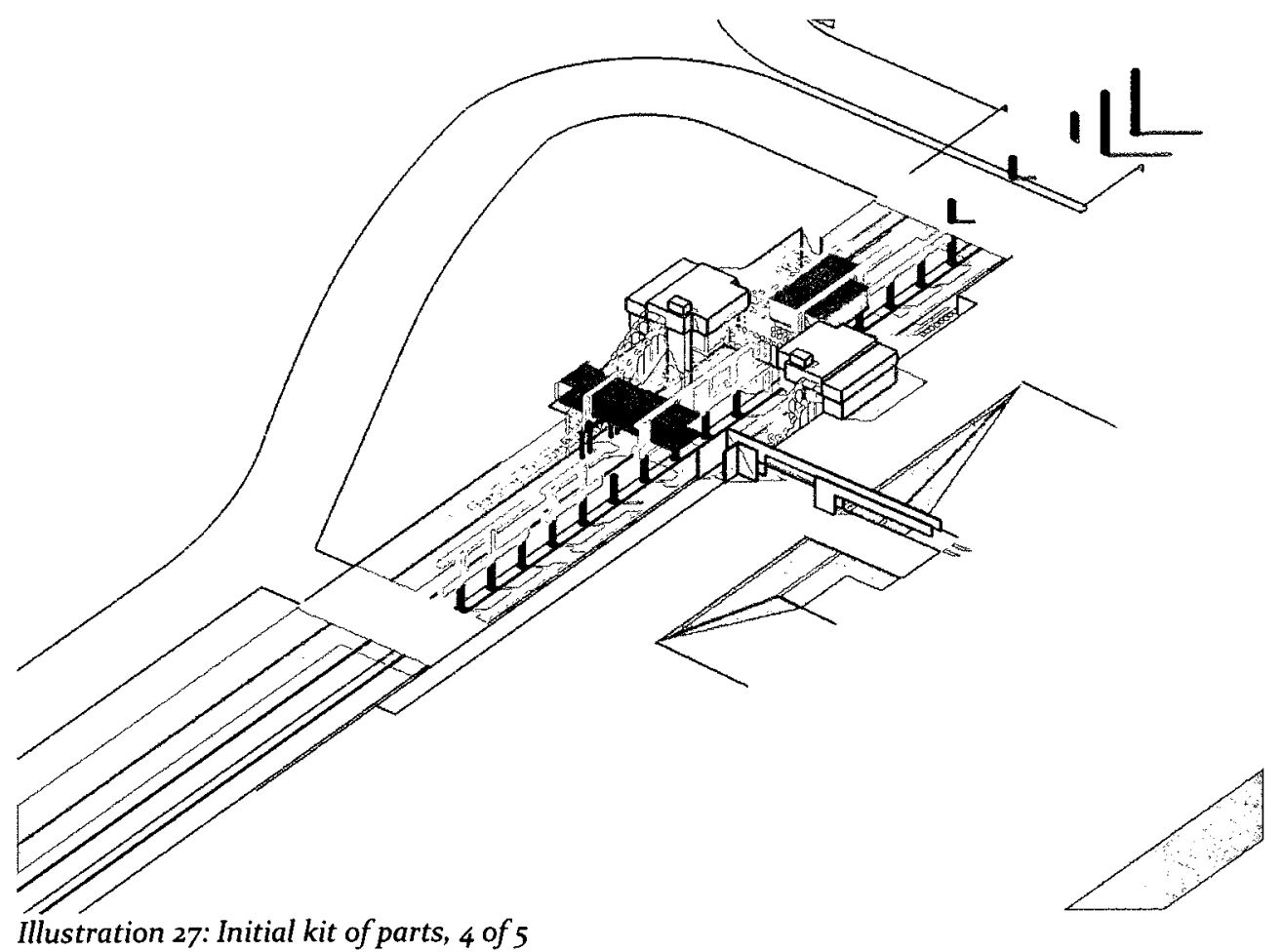

Wiki Architecture • 91 


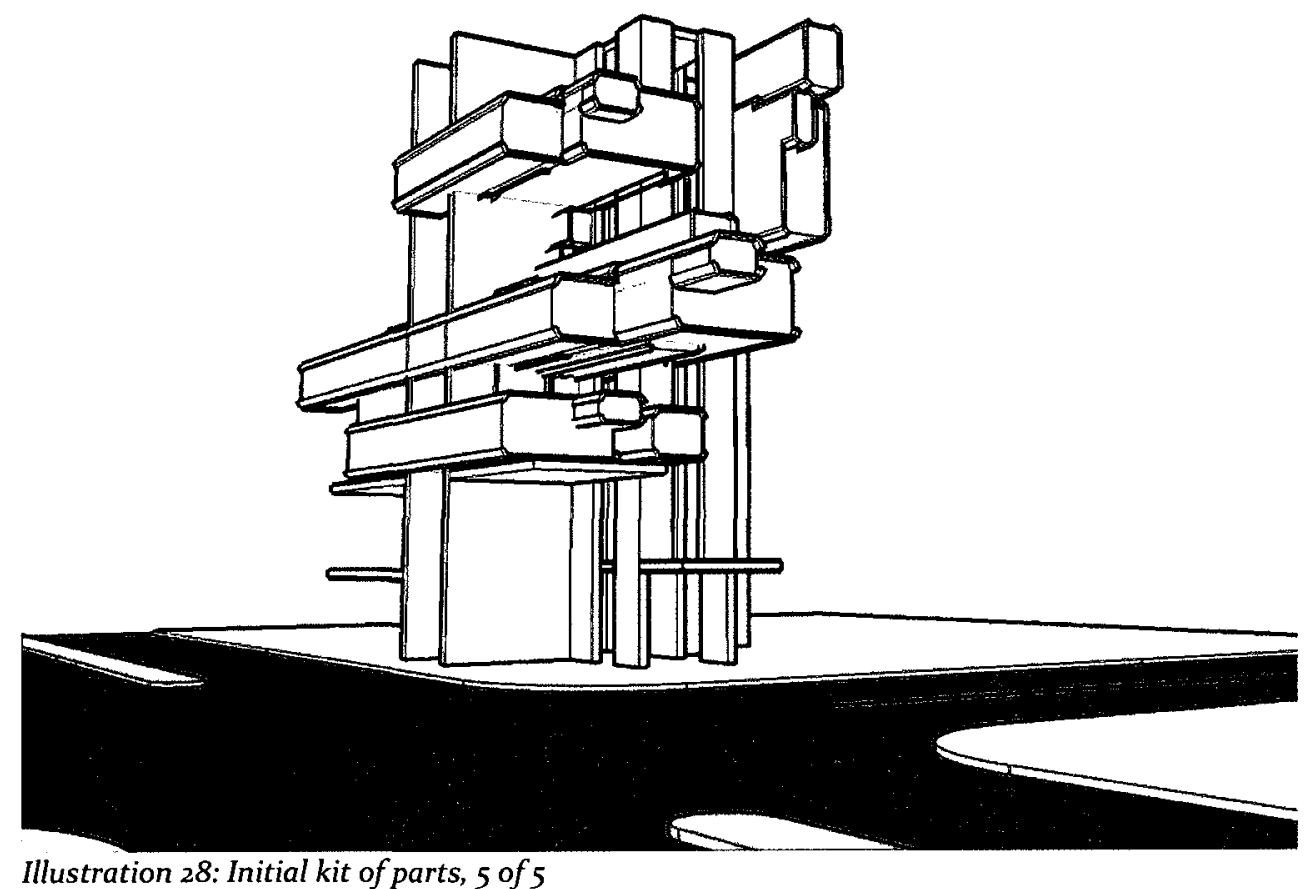

Wiki Architecture • 92 


\section{2.a) Concept}

Below is the concept note that was hosted on Wiki Architecture to familiarized the members with my personal approach:

This White House Redux submission is part of an exploration of the open source phenomenon and ways in which it could inform today's architectural practice.

The White House is an ideal site for this ongoing investigation, because the values attributed to it walk hand-in-hand with the principles cherished by the open source movement. The iconic character of the White House for the American democracy and the ideals embodied by it can be best expressed by the open source model. This is achieved in two main ways: constructive and programmatic.

The open source model has a constructive and generative function. This project is based on a free-for-all scheme sustained by the web-site, where everyone can collaborate, borrow, and contribute regardless of the occupation and abilities. In addition, source of all information about the building, such as plans and drawings, is always available for review and alteration. Therefore, it creates an opportunity for equal participation in and greater transparency of design process.

The open-source is also the building's major programmatic function since the edifice consists of circulational and structural parts which hold detachable units. These units could be redesigned, repositioned and altered at any time using the available source code, which consists of architectural drawings. The building includes other open source inspired program amongst which are information walls, modernized version of speaker boxes and archive of government issued documents. Such facilities are created with the purpose of informing citizens and giving them the opportunity to be more involved with state's affairs.

\section{2.b> Design Process}

The design process of the personal submission was also made transparent, exhibiting conceptual sketches and speculative thoughts. For instance:

Below is a set of sketches depicting what may be described as a anatomically/schematically open source architecture. First five images are open structures that can receive many various dwelling and workplace modules [Illustration 22 through 26]. The structural spires may hold leach-like symbiotic dwelling containers[Illustration 24] along their sides. The diagram image[Illustration 27] that I (archik) made earlier, describes the inner-working of a possible Open Source architecture School. The last two images are another exercise showing the growth progression of a proposed Open Source mall to be located on the current Tunny's Pasture site, in Ottawa[Illustration 28 and 29]. 

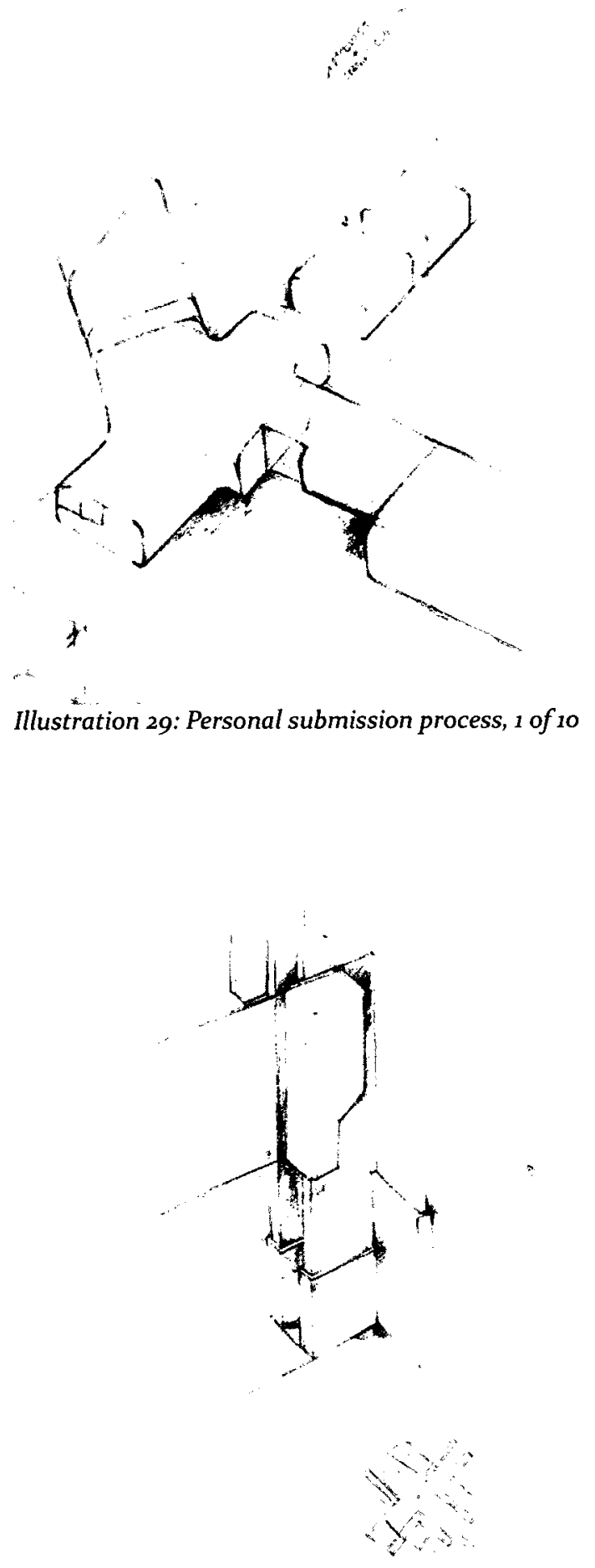

Illustration 30: Personal submission process, 2 of 10 

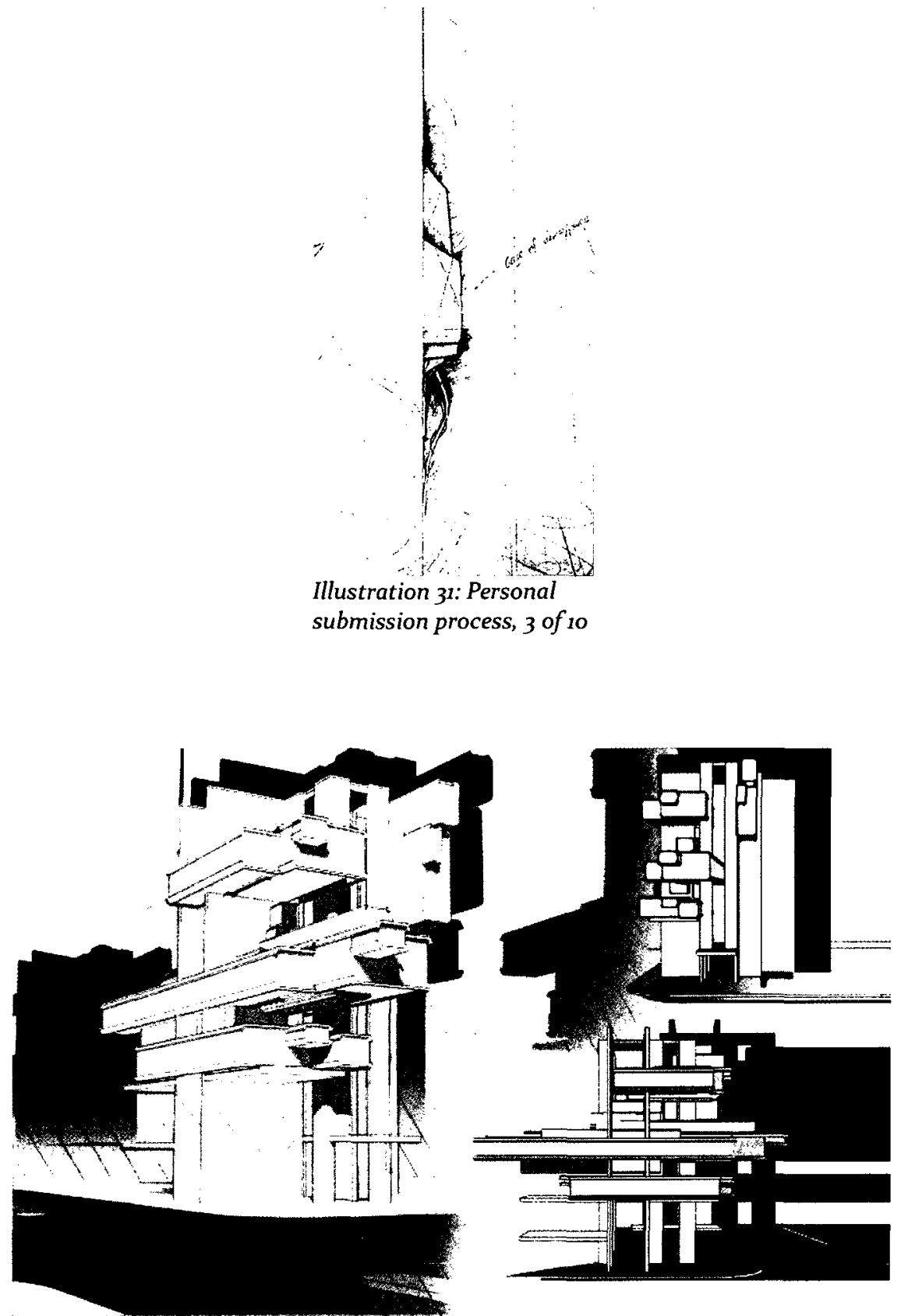

Illustration 32: Personal submission process, 4 of 10 


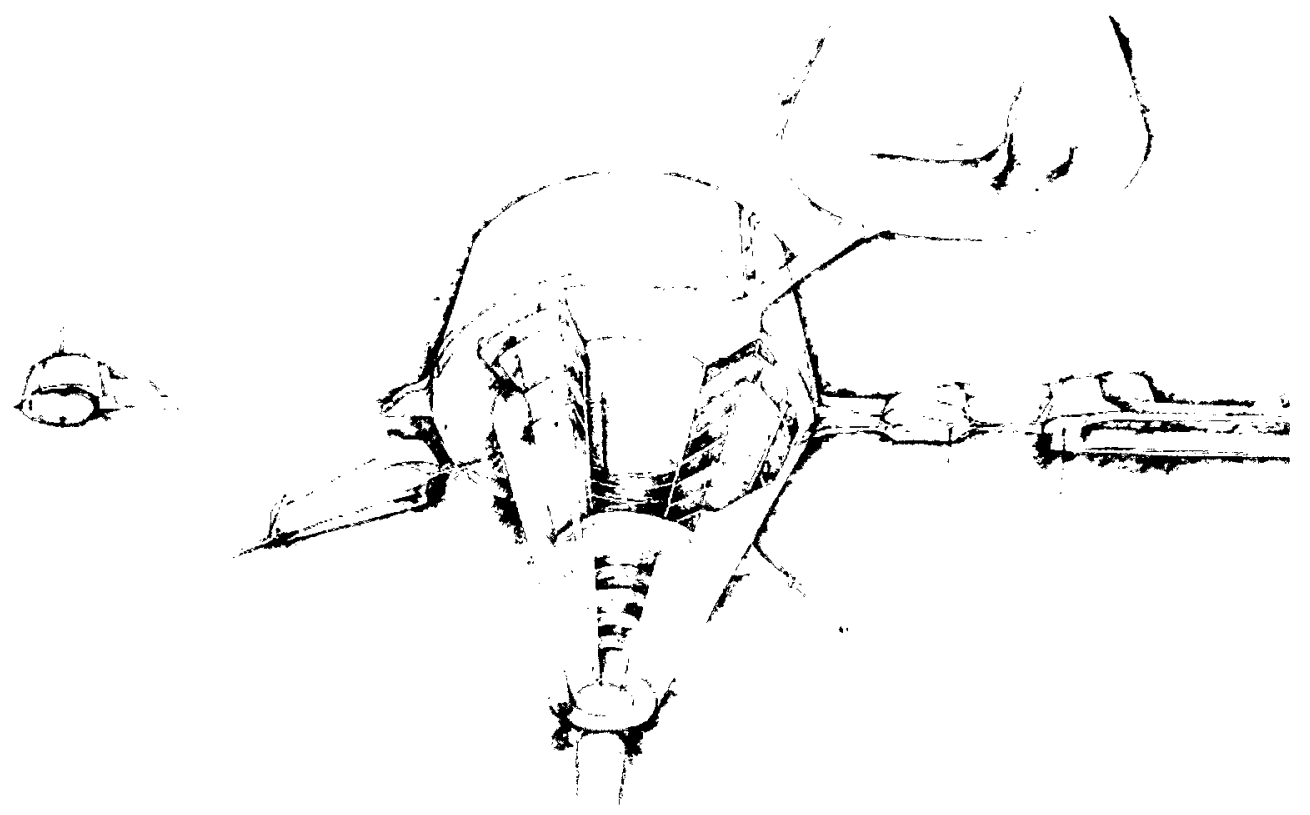

Illustration 33: Personal submission process, 5 of 10

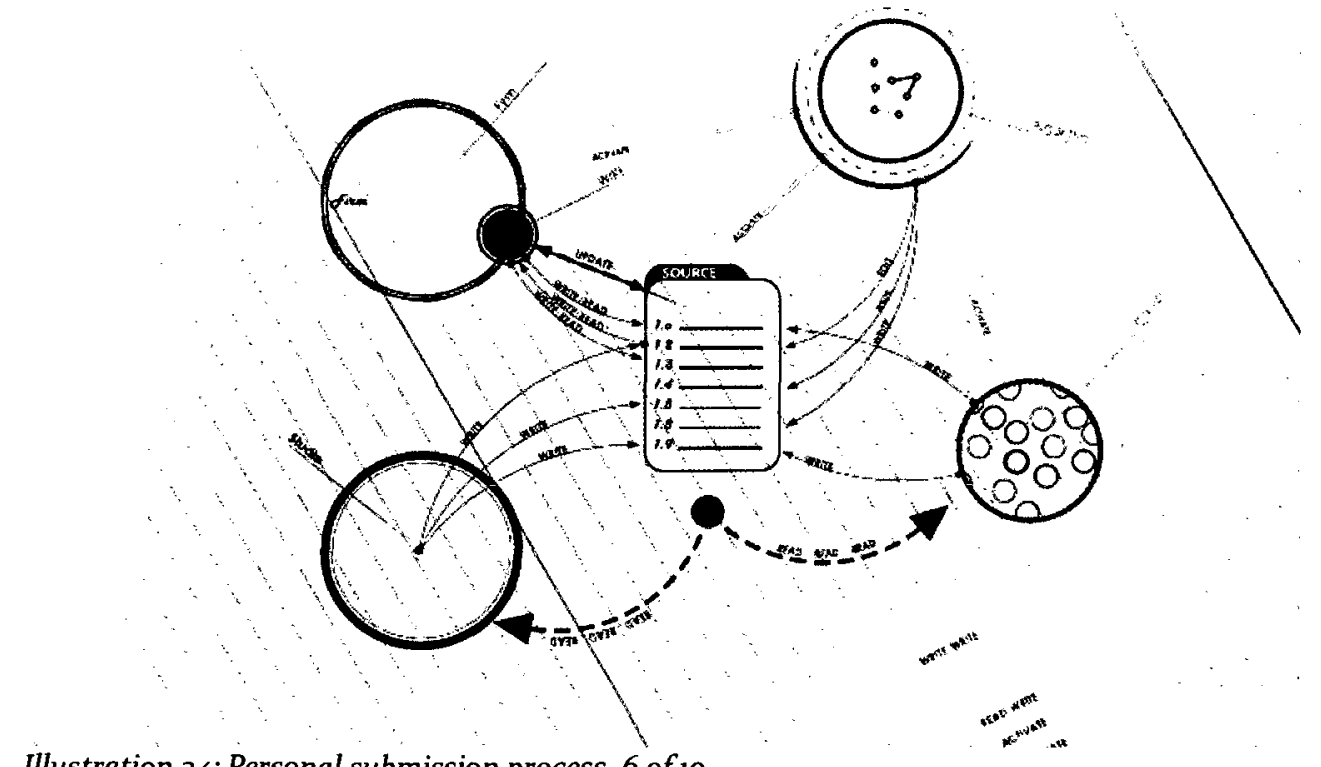

Illustration 34: Personal submission process, 6 of 10

Wiki Architecture $\bullet 96$ 


$$
y^{2}
$$


Another set of sketches portraying a possible tower complex with retractable containers-spaces [Illustration 3o], followed by a tensile structure for the tower[right of Illustration 31], and a sketch of a highway-like garden[left Illustration 31], schematically depicting a lattice network situation, or if you will, can be interpreted as a stitching between the democratic and republican. 


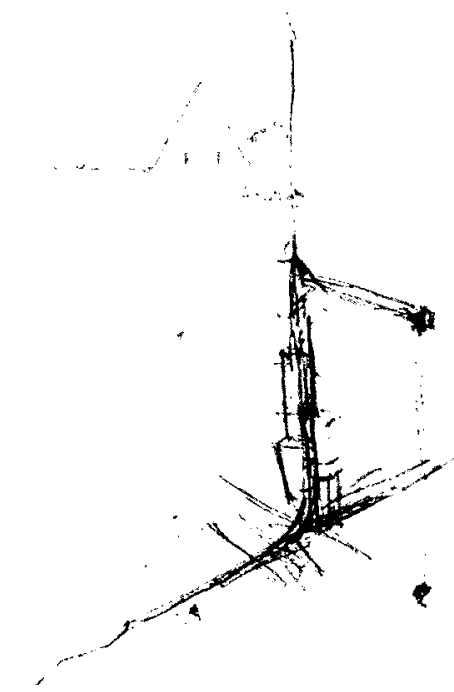

Illustration 37: Personal submission process, 9 of 10

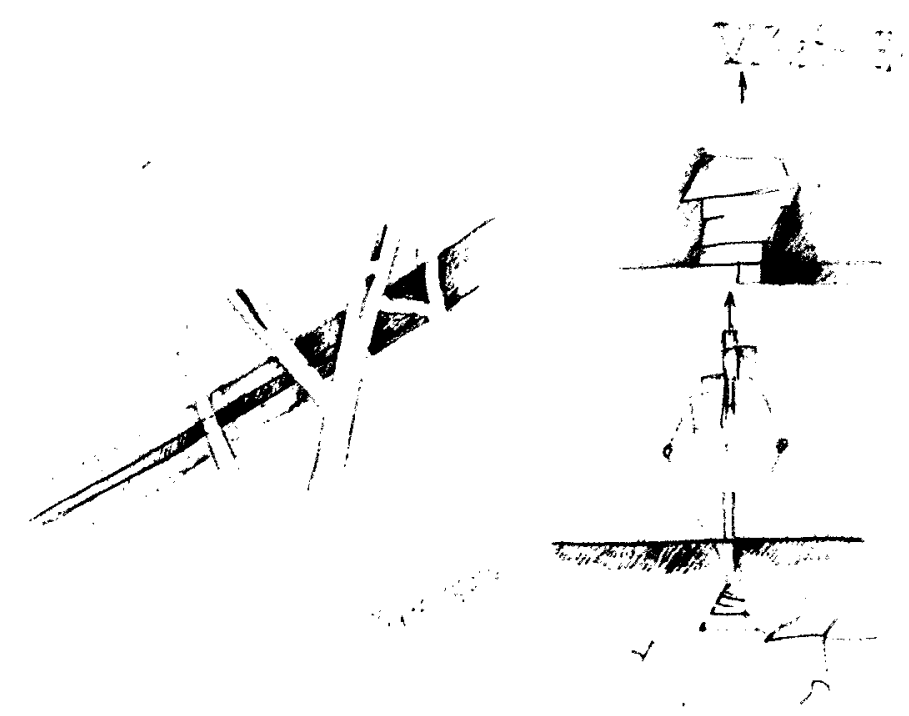

Illustration 38: Personal submission process, 10 of 10 


\section{2.c> Deliverables}

The following are a collection of six panels that became the deliverables of the submission to the competition. The first panel familiarizes the jury with the concept of the design in a popular fashion. 
238 words

The open-source development model captures all aspects of today's software engineering. While neglecting economic tensions, it offers creative freedoms, collaboration and extensive information resources.

- Files

$\therefore$ Add

$\therefore$ Edit

We believe that a democratic state should act alike by offering maximum accessibility, openness of source, and transparency of actions. We also believe in strong collaborative and philanthropic initiatives of empowered public. This public is approaching a cognitive surplus that is due to generation's shifting interests, from the TV, to internet, into wiki. Imagine the effects of such collaborative efforts.

We have appropriated the open-source model in this project to act conceptual, programmatic and representational levels.

\section{http:liarch1k.wikidot.comi}

This wiki web site was established, where all information on the building is made available to general public. Everyone can contribute ideas, review and modify the design at any stage. The building is mainly composed of circulation and structural parts holding detachable units. These units can be altered, redesigned and repositioned per presidential term in discourse with the public using accessible source code material. Also, this structure accommodates a number of open source inspired facilities, such as archives, information walls, speaker's corners, and assembly facilities.

We believe that in the development and working stages, this project will express the cherished democratic principles and values the White House must epitomize. Most importantly, it will reinvigorate public involvement in the state affairs due to the transparency of its functions and the design processes, while providing an extensive information resource

\section{Comments}

\section{Qeseriptign}

Illustration 39: White House Redux - Personal Submission, No. 1 of 6 - Accompanying Text 


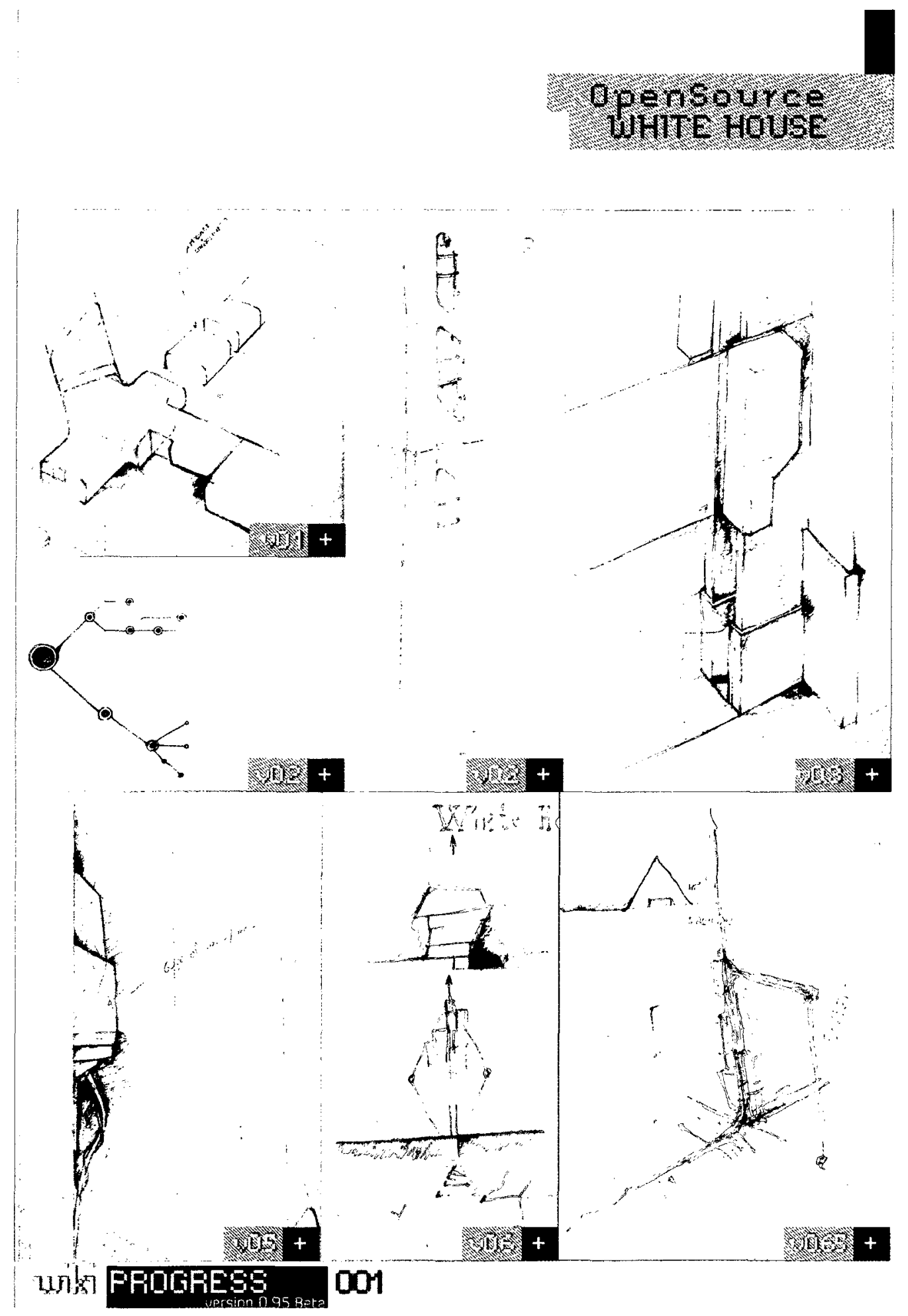

Illustration 40: White House Redux - Personal Submission, No. 2 of 6 - Design Process

Wiki Architecture 102 


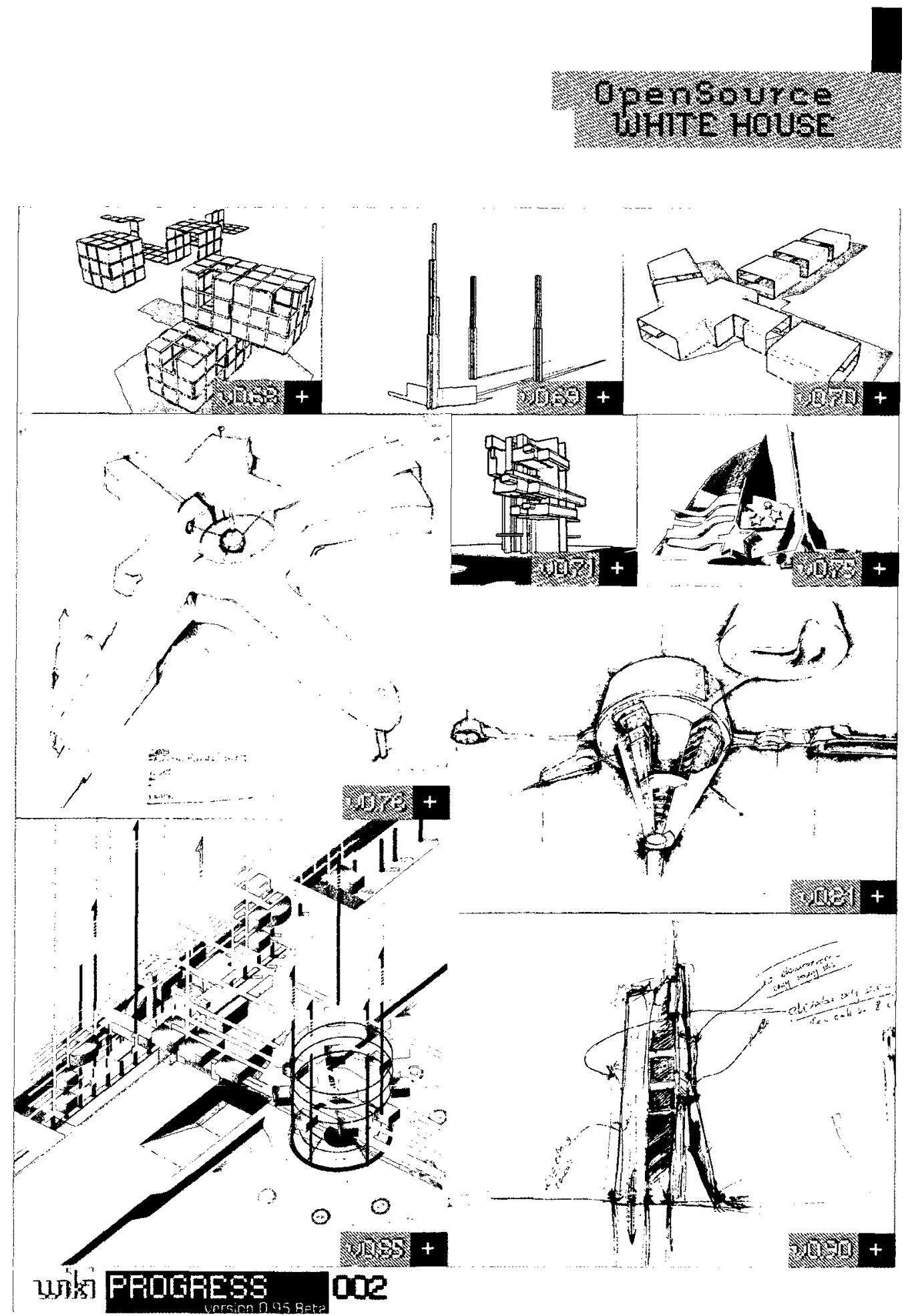

Illustration 41: White House Redux - Personal Submission, No. 3 of 6 - Design Process 


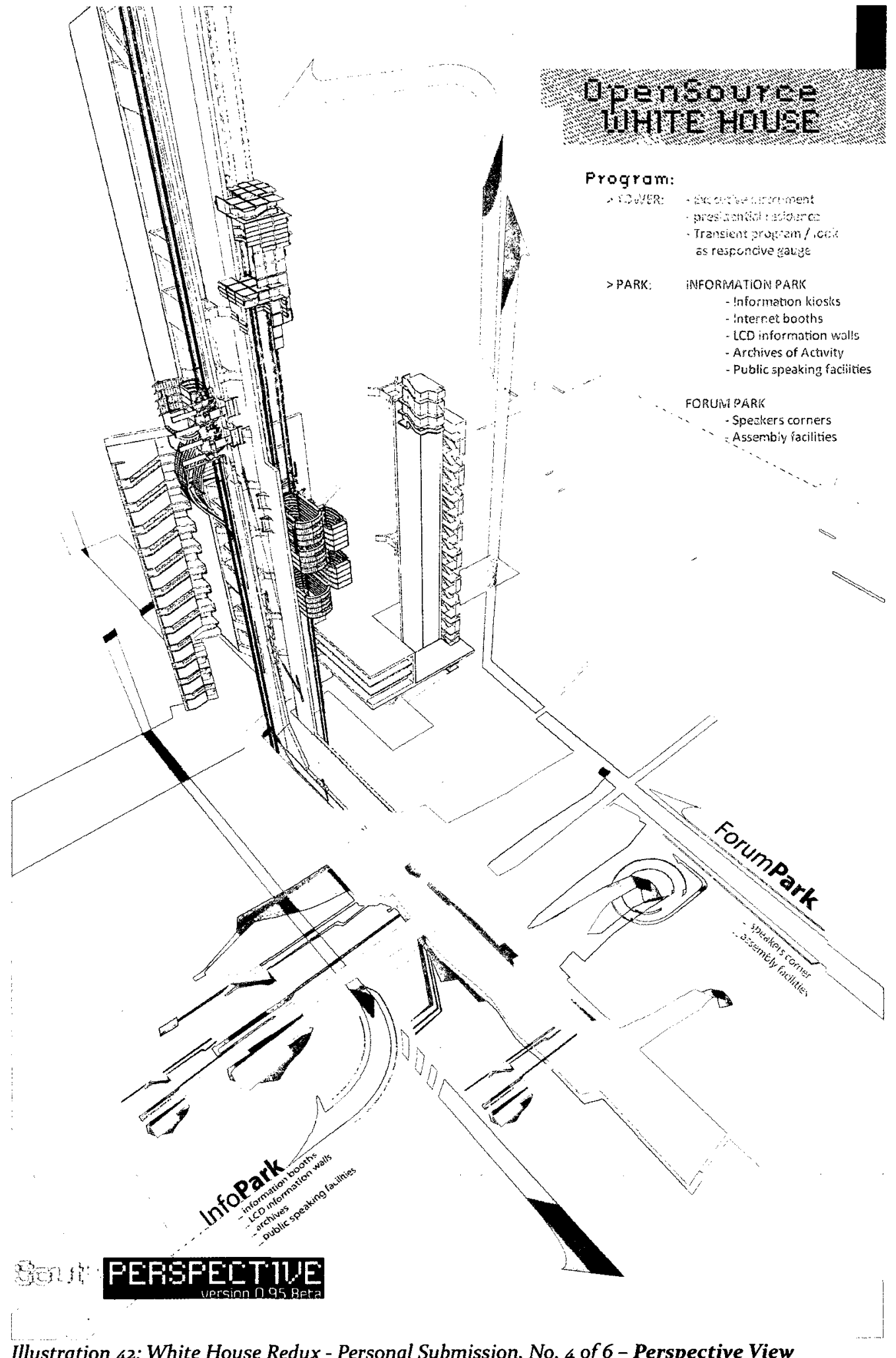

Illustration 42: White House Redux - Personal Submission, No. 4 of 6 - Perspective View 


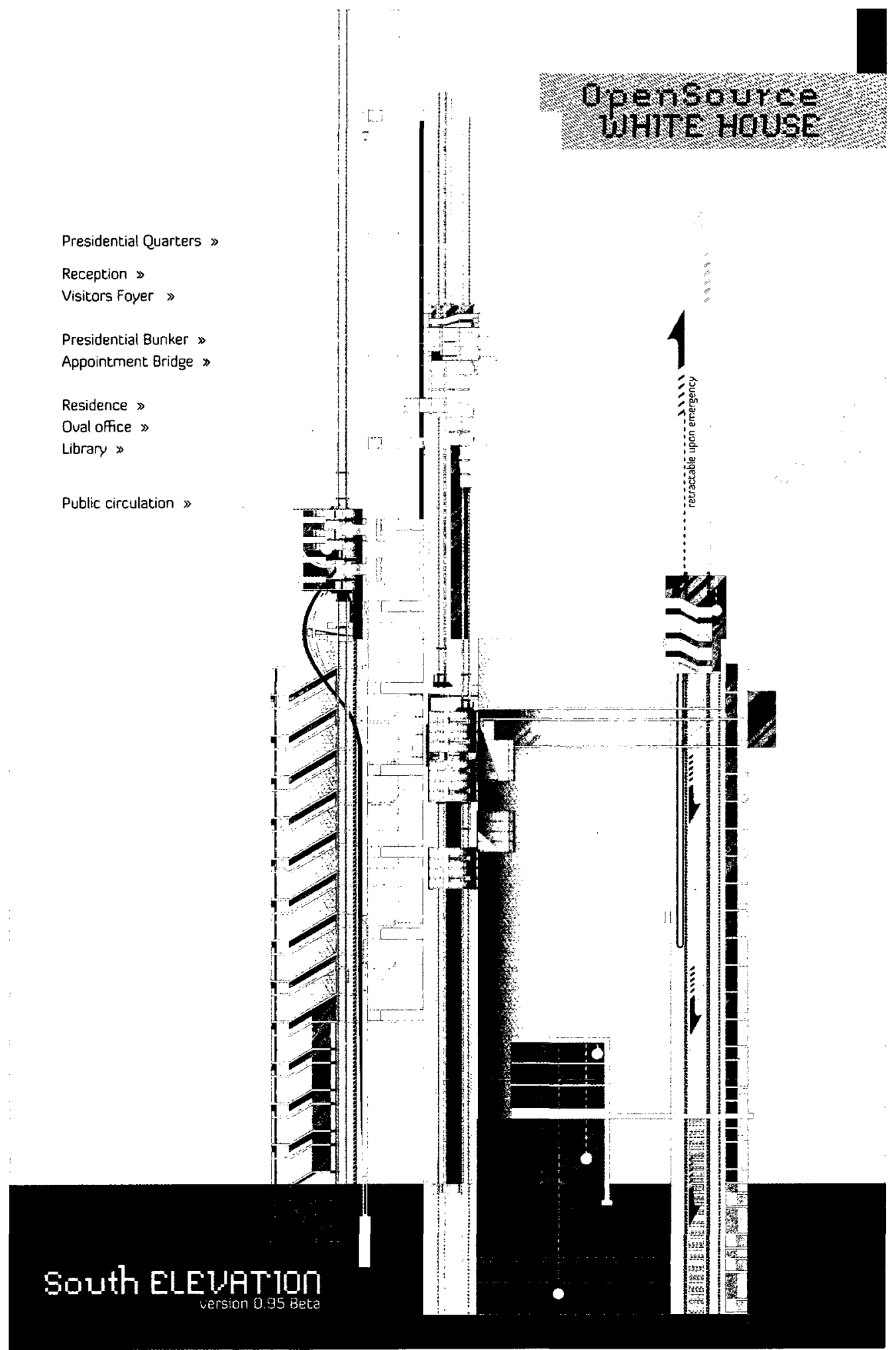

Illustration 43: White House Redux - Personal Submission, No. 5 of 6 - South/Front Elevation 


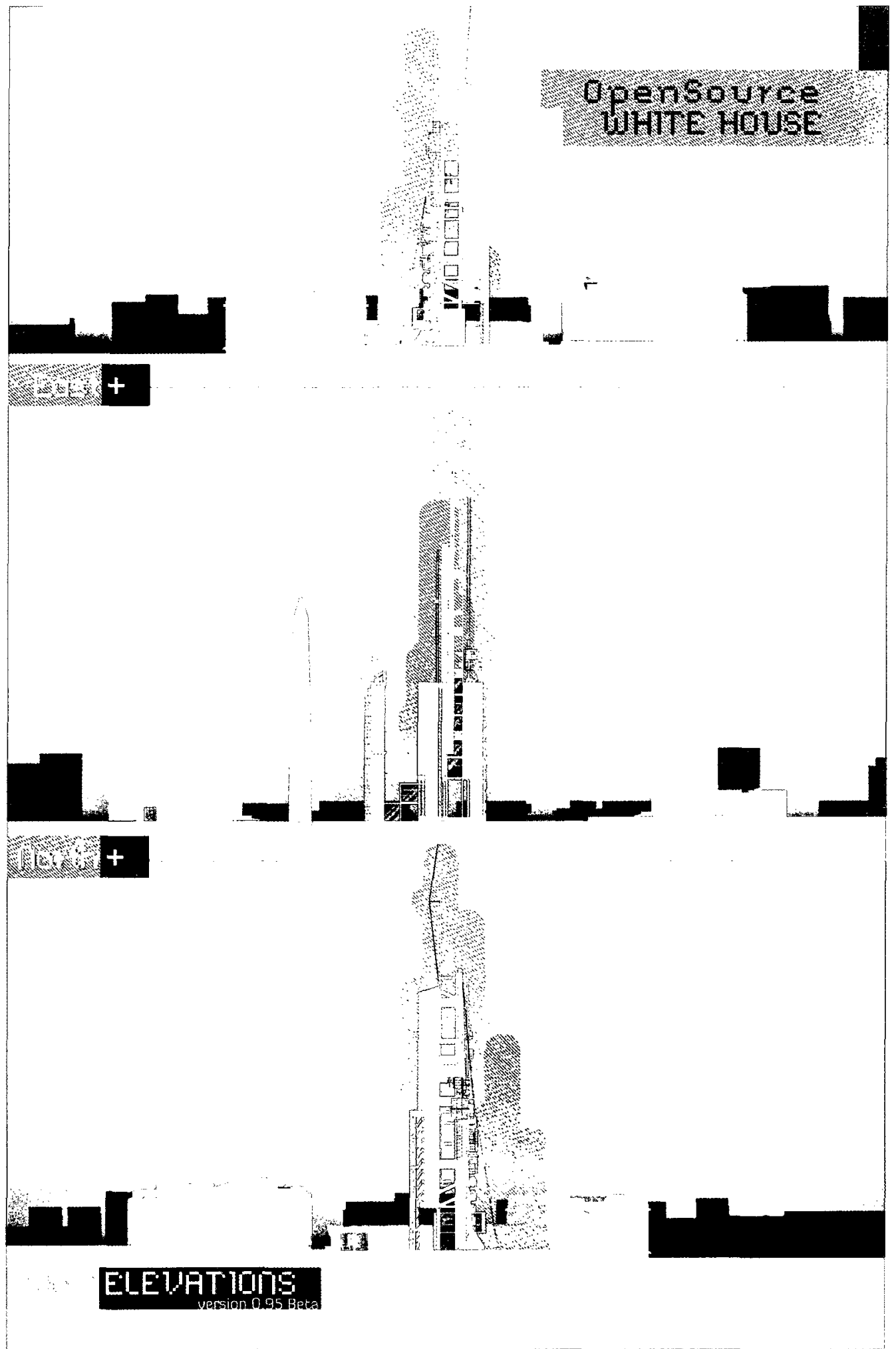

Illustration 44: White House Redux - Personal Submission, No. 6 of 6 - East, North, West Elevartions 


\section{3) Glimpse at the output of collaborative work in progress}

All the preceding section in this paper deal with the open source as an instrument. They describe the context, philosophy, technology, alternate applications, architectural relevance, and the nominal state of the wiki software in use. Once Wiki Architecture was established as a conduit of the collaborative design on the Internet, my autocratic capacity to control the project was given up and instead I became one of the contributors. I had equal freedom to alter the design hosted on the wiki and a privilege to encapsulate the collaborative process by publishing it.

In this section we are to look at the product of the collaborative work as it is facilitated by Wiki Architecture. Since the wiki remains active examples exhibited below are only a snapshot of the work that accumulated by May 3, 2009.

\section{婂}

Below are examples of submissions that were made to Wiki Architecture by its members in a chronological order. First two digital models were generated prior to the White House Redux deadline, and hence, provided conceptual and formal inspiration for my personal submission to the competition. Traces of these designs may be evident in the panels especially the windmill module, which initially informed the curiosity in a tower solution. 


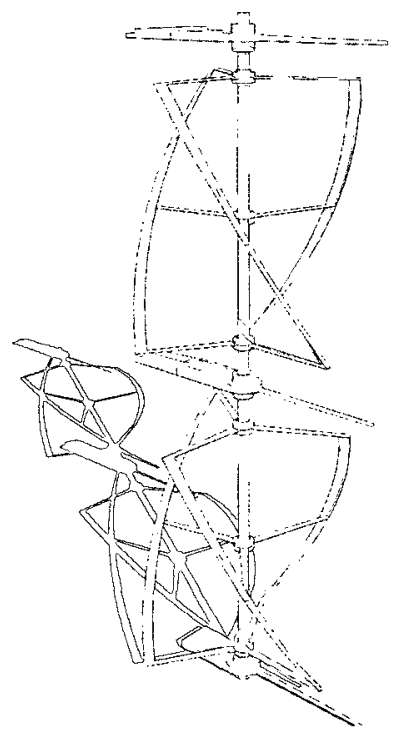

Illustration 45: First addition to the kit-of-parts library, made by the wiki user "smantzer"
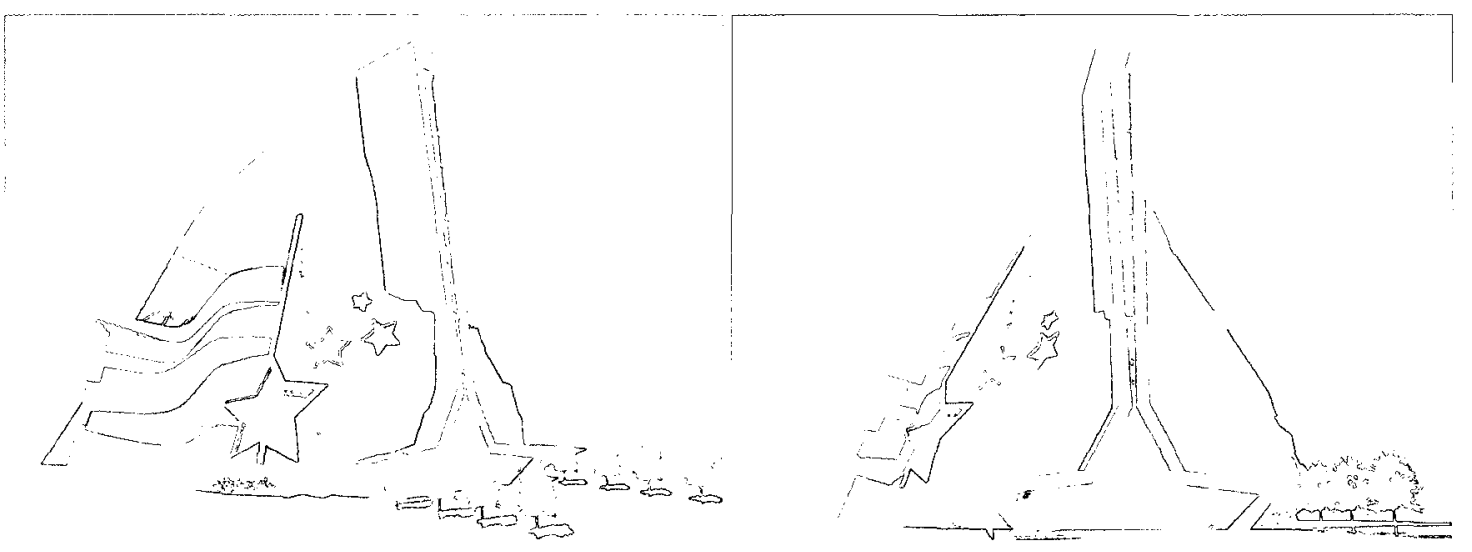

Illustration 46: Concept by the user "smantzer", 1 of 4 Illustration 47: Concept by the user "smantzer", 2 of 4

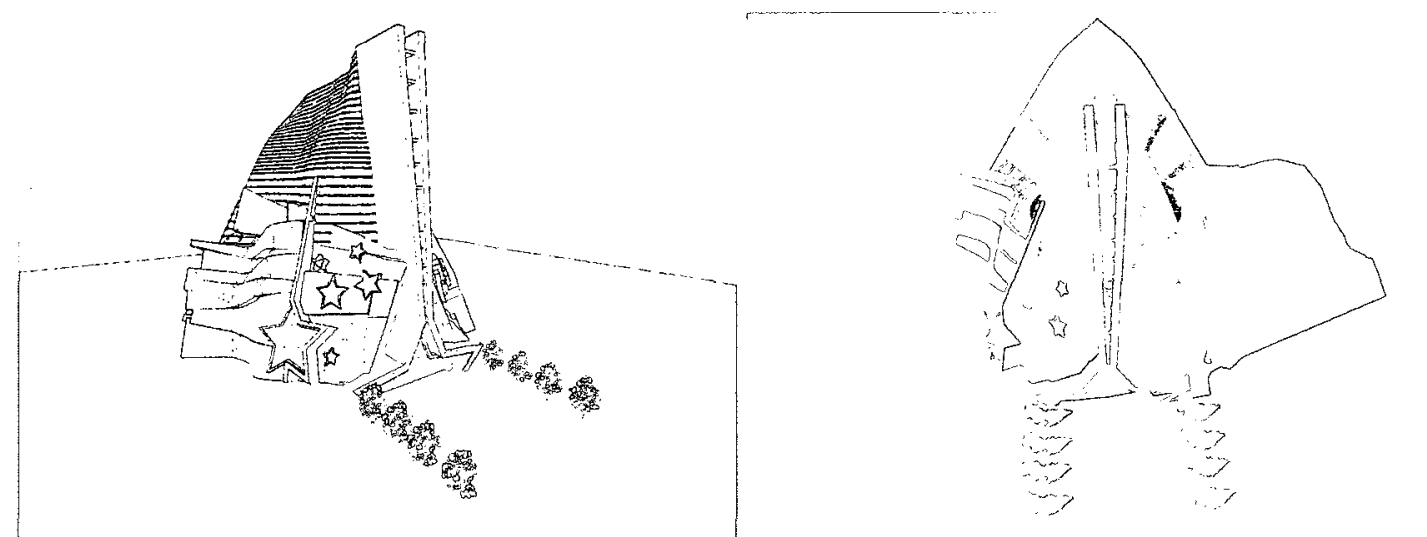

Illustration 48 : Concept by the user "smantzer", 3 of \& Illustration 49 : Concept by the user "smantzer", 4 of \& 
The following is the most current reincarnation of the White House design as it was generated by the user "Slychimera". In his own words:

"Developing archık's model a further layer of concept was added. The evolution through open source is mediated with a historical time line. The development now occurs horizontally and the building undergoes an 'expansion' whenever the country has reached an achievement in civil progress. The building organizes itself and its evolution through the plaza and main circulation. A $3 \mathrm{D}$ model and text will follow." 


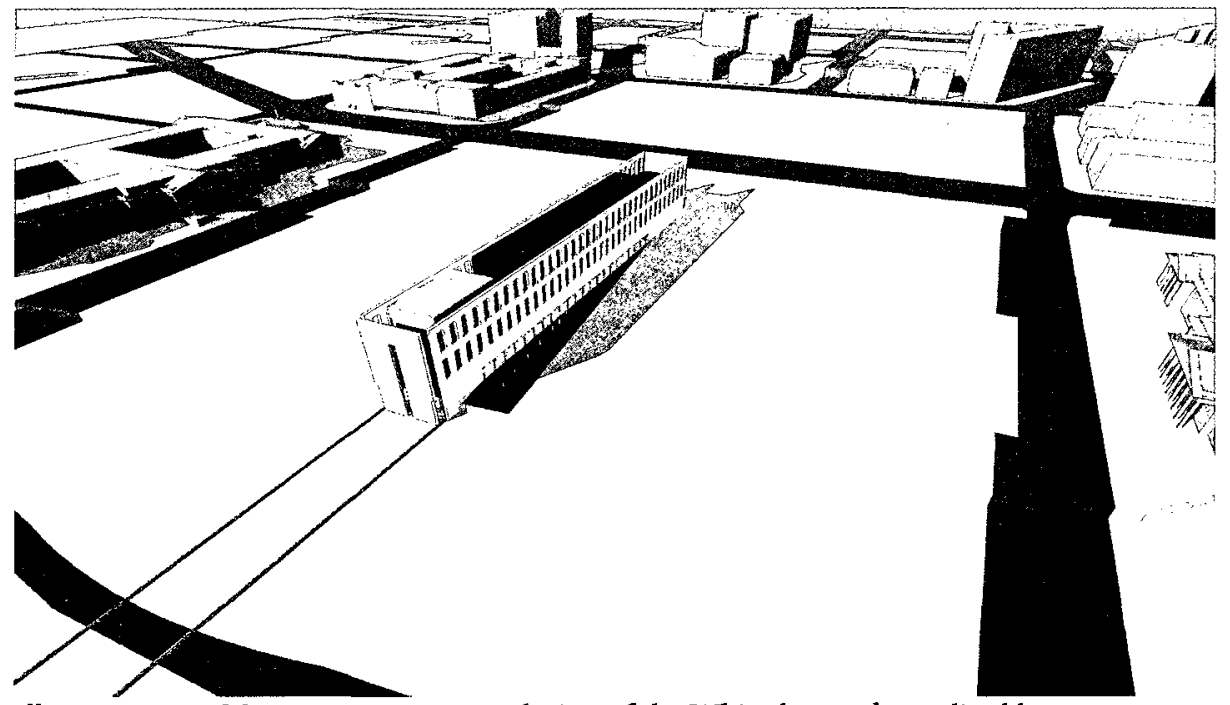

Illustration 50: Most current concept design of the White house, last edited by "Slychimera", 1 of 2 

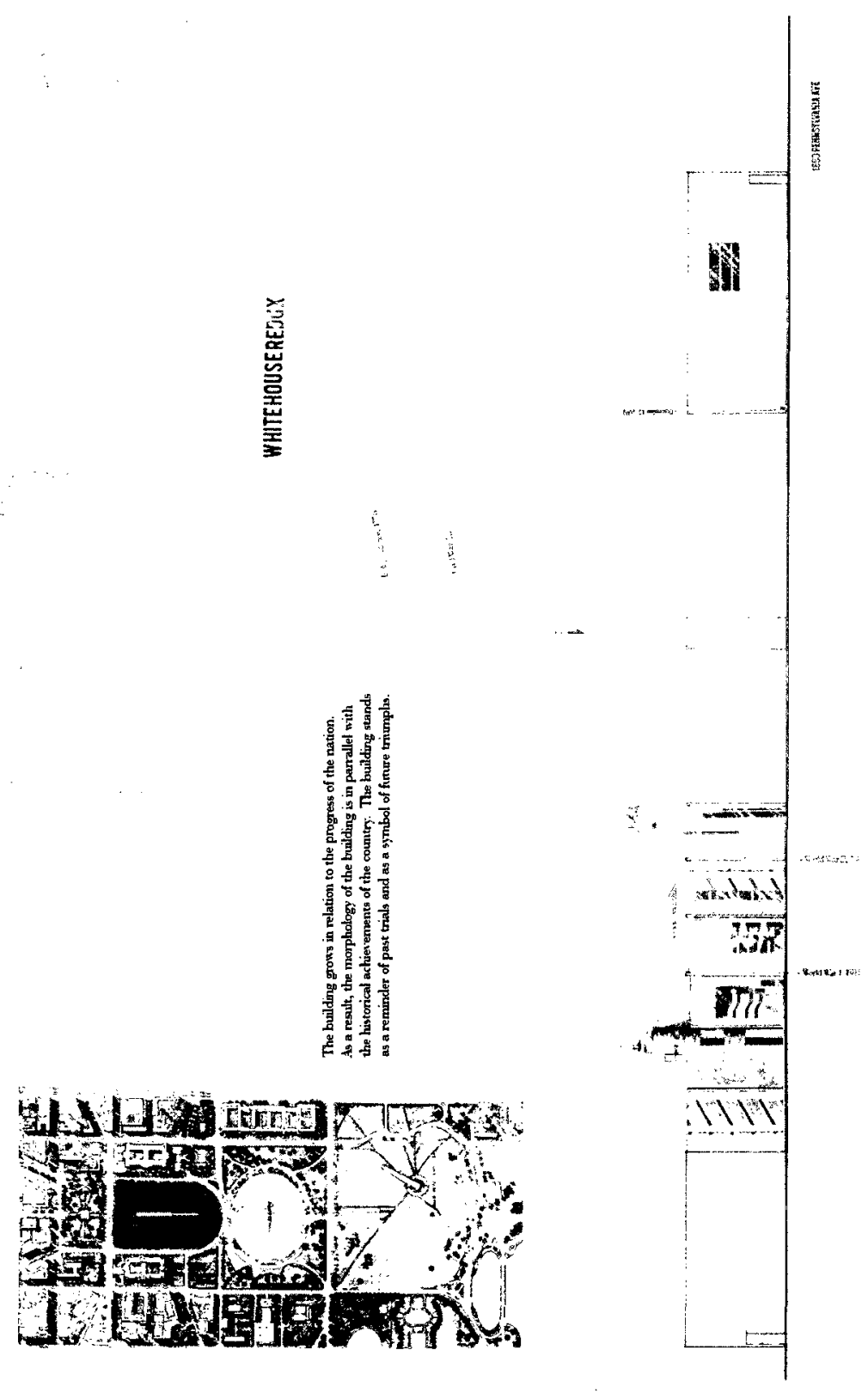

Illustration 5: Most current concept design of the White house, last edited by "Slychimera", 2 of 2 


\section{$10 »$ Conclusion}

When approaching this project a commitment was made to conduct the research and experimentation most objectively in order to let the results demonstrate whether the open source mode of software development may be advantageous if applied to the creative architectural environment.

To begin, the project looked at the historical evolution of the authorship paradigm, both in theory and in reference to the realms of literature, semantics, craftsmanship, and, most importantly, architecture. As one learned, this paradigm was known to fluctuate between the extremities of viewing the author as an ultimate creator and owner of their work, and a figure that accepts creativity as merely a process of intertextualization. We saw that throughout the modern architectural discourse a number of practices were set to challenge these notions, to a degree where even the inhabitant was incorporated in the creative process. Since open source welcomes a similarly promiscuous protocol of handling and sharing information, the idea of marrying both open source and architecture proved to be rather congruent.

In view of these similarities an experiment was established in the virtual environment of the Internet Web, where the source of the architectural project White House Redux - including parallel projections, computer models, imagery, and conceptual material - was freely editable, and the process of this collaboration was made transparent. This was achieved with the help of a dedicated wiki Web page - a technology that is most common in the practice of open source software development. In the process, the wiki was heavily refashioned to adapt to the specificities of working with architectural "source" material rather than the usual software code. 
Today, twelve months after the conception of Wiki Architecture, the project is only at its early stages of maturity, however, some of the results are already noteworthy. So far the wiki page was visited 5269 times by miscellaneous traffic and remains consistently active (see Illustration 52 ). Only in the past month $3.7 \%$ of these visits were longer than an hour, and $2.6 \%$ of visitors returned to the page over five times. Visitants were from across fifty four countries, and in $90 \%$ of the cases gravitated from within the immediate wiki network community. Wiki Architecture was awarded the "Wiki of the week" status buy Wikidot.com for the period of five consecutive weeks. There are eighteen members who read, contribute, and comment on the content. Some of these seek for ways to collaborate further using the Wiki Architecture environment. Finally, nine articles of various backgrounds were published on the Internet describing the wiki, while over $60 \%$ of the daily traffic exploits the Web page as a content resource - browsing and downloading the data for personal use.

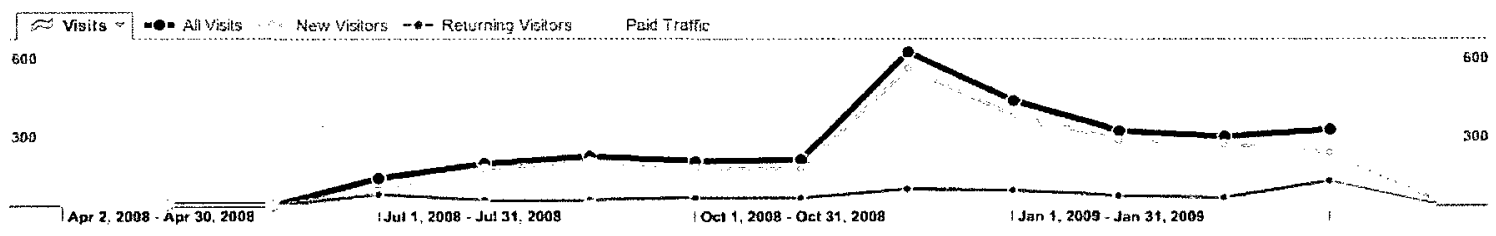

Illustration 52: Wiki Architecture visitors overview, from April 2nd, 2008 to May 3 rd, 2009

Source: Google Analitics. https://www.google.com/analytics (accessed May $4^{\text {th }}$, 2009) 
This statistical information renders the experiment as successful in its ability to engage an active community. This is most notable taking into account the project's intangible nature, and very little to offer back to the involved individuals.

However, in addition to the successes related to popular acclaim, some practical challenges became evident as the project went along. One of the central difficulties encountered, when attempting an architectural collaboration over the Internet, is the management of the two and three dimensional data. With the advent of the web $2.0^{148}$ many new tools were introduced that allowed sharing of auditory, textual, and image information. In some cases efforts have been made to facilitate less than complex volumetric data. However, none of these attempts have ever made it accessible enough for the end user to freely alter flat drawings or three dimensional models within the immediacy of an Internet browser window.

Like many marketed trends, in addition to expanding the exposure it is also important for a product to posses the ability to be sampled and tampered with. That is the reason behind trial periods offered in the Internet services and computer applications. Open source programs are free to try an use, yet, in the professional setting they also require a training period in order to be fully appreciated. An architectural wiki may offer a portal into a shared design but it appears to appeal only to a small group of Internet enthusiasts. Ultimately, this may not necessary be a sign that amalgamation of open source and architecture is obsolete. On the contrary, it may connote that a different skill-set will soon be welcomed in the future of architectural practice.

The most crucial obstacle of this research became the ability to define and communicate exactly what aspect of architectural work may successfully become open sourced. Throughout the experiment this question was left open-ended in order to welcome a multitude of different

148 N.B. Web 2.o, as coined by Dale Dougherty and Craig Cline at the O'Reilly Media Web 2.0 conference in 2004, is the second generation of the World Wide Web in which content is user-generated and dynamic, and software is offered that mimics desktop programs - WEB 2.o. Dictionary.com. Webster's New Millennium ${ }^{\mathrm{TM}}$ Dictionary of English, Preview Edition ( $v$ 0.9.7). Dictionary.com, LLC. http://dictionary.reference.com/browse/WEB 2.o (accessed: May 04, 2009). 
inputs and hopefully arrive at a solution through evolution. However, the involved parties consistently queried regarding this matter. It became clear that the margin of tangibility between the open source and architecture is both the key for prominent adaptation as well as an opportunity for creative solutions.

Should the collaboration remain only a theoretical and formal exercise, residing strictly within the virtual realm, its purpose would be only in academic training. Immediately, this would catalyse an influx of questions pertaining to the capacity of such system to educate, as well as, the validity of virtual creations when transposed into the built environment. Decidedly, in this case open sourced architecture would serve as an extensive resource for inspiration.

Using the open source methodology though the design phase is a more tangible approach. It is, in fact, the way in which members of Architecture for Humanity have collaborated since 1999, targeting housing crises around the globe. This approach is unmatched in its capacity to generate professional knowledge, helping the learning process and eliminating the effects of seniority in architectural profession.

Today's tendency towards the propitiatory Building Information Modelling (BIM) technologies supports the conspicuous need in a unifying medium where the rapidly growing architectural knowledge could be accessed on demand. It is natural to assume than that theory and history should become part of such environment - expanding on the reasons and causes behind the techniques and technologies employed.

However, while the built results of open sourced architecture would open another door in architectural theory, crystallizing of such a dynamic process at any point raises ethical concerns: At what point is such a process complete? Who is in charge of these decisions, and who manages the building process?

According to Cedric Price the inhabitants have an impact on architecture that is only matched by that of the architects themselves. Many architects work towards this ideology creating architecture that is more modular and containing more moving parts - empowering the 
inhabitants to have an even more direct command over their environment. Alternately, as we learn from the accounts of such historic cities as Rome, Berlin, or Jerusalem, the constant reinterpretation, rebuilding, reuse, and reconstruction of buildings though the ages is in fact the most explicit form in which architecture manifests its open sourced nature. Consequently, architecture may viewed as open throughout, and addressing the design process only completes this ubiquitous cycle.

Lastly, while open source development remains open to any contribution, it is exposed to the possibility of becoming nonsensical when transposed into the bricks-and-mortar environment. Some solutions may prove unbuildable, unsustainable, or simply uninhabitable. On one hand, in oder to avoid this from happening a smart evaluating mechanism(self-organizing, or powered by an acquired expert base) could be placed to screen from such discrepancies. On the other, as Peter J. Bentley notes, only an unattended evolution of trial-and-error and survival-ofthe-fittest, can produce a solution as complex and intricate as the nature itself. ${ }^{149}$

$$
\text { 采 }
$$

At this stage in the Wiki Architecture experiment the wiki technology is in place. It it is functional and acclaimed well within the Internet community. Some functionally enhancements could be drawn from the experiences gained thus far to make the software more efficient and suitable for the architectural proper. However, to date the duration of the project since the conception is simply insufficient for a fair judgement to be made. The creative transactions that took place within the wiki are few and exhibit bereft maturity to define a complete project, and a more intensive collaboration has yet to occur. Consequently, a clearer stance could not be yet generated regarding the potential of collaborative design in an open source framework.

149 Bentley, J. Peter. "Climbing through Complexity Ceilings", in Network Practices, ed. by Anthony Burke, Therese, Tierney, (New York: Princeton Architectural Press, 2007),178 -195. 
The redesign of the White House has drawn a great deal of interest and responsiveness. One can conclude that open source collaboration would be successful and desirable in an academic environment. However, since the project is only a virtual exploration it is hard to draw any concrete lessons from this exercise hitherto building practice. After all, open source software is as tangible for the end user as the proprietary. Thusly, in order to make a more objective conclusion to whether open source architecture is possible a design-built approach would be desirable. 


\section{1»Bibliography}

1» Canadian Intellectual Property Office. A Guide to Copyrights. Canadian Intellectual Property Office.

http://www.ic.gc.ca/eic/site/cipointernetinternetopicnsf/eng/wr00506.html\#nol (accessed April 16th, 2009).

2» GNU Operation System. "Public domain software." GNU. http://www.gnu.org/philosophy/categories.html\#PublicDomainSoftware (accessed April 15th, 2009).

3» How Stuff Works. "What does open source mean?" How Stuff Works.

http://computer.howstuffworks.com/question435.htm (accessed April 2nd, 2009).

4» One Architecture. “Corporate Avante-Garde.” In Hunch 6/7, by Sigler, Jennifer, Roemer Van Toorn and W M J Arets, eds. Rotterdam: Episode Publishers, 2003.

5» Open Source Initiative. http://www.opensource.org/ (accessed April 15th, 2009).

6» Open Source Initiative. "The Open Source Definition." Open Source Initiative. http:// www.opensource.org/docs/osd (accessed April 15th, 2008).

7» The American Heritage Dictionary of the English Language, 4th edition. Boston: Houghton Mifflin Company, 2007.

8》 "The Homeric Hymns and Homerica. "In Homeric Hymn 20 to Hephaestus, trans. by Hugh G. Evelyn-White. London: Harvard University Press, 1914.

9» WEB 2.0. Dictionary.com. Webster's New Millennium "Dictionary of English, Preview Edition (v 0.9.7). Dictionary.com, LLC. http://dictionary.reference.com/browse/WEB 2.0 (accessed May 04, 2009). 
10» WordNet 3.0 dictionary. Princeton University, 2006. http://wordnet.princeton.edu (accessed March 27th, 2009).

11» Alberti, Leon Battista. "On the Art of Buildung." Ten Books, IX, 10, by Joseph Rykwert, Robert Tavernor and Neil Leach. London: MIT Press, 1988.

12» Alexander, Christopher. The Timeless Way of Building. New York: Oxford University Press, 1979.

13» Anstey, Tim, Grillner, Katja, and Rolf Hughes. Introduction to Architecture and Authorship by Anstey, Tim, Grillner, Katja, and Rolf Hughes, eds., 6-16. London: Black Dog Publishing Limited, 2007.

14» Anstey, Tim. “Architecture and Rhetoric: Persuasion, Context, Action." In Architecture and Authorship by Anstey, Tim, Grillner, Katja, and Rolf Hughes, eds. London: Black Dog Publishing Limited, 2007.

15» Banham, Reyner. A Critic Writes: Selected Essays by Reyner Banham, selected by Mary Banham, Paul Barker, Sutherland Lyall and Cedric Price. Los Angeles: University of California Press, 1997.

16» Barthes, Roland. "The Death of the Author. "In Image, Music, Text, by Roland Barthes (1968). USA: Twenty first printing, 1999.

17» Bennett, Andrew. The Author. London: Routledge, 2005.

18» Bentley, J. Peter. "Climbing through Complexity Ceilings." In Network Practices, by Anthony Burke and Therese, Tierney, eds. New York: Princeton Architectural Press, 2007.

19» Bey, Hakim. "The Temporary Autonomous Zone: Ontological Anarchy, Poetic Terrorism." http://www.t0.or.at/hakimbey/taz/taz.htm (accesed February 24th 2009).

20» Bitzer, Jürgen and Philipp J. H. Schröder. The Economics of Open Source Software Development: Analyzing Motivation, Organization, Innovation and Competitions in the Open Source Software Revolution. Bingley: Emerald Group Publishing, 2006. 
21» Canniffe,Eamonn. "Neo-Rationalism: Aldo Rossi and the rediscovery of typology." In The Politics of the Piazza. Manchester: Ashgate Publishing Ltd., 2008.

22» Caughie, John. Theories of authorship: a reader. London: Routledge, 1985.

23» Cunningham, Ward, Bo Leuf. "WhatIsWiki". Wiki.org. http://wiki.org/wiki.cgi? WhatIsWiki (accessed April 16th, 2009).

24» Curtis, J. R. William. Modern Architecture Since 1900, third edition. London: Phaidon Press Limited, 2003.

25» Deek, Fadi P. and James A. McHugh. Open Source: technology and policy. New York: Cambridge University Press, 2008.

26»DiBona, Chris, Mark Stone and Danese Cooper. Open Sources 2.0: The Continuing Evolution. Sebastopol: O'Reilly, 2006.

27» Dmitri Bondarenko. "A Homoarchic Alternative to the Homoarchic State: Benin Kingdom of the 13th - 19th Centuries". Social Evolution \& History, Vol. 4, No 2 (2005), 18-88.

28》 Doubleday, Nancy. "Adaptive Co-management and the Learning that Leads to Social Innovation." The Open Source Business Resource, issue September 2008: Social Innovation (2008). http://www.osbr.ca/ojs/index.php/osbr/article/view/702/670 (accessed April 14, 2009).

29» Fink, Martin. The business and economics of Linux and Open Sour. New Jersey: Prentice Hall PTR, 2003.

30» Foucault, Michel. "What is an author?" In Textual Strategies: Perspectives in Poststructuralist Criticism, by Josué V. Harari. London: Routledge, 1980.

31» Foucault, Michel. "What is an Author?" translation Donald F. Bouchard and Sherry Simon. In Language, Counter-Memory, Practice. New York: Cornell University Press, 1977. 
32» Frampton, Kenneth. "Reflections on the Autonomy of Architecture: A Critique of Contemporary Production." In Out of Site: A Social Criticism of Architecture, by Diane Ghirardo, ed. Seattle: Bay Press, 1991.

33» Fuller, W. Robert. All rise: somebodies, nobodies, and the politics of dignity. San Francisco: Berrett-Koehler Publishers, 2006.

34» Gill, B., Richardson. The Great Maya Droughts: Water, Life, and Death. New Mexico: UNM Press, 2001.

35» Haralambidou, Penelope. "The Alegorical Project: Architecture as'Figurative Theory." In Architecture and Authorship, by Anstey, Tim, Grillner, Katja, and Rolf Hughes, eds. London: Black Dog Publishing Limited and the authors, 2007.

36» Hight, Christopher. "Scalar Networks, Super Creeps: Approaching the Non-Standard in the Architecture of Servo." In NetworkPractices, by Anthony Burke and Therese, Tierney, eds. New York: Princeton Architectural Press, 2007.

37» Holm, Ivar. "Ideas and beliefs in architecture and industrial design: how attitudes, orientations, and underlying assumptions shape built environment." Ph.D. Thesis. Oslo School of Architecture and Design, 2006.

38» Ingraham, Catherine. Architecture, Animal, Human: The Asymmetrical Condition. New York: Routledge, 2006.

39» Jones, Steve. Encyclopedia of New Media. New York: The Moschovitis Group, 2003.

40» Laplante, Phillip A. and Colin J. Neill. AntiPatterns: identification, refactoring, and management. Malvern: Auerbach Publications, 2006.

41» Kelly, Kevin. New Rules for the New Economy: 10 Radical Strategies for a Connected World. New York, Penguin, 1999.

42» Kelly, Kevin. "Better Than Free." The Technium. $h t t p: / / w w w . k k . o r g / t h e t e c h n i u m / a r c h i v e s / 2008 / 01 /$ better_than_fre.php (accessed April 13th, 2009). 
43» Keller, Sean. "Systems Aesthetics, or How Cambridge Solved Architecture." In Architecture and Authorship, by Anstey, Tim, Grillner, Katja, and Rolf Hughes, eds. London: Black Dog Publishing Limited, 2007.

44» Lavers, Annette. Roland Barthes, Structuralism and After: Structuralism and After. London: Taylor \& Francis, 1982.

45» Lipstadt, Helene. "Exoticising the Domestic: on New Collaborative Paradigms and Advanced Design Practices." In Architecture and Authorship, by Anstey, Tim, Grillner, Katja, and Rolf Hughes, eds. London: Black Dog Publishing Limited and the authors, 2007.

46» Martin, Louis. "Transpositions: On the Intellectual Origins of Tschumi's Architectural Theory." Assemblage, no. 11 (1990).

47» Mathews, Stanley. "Cedric Price as Anti-architect." In Architecture and Authorship, by Anstey, Tim, Grillner, Katja, and Rolf Hughes, eds. London: Black Dog Publishing Limited and the authors, 2007.

48» McCormack, Jon, Alan Dorin and Troy Innocent. 'Generative Design: a paradigm for design research.' Proceedings of Futureground by Redmond, J. et. al. (eds), vol.2, issuue1, 2004.

49» Meagher, E. Robert. “Techne.” Perspecta 24: The Yale Architectural Journal (1988): 158164.

50» Minnis, A.J. Medieval Theory of Authorship: Scholastic Literary Attitudes in the Later Middle Ages.London: Scolar Press, 1984.

51» Porter, Tom. Archispeak: an illustrated guide to architectural terms. London: Spoon Press, 2004.

52» Portugali, Juval. “Inter-representation Networks and cognitive mapping." In The construction of cognitive maps, by Juval Portugali, ed. Netherlands: Springer, 1996.

53» Powell, Kenneth. Richard Rogers. Complete Works, vol.1. London: Phaidon, 1999. 
54» Pramaggiore, Maria, and Tom Wallis. Film: A Critical Introduction. China: Laurence King Publishing, 2005.

55» Prof. Dr. Evers, Bernd and Christof Thoenes. Architectural theory. Berlin: Taschen, 2003.

56» Price, Cedric, Arata Isozaki, Patrick Keiller and Hans-Ulrich Obrist. RE: CP. Basel: Birkhauser Verlag AG, 2003.

57» Sadler, Simon, Archigram (Group). Archigram: Architecture Without Architecture. Cambridge, MA: MIT Press, 2005.

58» Sennet, Richard. The Craftsman. New Haven \& London: Yale University Press, 2008.

59» Aristotle. "Metaphysics" trans. by Hugh Tredennick. Aristotle in 23 Volumes, Vols.17, 18. Cambridge, MA: Harvard University Press, 1934.

60» Speaks, Michael. "Two Stories for the Avant-garde II." In Architab. Radical Experiments in Global Architecture, by Migayrou and Brayer, eds. London: Themes\&Hudson, 2001. Also at http://www.archilab.org/public/2000/catalog/speaksen.htm (accesed: April 11th, 2009).

61» Stallman, M. Richard. Free Software, Free Societies, ed. by Joshua Gay. Boston: GNU Press, 2002.

62» Tierney, Therese. "Biological Networks: On Neurons, Cellular Automata, and Relational Architectures." In Network Practices, by Anthony Burke and Therese, Tierney eds. New York: Princeton Architectural Press, 2007.

63» Van Dijk, Hans. "Architecture and Legitimacy. Styles and Strategies." In Architecture and Legitimacy, by Hans van Dijk and Liesbeth Janson eds., transl. by D'Lane Camp and Donna de Vies-Hermansader. Rotterdam: NAi, 1995.

64» Weber, Steve. The success of Open Source. USA: Harvard University Press, 2004.

65» Wigley, Mark. “The Architectural Brain." In Network Practices, by Anthony Burke and Therese, Tierney, eds. New York: Princeton Architectural Press, 2007. 
66»Woods, Lebbeus. "The Question of Space." In Technoscience and Cyberculture, by Stanley Aronowitz, B. Martinsons, and M. Menser, eds., 279-292. New York: Routledge, 1996. 